УДК 656.212.7

\title{
ДОСЛІДЖЕННЯ СЕЗОННОЇ НЕРІВНОМІРНОСТІ ПЕРЕВЕЗЕНЬ ВАНТАЖІВ ТА ЇЇ ВПЛИВ НА ОРГАНІЗАЦІЮ МІСЦЕВОЇ РОБОТИ ДІЛЬНИЦЬ
}

К-т техн. наук О.М. Костснніков, магістранти Чудна О.Л., Барскова А.Ю.

\section{ИССЛЕДОВАНИЕ СЕЗОННОЙ НЕРАВНОМЕРНОСТИ ПЕРЕВОЗОК ГРУЗОВ ТА ЕЁ ВЛИЯНИЕ НА ОРГАНИЗАЦИЮ МЕСТНОЙ РАБОТЫ УЧАСТКОВ}

\author{
К-т техн. наук А.М. Костенников, магистранты Чудная О.Л., Барскова А.Ю. \\ RESEARCHING SEASONAL FLUCTUATIONS CARGO ITS IMPACT ON THE \\ ORGANIZATION OF LOCAL SITE WORKS
}

Cand. of techn. sciences. O.M. Kostennikov, master student Chudna O.L., Barskova A.Y.

Майже половина всієї вантажної роботи виконується на проміжних станціях, більшість з яких обслуговуються збірними поӥздами. Упорядкування роботи ичих поїдів $\epsilon$ однією з найважливіших умов удосконалення організації місцевих вагонопотоків $і$ повинно проводитися на основі твердого графіку руху поӥздів. 3 урахуванням зазначеного в статті проведено дослідження питання формування місиевих поїздів в умовах нерівномірності.

Ключові слова: вагонопотік, вантажні поїди, місиева робота, доставка вантажу, нерівномірність перевезень.

Почти половина всей грузовой работы выполняется на промежуточных станциях , большинство из которых обслужсиваются сборными поездами. Составление работы этих поездов является одной из важнейших условий совершенствования организачии местных вагонопотоков и должно проводиться на основе твердого графика движения поездов . C учетом указанного в статье проведено исследование вопроса формирования местных поездов в условиях неравномерности.

Ключевые слова: вагонопоток, грузовые поезда, местная работа, доставка груза, неравномерность перевозок.

A basic task of the system of organization of local work is providing of efficiency of a transport conveyer in the conditions of unevenness of traffic volumes with the purpose of reduction of time of turn of local carriage, reduction of outage of technical equipments and human capitals on handling fronts, perfection of co-operating with other types of transport and major concerns, and also the rational use of locomotives and carriages. Almost the half of all freight work is executed on the intermediate stations, majority from that served by collapsible by train. Drafting of work of these trains is one of major terms of perfection of organization of local traffic volumes and must be conducted on the basis of hard train table. Taking into account indicated in the article a study of question of forming of accommodation trains is undertaken in the conditions of unevenness.

Key words: traffic volumes, freight trains, local work, delivery of cargo, uneven traffic.

Вступ і постановка проблеми у загальному вигляді та її зв'язок із важливими науковими та практичними завданнями. Основна задача системи організації місцевої роботи - забезпечення ефективності транспортного конвеєра в умовах нерівномірності вагонопотоків 3 метою зменшення часу обороту місцевого вагону, скорочення простою технічних засобів і людських ресурсів на вантажнорозвантажувальних фронтах, удосконалення взаємодії 3 іншими видами транспорту та великими підприємствами, а також раціонального використання локомотивів $\mathrm{i}$ вагонів [2,3].

Визначення мети та задачі дослідження. Основним напрямком згідно Транспортної стратегії України є комплексна 
оптимізація роботи залізниць України, що спрямована на підвищення ефективності якості експлуатаційної роботи на базі нової системи управління перевезеннями. Падіння обсягів перевізної роботи на залізничному транспорті зумовило значний розрив між фактичними та потрібними ресурсами [12]. Майже половина всієї вантажної роботи виконується на проміжних станціях, більшість 3 яких обслуговуються збірними поїздами. Упорядкування роботи цих поїздів $\epsilon$ однією 3 найважливіших умов удосконалення організації місцевих вагонопотоків і повинно проводитися на основі твердого графіку руху поїздів [5]. 3 урахуванням зазначеного виникає необхідність в дослідженні питання формування місцевих поїздів в умовах нерівномірності.

Аналіз останніх досліджень. У різні періоди роботи залізничного транспорту вчені, інженери, передовики виробництва зробили значний внесок в області теоретичних розробок, пов'язаних 3 раціональною організацією місцевої роботи дільниць, внесли багато корисних теоретичних і практичних пропозицій щодо покращення i удосконалення процесу місцевих перевезень [7,2,3,4,10]. Але через нерівномірність перевезень організація місцевих вагонопотоків потребує більш оперативного реагування, що визначило необхідність більш детального дослідження даного питання.

Основна частина дослідження. Залізничному транспорту, як і транспорту взагалі, притаманні постійні коливання обсягів перевізної роботи.

Під коливаннями обсягів перевізної роботи мається на увазі:

- зміна кількості відправлених вантажів із навантажувальних районів за сезонами року;

- зменшення навантаження в вихідні дні;

- припинення

розвантажувальних робіт підприємствами в нічний час;

- добові коливання

вагонопотоків та розмірів руху;
- згущення підводу поїздів до стикових пунктів переходу з залізниці на залізницю і т.д.

Перераховані вище коливання відбуваються в часі, тому їх прийнято називати нерівномірністю залізничних перевезень у часі $[11,1]$.

Нерівномірність перевезень в часі призводить до значного погіршення використання рухомого складу, непродуктивного використання локомотивів та надпростою місцевих вагонів на залізничних станціях. Як правило, нерівномірність в вантажній роботі впливає на експлуатаційну роботу мережі, залізниць, дирекцій, напрямків (збільшуються простої вагонів під вантажними операціями, в очікуванні відправлення та на технічних станціях; зростає оборот та збільшується робочий парк вагонів). В періоди зменшення вантажної роботи, можуть не виконуватися норми передачі вагонів по стиковим пунктам; збільшується відсоток порожнього пробігу вагонів; погіршується використання локомотивного парку; порушується нормальний режим роботи та збільшується необхідність в локомотивних бригадах [8].

Коливання розмірів вантажної роботи та поїзного руху викликано значною кількістю причин, які можна класифікувати наступним чином:

- причини, які залежать від експлуатаційних вимог роботи залізничного транспорту;

- причини, які пов'язані 3 сезонними факторами;

- причини, що знаходяться за межами транспорту, які можна прогнозувати та враховувати при плануванні перевезень;

- причини, що знаходяться за межами транспорту, більшість 3 яких не піддається будь-якому точному обліку.

Друга та четверта причини переважно впливають на обсяги перевезень за тривалими періодами - сезон, місяць; третя причина - в основному викликає добову нерівномірність. Згущення роботи в окремі періоди доби, як правило, визначаються першою групою. 3 цієї ж причини виникає внутрішньонедільна нерівномірність, яка 
пов'язана 3 перервами в виробництві продукції в вихідні та святкові дні.

У зв'язку з тим, що внутрішньодобова та внутрішньонедільна нерівномірність навантаження є наслідком технологічних та організаційних проблем, iï можна не враховувати при створенні резервів на нерівномірність. Отже, в дослідженні інтерес представляють сезонна

та внутрішньомісячна нерівномірність. Безперечно, що всі нерівномірності мають деякий технологічний вплив, але таке представлення нерівномірності полегшить проведення аналізу впливу коливань обсягів роботи на організацію місцевих вагонопотоків.

Зміна обсягів перевезень за періодами року (квартал, місяць) прийнято називати сезонною нерівномірністю. Сезонну нерівномірність перевезень найбільш точно визначати коливаннями обсягів навантаження. Нерівномірність відправлення вантажів породжує нерівномірність виробництва та нерівномірність підходу порожніх вагонів під навантаження, яка залежить від характеру вивільнення вагонів в місцях вивантаження, що в свою чергу знаходиться під впливом нерівномірності відправлення вантажів. Тим самим виникає коло, в якому, один раз виникає, а потім циркулює нерівномірність.

Таким чином, нерівномірність перевезень, або постійні коливання обсягів роботи транспорту по навантаженню та руху, $\epsilon$ специфічною особливістю залізничного транспорту, яку необхідно враховувати при плануванні перевезень, розвитку технічних засобів та організації перевізного процесу.

Статистичне дослідження сезонності пропонується проводити в «статичному» та в «динамічному» аспектах. Статичний аналіз сезонності ставить наступні задачі: чисельно виразити прояви сезонних коливань; виявити їх потужність та характер в конкретних умовах; відкрити фактори, що викликають сезонні коливання; провести математичне моделювання сезонної хвилі. Ціллю динамічного аналізу $\epsilon$ вивчення закономірностей формування сезонних хвиль об'ємних показників вантажних перевезень та висновок про їх еволюцію в часі (на протязі декількох років).

Відомо декілька способів дослідження сезонних коливань. Найбільш простим $\epsilon$ побудова індексів сезонності $[9,13]$. Індексами сезонності $є$ показники, які характеризують результати порівняння фактичних рівнів даного місяця із середньомісячним рівнем або рівнями, що розраховані при виявленні основної тенденції для того ж місяця.

Найбільш точним способом розрахунку індексу сезонності $є$ розрахунок сезонних коливань за допомогою згладжування ряду за методом ковзної середньої. В цьому випадку індекси сезонності розраховуються як відношення фактичного рівня відповідного місяця до згладженого рівня. Після встановлення стійких коливань можна перейти до моделювання сезонної хвилі. Моделювання сезонної хвилі виконується на основі побудови аналітичної залежності сезонних коливань. Побудова аналітичної моделі виявляє основний закон коливання даного часового ряду у зв'язку з переходом від місяця до місяця та дає середню характеристику внутрішньорічних коливань.

В якості аналітичної форми сезонної хвилі показників вантажних перевезень пропонується використовувати рівняння, що являє собою кінцевий ряд (ряд Фур'є) синусоїдальних членів 3 косинусами та синусами, та має назву гармонічного аналізу. Синусоїдальна або косинусоїдальна функція 3 визначеним періодом i $\epsilon$ гармонікою. Кожен член суми представляє 3 себе гармоніку 3 визначеним періодом. Перша гармоніка має період, який дорівнює довжині періоду, що досліджується. Друга має період, який дорівнює половині основного, третя одній третині основного та iн. В загальному вигляді якщо $є \quad p$ спостережень, то число гармонік не повинно перевищувати $p / 2$.

Якщо величину показника, який досліджується, представити як частину довжини кола, то залежність відповідних їм значень показника буде мати наступний вигляд 


$$
\bar{y}_{t}=a_{0}+\sum_{i=1}^{p / 2}\left[A_{i} \sin (2 \pi * i t / p)+B_{i} \cos (2 \pi * i t / p)\right]
$$

(1)

де $p$ - число значень показника, що вивчається або величина періоду;

$i$ - величина гармоніки;

$t$ - номер спостереження $(t=1,2 \ldots, p)$;

$a_{0}$ - середньорічний рівень показника;

$A_{i}, B_{i}$ - коефіцієнти гармонік.

Представлення часового ряду у вигляді рівняння (1) відомо як гармонічний регресійний аналіз.

Коефіцієнти $A_{i}, B_{i}$ оцінюються по методу найменших квадратів. Отримання формул для коефіцієнтів визначається завдяки властивості ортогональності

$$
\begin{aligned}
& \sum_{i=1}^{p} \sin (2 \pi * i t / p) \sin (2 \pi * j t / p)\left\{\begin{array}{l}
=0, \text { якщуо } i \neq j \\
=0, \text { якщзо } i=j=0 \neq p / 2 \\
=p / 2, \text { якщзо } i=j \neq 0 \neq p / 2
\end{array}\right. \\
& \sum_{t=1}^{p} \cos (2 \pi * i t / p) \cos (2 \pi * j t / p)\left\{\begin{array}{l}
=0, \text { якщзо } i \neq j \\
=p / 2, \text { якщзо } i=j \neq 0 \neq p / 2 \\
=p, \text { якщุо } i=j=0
\end{array}\right. \\
& \sum_{t=1}^{p} \cos (2 \pi * i t / p) \sin (2 \pi * j t / p)=0 \quad \text { якщуо } i=j=0,1,2 \ldots, p / 2
\end{aligned}
$$

Для оцінки параметрів $a_{0}, A_{i}, B_{i}$ рівняння (1) при парному числі спостережень використовуються наступні формули

$$
\begin{gathered}
a_{0}=\left(\sum_{t=1}^{p} y_{t}\right) / p \\
A_{i}=2\left[\sum_{t=1}^{p} \sin (2 \pi * i t / p)\right] / p \\
B_{i}=2\left[\sum_{t=1}^{p} \cos (2 \pi * i t / p)\right] / p
\end{gathered}
$$

Звідси видно, що $a_{0} \epsilon$ середнє значення показника за період. Число гармонік не може перевищувати $p / 2$, тобто $i \leq p / 2$. Тому за цими формулами необхідно розраховувати коефіцієнти для $(p / 2-1)$ гармонік. Для останньої гармоніки завжди:

$$
\begin{gathered}
A=0 \\
B=2\left[\sum_{t=1}^{p} \cos (2 \pi * i t / p)\right] / p
\end{gathered}
$$

Для отримання узагальненої характеристики потужності коливань динамічного ряду із-за сезонного фактору пропонується використовувати середнє квадратичне відхилення індексів сезонності (у \%) від 100\% або коефіцієнт коливання сезонної хвилі.

$$
\sigma_{c е з}=\sqrt{\sum\left(i_{c e s}-100\right)^{2} / 12},
$$

де $i_{\text {сез }}$ - значення постійної сезонної хвилі у \% (індекс сезонності).

Порівняння коефіцієнтів коливання, які розраховуються за різні періоди, вказує зміщення в сезонності. Зменшення $\sigma_{\text {сез }}$ вказує зниження впливу сезонності на динаміку показника, що аналізується.

Зрушення в сезонності призводять до еволюції сезонної хвилі, яку можливо оцінювати за допомогою коефіцієнтна напруженості Н.С. Четвертікова.

Коефіцієнт напруженості характеризує зв'язок між абсолютними сезонними відхиленнями та постійною сезонною хвилею. Цей зв'язок записується рівнянням прямої для кожного періоду:

$$
d=R^{*} y,
$$

де $R$ - коефіцієнт напруженості для відповідного періоду; 
$y$ - постійна сезонна хвиля в нормованих відхиленнях, яка розраховується за значеннями:

$$
t_{i}=d_{i} / \sigma_{i}
$$

де $\sigma_{i}$ середнє квадратичне відхилення абсолютних сезонних коливань.

Зміна коефіцієнта напруженості по рокам вказує на еволюцію сезонних коливань, i, як наслідок, сезонної хвилі.

Розрахунок сезонної хвилі об' ємних показників вантажних перевезень пропонується виконувати в наступній послідовності: тренд, сезонні коливання, сезонна хвиля. Використання даного принципу основане на гіпотезі одностороннього зв'язку між трендом та сезонною хвилею. Від правильного тренда залежить точність сезонної хвилі. Щоб максимально виключити тенденцію 3 динамічного ряду, необхідно часовий тренд та сезонний компонент розрахувати за два ітераційних етапи.

\section{Для}

компоненту використовувати ітеративний метод. Використання даного методу засноване на принципі послідовного та комплексного розрахунку загальної тенденції та сезонної хвилі. За допомогою цього методу розраховується попередня та кінцева розрахункова хвиля, в якій найбільш повно еліміновано вплив тренда та випадкових коливань [8].

Для більш обгрунтованого формулювання вимог нерівномірності був проведений аналіз обсягів місцевої роботи 3 урахуванням нерівномірності перевезень.

Аналіз фактично виконаних обсягів роботи залізниць проводився на основі звітних даних ГО-2, ГО-10, ЦО-11.

Дослідження внутрішньорічних коливань навантаження всіх вантажів проводилося за 2011-2013 роки. Для виключення основної тенденції розвитку динамічного ряду, яка суттєво змінювала стійкі внутрішньорічні коливання, використовувалась 12-місячна та 7-місячна ковзна середня в два ітераційних етапи.
Після видалення тренду розраховувались сезонні коливання в нормованих відхиленнях. Після цього будувалася сезонна хвиля в нормованих відхиленнях. Для традиційності представлення сезонної хвилі, нормовані відхилення перераховані в індекси сезонності. Оцінка ступені еволюції сезонної хвилі виконувалась за допомогою коефіцієнта напруженості, сила коливання постійної сезонної хвилі за допомогою коефіцієнта коливання.

На рис. 1 показано відношення обсягу середньодобового навантаження вагонів по всіх залізницях УЗ за місяць до середньодобового обсягу навантаження за рік.

3 діаграми видно, що обсяги перевезення вантажів за місяцями перевищують середньорічний обсяг перевезення, наприклад, в листопаді майже на $25 \%$. Проведене дослідження сезонної нерівномірності навантаження вантажів вказує на те, що постійні сезонні хвилі мають стійкий характер. За досліджуваний період коефіцієнт напруженості не мав тенденції до значної зміни.

Вищенаведені дані вказують на наявність вагомих відмінностей в організації місцевої роботи в умовах сезонного коливання вагонопотоків.

Для врахування цих відмінностей необхідно більш повно використовувати математичний апарат для моделювання технології роботи на ЕОМ і вирішення задач в оперативних умовах [14]. Об'єктом автоматизації повинен бути процес підготовки рішень по змінно-добовому i поточному плануванні та управлінні місцевою роботою залізниці і iї дирекцій на основі інформаційної бази автоматизованих систем (АСУ) лінійного і дорожнього рівнів.

Висновки 3 дослідження i перспективи, подальший розвиток у даному напрямку. На протязі останніх декількох років спостерігається збільшення перевезень вантажів, але при збільшенні перевезень не спостерігається збільшення частки маршрутизації. Ці два фактори призводять до зростання вагонопотоку, який перероблюється на 
технічних станціях, що підвищує простої вагонів i оборот вагона, збільшуючи в свою чергу робочий парк. При нерівномірності перевезення вантажів для переробки збільшеного вагонопотоку, необхідно створювати додаткові та розвивати існуючі станції, що призведе до значних капітальних витрат. Уникнути значних інвестицій в розвиток залізничної інфраструктури при зменшенні обороту вагона та експлуатаційних витрат можливо за рахунок збільшення частки маршрутизації, особливо ступінчатої, адже навантаження вантажів розосереджено по багатьох станціях дільниці. Отже, виникає необхідність створення системи, що визначатиме оптимальні регулювальні заходи щодо раціональної підв'язки локомотивів під місцеві состави для формування збірних та вивізних поїздів, ступінчатих маршрутів, призначення диспетчерських локомотивів в умовах сезонного коливання вантажопотоків.

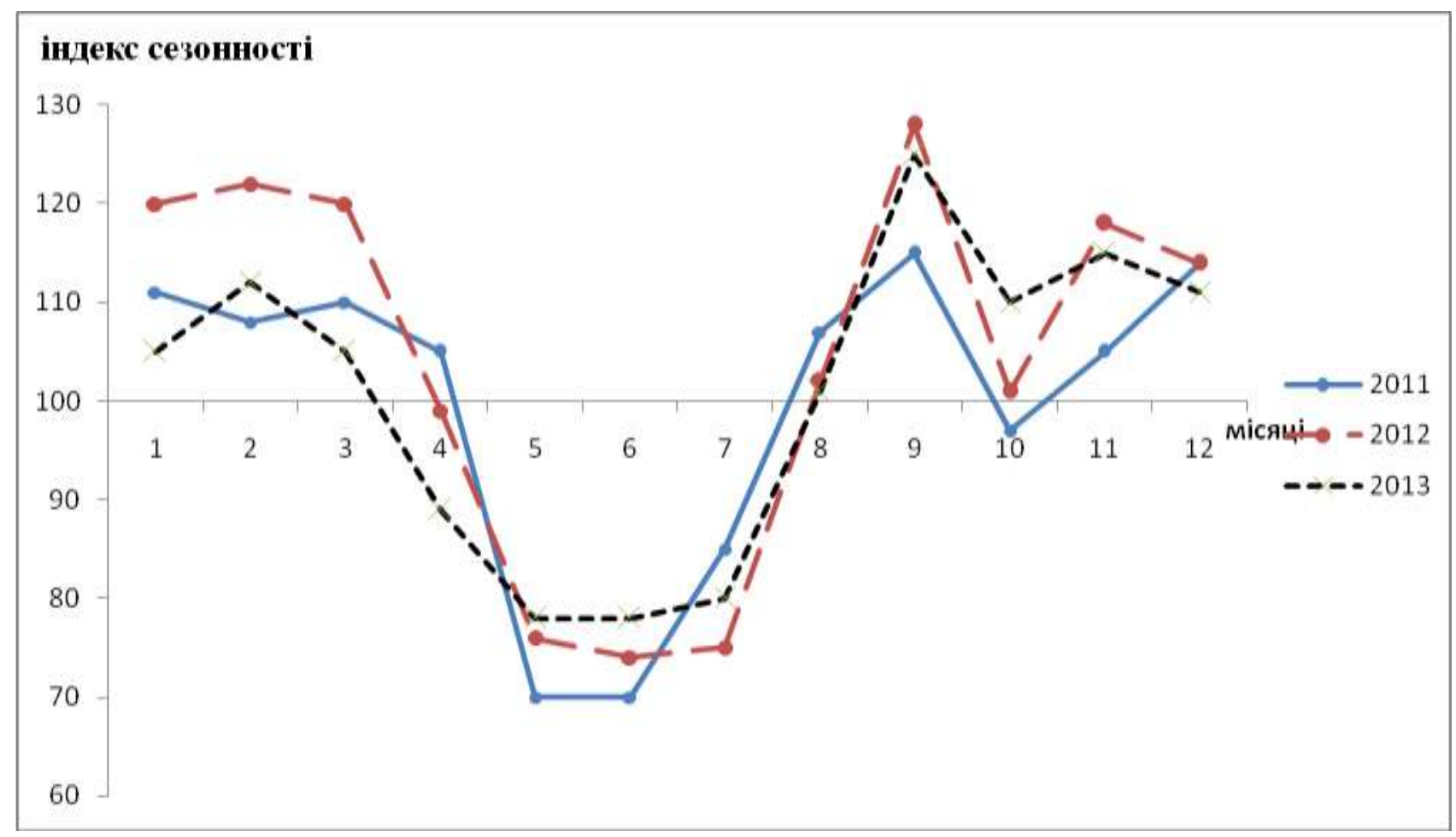

Рисунок 1 - Індекс сезонності навантаження вантажів за 2011-2013 рр

\section{Список використаних джерел}

1 Барков, Н.Н. Сезонная и внутринедельная неравномерность грузовых перевозок на железных дорогах [Текст] / Н.Н Барков. - М.:Трансжелдориздат, 1963. - 96с.

2 Гильденгорн, И.А. Совершенствование организации местной работы отделения дороги на основе математического моделирования [Текст] / И.А. Гильденгорн // Тр. ВНИИЖТ. - 1987. - Вып. 2. - С. 7-11.

3 Гришин, А.П. Местная работа отделения: опыт и проблемы [Текст] / А.П.Гришин // Железнодорожный транспорт. - 1996. - №2. - С. 10-20.

4 Данько, М.І. Прогнозування розподілу вагонопотоків на основі теорії нечітких множин [Текст] / M.I. Данько, О.В. Лаврухін // Інформаційно-керуючі системи на залізничному транспорті. - 2004. - №2. - С. 80-83.

5 Кирьянова, О.С. Выбор рационального числа остановок сборных поездов [Текст] / О.С. Кирьянова // Вестник ВНИИЖТ. - 1964. - №5. С. 16-22.

6 Костєнніков, О.М. Удосконалення технології регулювання рухомого складу для перевезення сезонних вантажів [Текст] / О.М. Костєнніков, В.М. Запара, Д.І. Мкртичьян, 
А.О. Ковальов, М.В. Кузьменко // Збірник наук. праць. - Харків: УкрДАЗТ, 2010. - Вип. 112. - C. 123-128.

7 Лаврухін, О.В. Удосконалення автоматизованих робочих місць оперативного персоналу на базі інформаційно-керуючих систем [Текст] / О.В. Лаврухін, І.В. Мікулін // Збірник наук. праць. -Харків: УкрДАЗТ, 2007. -Вип. 85. - 70-78 с.

8 Мацюк, В.І. Удосконалення системи розвозу місцевих вагонів в залізничному вузлі: автореферат дис. ... канд. техн. наук: 05.22.01 / В.І. Мацюк; [ДЕТУТ]. - К., 2008. $22 \mathrm{c}$.

9 Прилепин, Е.В. Методы оперативного управления доставкой местного груза на отделении железной дороги: автореферат дис. ... канд. техн. наук: 05.22 .08 / Е.В. Прилепин, [ВНИИАС МПС России]. - М., 2004. - 22с.

10 Сафиулин, Р.Н. Совершенствование управления местной работой / Р.Н. Сафиулин [Текст] // Сб.науч.трудов. УрГУПС. - 2006. - №52. - С. 13-19.

11 Ситников, М.Д. Неравномерность перевозок грузов и резервы вагонного парка [Текст] / М.Д. Ситников. - М.: Транспорт, 1968. - 142 с.

12 Транспортна стратегія України на період до 2020 року. [Електронний ресурс]: [схвалена розпорядженням КМУ від 16.груд. 2009p. №1555-p.]. -Режим доступу: www/URL: http://www.mintrans.gov.ua/ uk/discussion/15621.html/ 10.12.2009. - Київ.

13 Федотов, Н.И. Колебания объемов работы на грузовых станциях [Текст] / Н.И. Федотов. - Труды НИИЖТ. - Вып. 39. - 1964. - С. 53-76.

14 Швыров, В.В. Сезонные колебания в торговле и методы их изучения [Текст] / В.В. Швыров, Т.С. Швырова. - Новосибирск, 1969. - 41 с.

Рецензент д-р техн. наук, професор О.М.Огар

Костєнніков Олексій Михайлович к-m техн. наук, доцент кафедри Управління вантажною $i$ комериійною роботою. Тел.: 057-730-19-89, e-mail: alexeykostennikov@yandex.ru

Чудна Ольга Леонідівна слухач групи МЗ-ОПУТ-13

Барскова Анна Юрї̈вна слухач групи МЗ-ОПУТ-13

Kostennikov Olexiy Mikhaylovich Ph. D, associate professor of the chair "Management of freight and commercial operation”. Tel.:057-19-89, e-mail: alexeykostennikov@yandex.ru

Chudna Olga Leonidivna. student of the group M3-ROM-13

Barskova Anna Yuriivna student of the group M3-ROM-13

УДК 625.162:656.2.08

АНАЛІЗ АВАРІЙНОСТІ НА ЗАЛІЗНИЧНИХ ПЕРЁ̈ЗДАХ

Магістрант Каліберда М.В.

АНАЛИЗ АВАРИЙНОСТИ НА ЖЕЛЕЗНОДОРОЖНЫХ ПЕРЕЕЗДАХ

Магистрант Калиберда Н.В.

THE ANALYSIS OF ACCIDENTS ON RAILWAY CROSSINGS.

master student Kaliberda N.V.

Значна кількість дорожньо-транспортних пригод на залізничних переїздах, кількість жертв від них, та матеріальні збитки, змушують звертати велику увагу на ці питання, розробляти нові підходи до їх вирімення, впроваджувати нові схеми та системи запобігання циим явищам. Це є одним із пріоритетних напрямків в підвищенні безпеки на залізничному транспорті. 
Ключові слова: залізничний транспорт, залізничні переїзди, безпека руху, дорожньотранспортні пригоди ,аналіз,варіанти вирішень .

Большое количество дорожно-транспортных происшествий на железнодорожных переездах, количество жертв от них, и финансовые убытки, заставляют уделять много внимания этому вопросу, разрабатывать новые подходы к ее решению, вводить новые схемы и системы предотвращения этих явлений. Это является одним из приоритетных направлений, в повышении безопасности движения на железнодорожном транспорте.

Ключевые слова: железные дороги, железнодорожные переезды,безопасность движения, анализ, варианты решений.

Plenty of accidents on railway moves, amount of victims from them, and financial losses, compel to spare much attention on this problem, work out new going near its decision, to enter new charts and systems of prevention of these phenomena. This is a priority way, in the increase of safety of motion on the rail road.

Keywords: Ukrainian railways, railroad moves, accidents, safety of motion, analysis, solutions.

Вступ і постановка проблеми у загальному вигляді та її зв'язок із важливими науковими та практичними завданнями. Однією 3 актуальних проблем забезпечення безпеки залізничного руху $\epsilon$ травматизм на залізничних переїздах. Серед місць зосередження випадків травматизму на залізничному транспорті лідирують залізничні переїзди. 3 ціллю підвищення безпеки на залізницях України та закордоном розробляються та широко застосовуються різні організаційні, профілактичні та технічні заходи, реалізація яких, вимагає великих капітальних вкладень та не завжди призводить до очікуваних результатів [8]. Чим нижче ризик виникнення аварії, тим більше приходиться платити за кожну одиницю його подальшого зменшення. Тому, в ряді випадків, подальше підвищення рівня безпеки пов 'язано 3 дуже великими додатковими витратами [10]. Задача пошуку обгрунтованих рішень по забезпеченню безпеки при управлінні технологічними процесами на залізничному транспорті відноситься до класу багатокритеріальних, дуже складних, слабкоструктурованних, а в ряді випадків, як задачі, що не підлягають формалізації.

Визначення мети та задачі дослідження. Провести аналіз безпеки руху на залізничних переїздах, та визначити можливі варіанти зменшення аварійності у місцях перетину залізничного та автомобільного транспорту.

Аналіз останніх досліджень. Проблема забезпечення безпеки на залізничному транспорті актуальна для більшості країн, які мають розвинену мережу залізниць. Аналіз публікацій показує, що на залізницях всього світу щорічно трапляються тисячі аварій, в результаті яких, вмирають чи отримують травми різного ступеня складності декілька тисяч людей $[1,2,3,5,7]$.

Основна частина дослідження. Аварії на залізничних переїздах завдають значні матеріальні збитки в результаті пошкодження залізничного полотна, контактної мережі, рухомого складу, простою поїздів та зриву графіку руху, що призводять до несвоєчасної доставки вантажів та пасажирів [5]. На рисунку 1 наведено інформацію щодо кількості транспортних подій на залізничних переїздах залізниць України.

3 діаграми кількості транспортних подій слідує, що у 2011 трапилось 66 транспортних пригод на залізничних переїздах, це на 2 випадки менше ніж за 2012 рік (кількість дорожньо-транспортних пригод складає 68), а в 2013 році, тенденція 3 дорожньо-транспортних пригод зменшилась на 1 подію (65 випадків), порівняно з 2011 роком, та на 3 
(68 випадків) порівняно з 2012. У 2014 році, тенденція 3 дорожньо-транспортними пригодами продовжила зменшуватись, та склала 56 випадків. Це на 10 випадків менше ніж в 11-му році, на 12 менше ніж у 12-му та на 9 менше ніж у 13-му [1]. Не зважаючи на щорічне зменшення кількості транспортних подій ми бачимо, що $\epsilon$ резерви для зменшення цього показника. На рисунку 2 наведено інформацію щодо кількості загиблих на залізничних переїздах залізниць України.

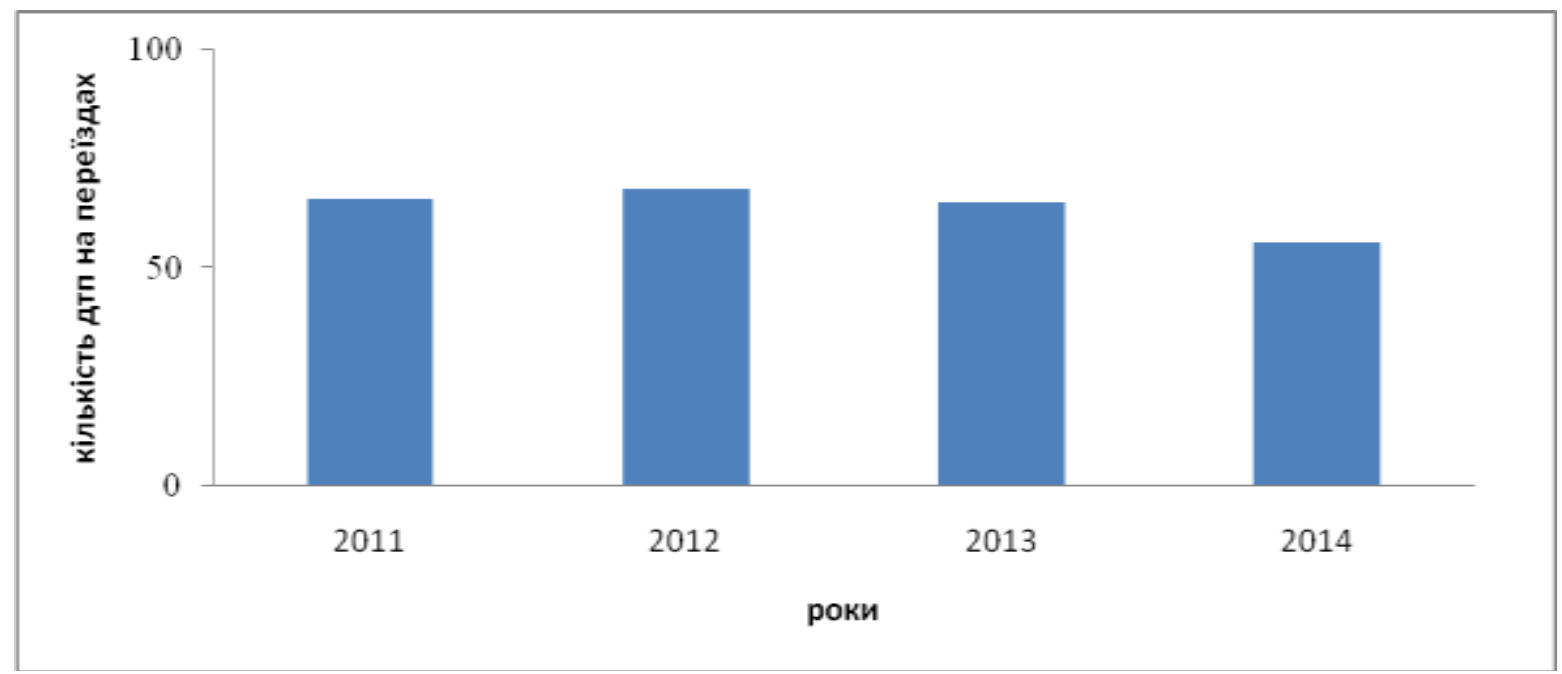

Рисунок 1 - Діаграма кількості транспортних подій на переїздах України з 2011 2014pp.

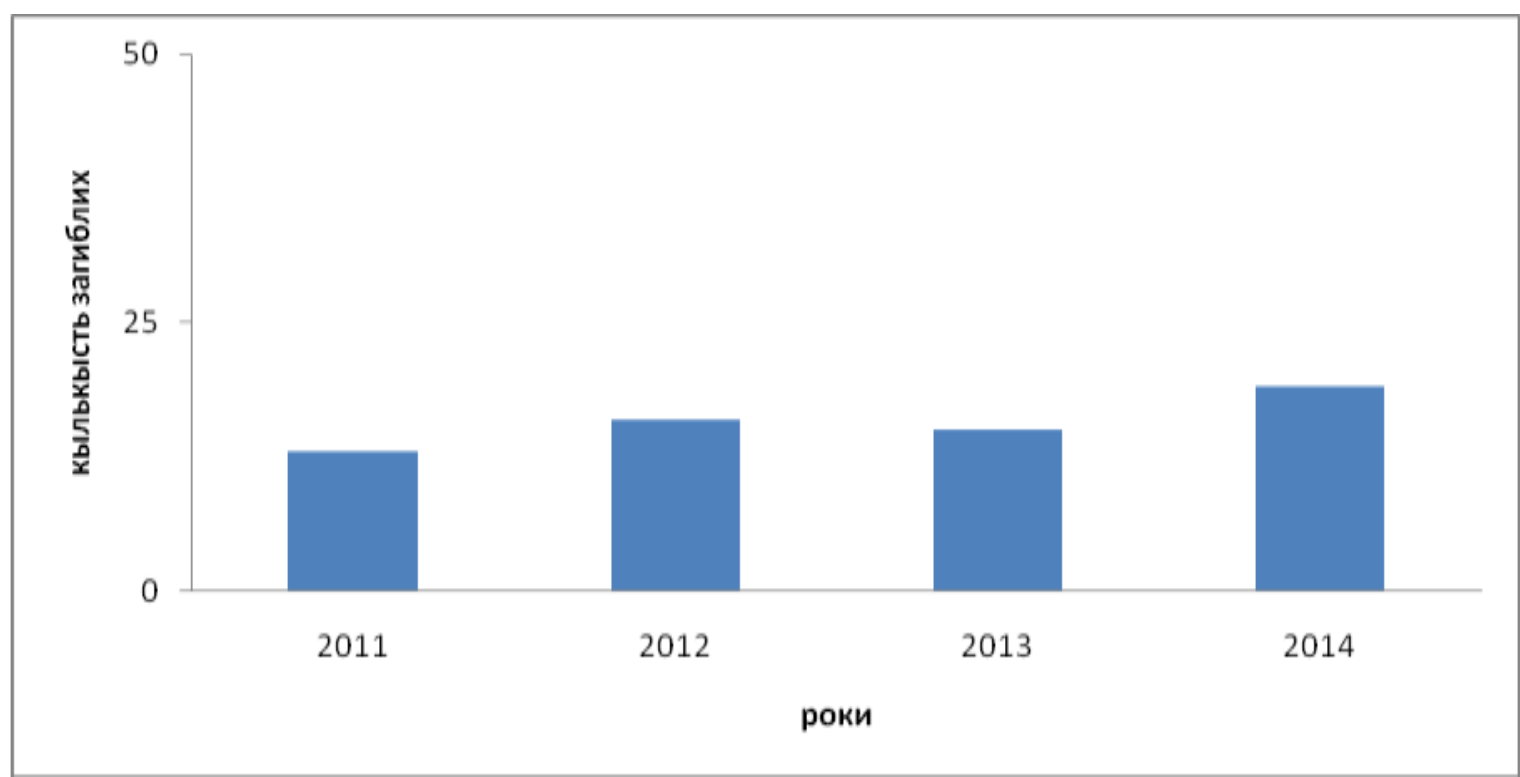

Рисунок 2 - Діаграма кількості загиблих у наслідок дорожньо-транспортних подій на переїздах з 2011 - 2014pp.

3 діаграми кількості загиблих у наслідок дорожньо-транспортних подій на переїздах з 2011 - 2014pp видно, що кількість жертв аварій на переїздах у 2011му -13 загиблих, у 2012 - 16 загиблих, це на 3 більше ніж в 11-му, у 2013-му - 15 загиблих, це на 1-го менше ніж у 2012, та на 2 більше ніж у 11-му році, у 2014-му число загиблих склало 19 осіб - це на 6 більше ніж в 11-му році, на 3 більше ніж у 12-му році та на 4 більше ніж у 2013 році. Тенденція 3 жертвами, на протязі цього періоду погіршилась [1].

Шляхи вирішення даної проблеми розглядаються в Положенні галузевої програми Укрзалізниці з підвищення безпеки руху на залізничних переїздах на 2011-2015 роки [4]. Основні з них:

1. Будівництво за маршрутами руху швидкісних поїздів нових шляхопроводів, 
замість існуючих переїздів. Особливо в найбільш густо населених місцях, де спостерігається масове перетинання автомобільних потоків із залізницями.

2. Впровадження технологій, які зроблять повністю неможливим проїзд автотранспорту на переїзд при заборонному показанні дорожнього світлофора. Маються на увазі так звані бар'єрні установки. Вони являють собою спеціальні металеві листи, які піднімаються під кутом перед автомобілем на висоту $40 \mathrm{~cm}$, блокуючи виїзд. На сьогодні вже змонтовано кілька таких установок: на перегоні Мелітополь Обільна Придніпровської залізниці, Ірпінь Буча Південно-Західної залізниці, на Львівській залізниці та по дві одиниці в Харківській і Вінницькій областях.

3. Перекриття проїжджої частини переїздів за допомогою чотирьох шлагбаумів.
4. Посилення взаємодії Укрзалізниці з підрозділами ДАІ щодо контролю за дотриманням правил дорожнього руху на переїздах.

5. Розробка та розповсюдження програм навчальних курсів для дітей про правила безпеки на залізницях.

Висновки 3 дослідження і перспективи, подальший розвиток у даному напрямку. Залізничні переїзди $\epsilon$ місцем підвищеної небезпеки, де щорічно відбувається велика кількість дорожньотранспортних пригод, що характеризуються значними людськими жертвами, особливо важким травматизмом, та суттєвими матеріальними збитками. Питання забезпечення безпеки руху на переїздах актуальна i на сьогодні та має важливе значення і потребує більш детального розгляду та удосконалення за рахунок використання сучасних формаційних систем.

\section{Список використаних джерел}

1. Віртуальний прес-центр Укрзалізниці. [Електр. ресурс]. Режим доступа http://www.magistral-uz.com.ua

2. Чикин, В.Н. Железнодорожные переезды: что показывает статистика [Текст] / В.Н. Чикин, В.А. Поздняков, Ю.А. Тюпкин // железнодорожный транспорт. - 2002.-№9-С.34-36.

3. Бойник, А. В. Пути повышения безопасности на железнодорожных переездах [Текст] / А. В. Бой- ник, А. А. Абакумов // Інформ.-керуючі системи на залізн. трансп. - 2007. - № 4. - С. 90-95.

4. Сидоренко, Г. Г. Безпека руху на залізничних переїздах гарантія екологічної стабільності [Текст] / Г. Г. Сидоренко // Проблеми та перспективи розвит- ку залізничного транспорту : 74 Міжнар. науково- пр. конф. - Дніпропетровськ: ДНУЗТ, 2014. - С. 357-358

5. Чикин, В.Н. Повышение безопасности движения на переїздах [Текст] / В.Н. Чикин, В.А. Поздняков, В.В. Никитин, Ю.А. Тюпкин // Залізничний транспорт.- 1999.-№5.-С.54-57.

6. Чикин, В.Н. Переездам - особое внимание / В.Н. Чикин //Путь и путевое хозяйство. - 1998. -№2.-С.12,13.

7. В. І. Жуков «Охорона праці на залізничному транспорті» -1999.-С.44.

8. Тюпкин, Ю.А. Обеспечение безопасности на железнодорожных переездах/ Ю.А. Тюпкин, О.В. Иванейкина // Железнодорожный транспорт РФ, СНГ за границей. ОИ ЦНТИ ТЄИ МПС. - 1996. -№23.-С.63.

9. Варбанец, Н. Г. Повышение безопасности движения в местах пересечения железнодорожного и автомобильного транспортных потоков [Текст]/ Н. Г. Варбанец // Інформ.-керуючі системи на залізн. трансп. - 2009. - № 3. - С. 30-32.

10. Позняков, В.А. Предупредить дтп на переездах/ В.А. Позняков //Путь и путевое хозяйство. - 1998. -№6. -С.32

Рецензент д-р техн. наук, професор О.М.Огар

Каліберда М.В. слухач групи МЗ-ОПУТ-13

Kaliberda Nikolay Viktorovich, student of the group M3-ROM-13 
УДК 656.21

\title{
ПІДВИЩЕННЯ ЯКОСТІ ОРГАНІЗАЦІЇ ТРАНЗИТНИХ ПЕРЕВЕЗЕНЬ ЗАЛІЗНИЦЯМИ УКРАЇНИ В СУЧАСНИХ УМОВАХ
}

Магістрант Д.І. Реутов

ПОВЫШЕНИЕ КАЧЕСТВА ОРГАНИЗАЦИИ ТРАНЗИТНЫХ ПЕРЕВОЗОК
ЖЕЛЕЗНЫМИ ДОРОГАМИ УКРАИНЫ ВСОВРЕМЕННЫХ УСЛОВИЯХ

Магистрант Д.И. Реутов

\section{THE QUALITY IMPROVEMENT ORGANIZATION TRANSIT RAILWAYS OF UKRAINE IN CURRENT CONDITIONS}

\author{
master student D.I. Reutov
}

Сприятливе географічне положення України, наявність розвинутої транспортної інфраструктури, а також показники експорту-імпорту країн сусідів дають змогу зробити висновок про спільну защікавленість у підвищенні якості організащії транзитних перевезень.

Ключові слова: транзитні перевезення, транспортна інфраструктура, міжнародні транспортні коридори, транзитні вантажопотоки.

Благоприятное географическое положение Украины, наличие развитой транспортной инфраструктуры, а также показатели экспорта-импорта стран соседей позволяют сделать вывод об общей заинтересованности в повышении качества организации транзитных перевозок.

Ключевые слова: транзитные перевозки, транспортная инфраструктура, международные транспортные коридоры, транзитные грузопотоки.

The favorable geographical position of Ukraine, a well-developed transport infrastructure, as well as indicators of export-import of neighbours suggest a General interest in improving the quality of the organization of transit.

Keywords: transit, transport infrastructure, international transport corridors, transit traffic.

Вступ і постановка проблеми у загальному вигляді та їі зв'язок із важливими науковими та практичними завданнями. Україна $є$ активним учасником глобальної та регіональної економічної діяльності. Вона має винятково вигідне географічне положення - якраз на шляху значних транзитних товаропотоків між Азією та Європою, Північчю та Півднем. Наявність розгалуженої транспортної мережі за умов активної зовнішньоекономічної діяльності, перетворює нашу державу у провідного транзитера на всьому євразійському просторі. Потенціал збільшення транспортних потоків та заходи щодо формування Єдиного Економічного Простору стимулюють Україну до реалізації свого потужного транзитного потенціалу. I це $є$ тим логічніше, що саме Україні за даними проведених досліджень [1] присвоєно коефіцієнт 3,11 - найвищий транзитний рейтинг серед усіх європейських країн.

Залізниці України $є$ не тільки вагомою частиною народно господарського комплексу країни,але також служать значним транзитним коридором між Сходом i Заходом. Сьогодні вони безпосередньо межують і взаємодіють із залізницями Росії, Білорусі, Молдови, Польщі,Румунії, Словаччини, Угорщини, забезпечують роботу 3 міжнародним 56 залізничним переходах, а також обслуговують 18 українських морських портів ЧорноморськоАзовського басейну, а також річок Дніпра та Дунаю.

Визначення мети та задачі дослідження. Позначити методи підвищення 
якості в організації транзитних перевезень по залізницям України, та підвищення ефективності перевезень, в сучасних.

Аналіз останніх

Питанням дослідження транспортних коридорів та транзитних перевезень в Україні присвячені значна кількість праць $[8,9,10,11]$, але в сучасних умовах інформаційних та автоматизованих систем виникає необхідність перегляду деяких підходів.

Основна частина дослідження. Глобалізація економіки і супроводжуючі ii процеси розвитку зовнішньоторговельного обміну вимагають нових підходів до розвитку транспорту, пошуку нових технологій і раціональних шляхів освоєння перевезень пасажирів i вантажів. Розширення міжнародного співробітництва та поглиблення інтеграційних процесів викликали необхідність створення міжнародної транспортної інфраструктури.

Для підвищення ефективності зовнішньо торговельних і транзитних зв'язків міжнародні організації зацікавлені європейські та азіатські країни приступили до формування системи міжнародних транспортних коридорів (МТК). В умовах розширення міжнародного співробітництва та поглиблення інтеграційних процесів, формування МТК належить провідна роль у вирішенні транспортних проблем,пов'язаних i3 забезпеченням міждержавних економічних, культурних та інших зв'язків, 3 доцільністю

створення

міжнародної

транспортної інфраструктури.

Проаналізуємо основні показники зовнішньоекономічних перевезень залізниць України, для можливості розробки ефективних та дієвих пропозицій щодо збільшення обсягів та підвищення якості транзитних перевезень на залізницях України.

Економіка України значною мірою орієнтована на зовнішню торгівлю. Це значить, що транспортно-економічні зв'язки за часів незалежності перетерпіли докорінні зміни. Їх основна частина перейшла в категорію міжнародних: експортних, імпортних i транзитних. Причому транзит перевищує експорт та імпорт більш ніж у два рази.

За рахунок експорту в Україні формується понад 50\% ВВП, тоді як 50\% ВВП припадає на імпорт. Таким чином, економіка України більш ніж на 100\% пов'язана із зовнішньоторговельним оборотом.

Основний

обсяг

зовнішньоекономічних вантажопотоків проходить у напрямку Схід-Захід. 3 країнами СНД Україна формує близько 50\% експортно-імпортних товаропотоків, на них припадає 90\% транзиту

У таблиці 1.1 наведено дані про динаміку транзитних вантажів кожним видом транспорту за 7 років.

Таблиця 1.1

Динаміка транзитних вантажопотоків за видами транспорту, тис. т

\begin{tabular}{|l|l|l|l|l|l|l|l|}
\hline & 2005 & 2006 & 2007 & 2008 & 2009 & 2010 & 2011 \\
\hline Усього & 205565,25 & 222948,1 & 386956,6 & 325423 & 178134,1 & 152353,8 & 151243,0 \\
\hline трубопровідним & 127921,9 & 143721,2 & 279802,4 & 223497,9 & 127981,7 & 99440,26 & 93119,52 \\
\hline залізничним & 73221,04 & 75050,72 & 99882,37 & 93347,6 & 44834,64 & 44511,77 & 48669,54 \\
\hline морським & 3765,54 & 2516,11 & 2693,97 & 3486,97 & 1899,38 & 3660,41 & 3912,07 \\
\hline автомобільним & 636,1 & 1614,14 & 4494,61 & 4908,71 & 3354,2 & 4649,12 & 5011,2 \\
\hline річковим & 10,11 & 18,5 & 37,43 & 74,73 & 0 & 0 & 0 \\
\hline авіаційним & 1,4 & 1,17 & 1,28 & 1,54 & 1,17 & 1,58 & 2,8 \\
\hline інше & 9,16 & 26,33 & 44,54 & 105,54 & 62,94 & 90,64 & 527,84 \\
\hline
\end{tabular}

3 таблиці 1.2, яка наочно зображує динаміку зміни вантажопотоки, зокрема залізничного транспорту України у транзитному сполученні протягом періоду з
2005 по 2011 роки, можна зробити висновок, що протягом останніх років спостерігалося поступовий спад обсягів міжнародного транзиту, виконаного залізничниками 
України з 2008 року пов'язується перш за все 3 економічною кризою, яка охопила світове виробництво товарів.

Транзитним потенціалом країни називають інтегральний показник потенціальних транзитних можливостей території країни з урахуванням пропускної спроможності іiї транспортно-транзитної інфраструктури. Він має декілька видів: наявний, перспективний та реально затребуваний. Останній кількісно характеризує конкурентоспроможність даної країни на світовому транспортному ринку [2]. Транзитний потенціал країни не є сталою величиною. Він змінюється залежно від динаміки кількісних та якісних характеристик потужностей об'єктів і засобів транзиту, а також від створених умов i встановлених правил функціонування сфери транспорту.

Визначальним фактором, що має безпосередній вплив на частку транзитного потенціалу України, яка реалізується залізничним транспортом, є технічний стан вітчизняної залізничної мережі. Починаючи з 1990 року залізниці України, незважаючи на економічні труднощі в державі, постійно модернізувалися та розвивалися.

Експлуатаційну характеристику залізничних шляхів сполучення наведено у таблиці 1.2 на основі [3].

Таблиця 1.2

Експлуатаційна характеристика залізниць України в динаміці протягом 1990-2010 років

\begin{tabular}{|l|c|c|c|}
\hline \multicolumn{1}{|c|}{ Показники } & \multicolumn{3}{|c|}{ Період } \\
\cline { 2 - 4 } & $\mathbf{1 9 9 0}$ & $\mathbf{2 0 0 0}$ & $\mathbf{2 0 1 0}$ \\
\hline $\begin{array}{l}\text { 1. Колії загального користування, в тому числі } \\
\text { електрифіковані, тис. км. }\end{array}$ & 8,1 & 9,1 & 9,1 \\
\hline Частка від загальної довжини, \% & 36 & 41 & 41 \\
\hline 2. Неелектрифіковані, тис. км & 14,7 & 13,2 & 12,1 \\
\hline Частка від загальної довжини, \% & 64 & 59 & 56 \\
\hline 3. Двоколійні, багатоколійні дільниці, тис. км & 7,6 & 7,3 & 7,2 \\
\hline Частка від загальної довжини, \% & 33 & 33 & 33 \\
\hline 4. Обладнані автоблокуванням, тис. км & 14,1 & 13,5 & 13,4 \\
\hline Частка від загальної довжини, \% & 62 & 60 & 59 \\
\hline
\end{tabular}

Значну роль при залученні транзитних вантажів відіграють експедиторські компанії: на їх долю припадає більше половини транзитного вантажопотоку, а на прикладі країн 3 розвиненою ринковою економікою видно, що саме експедиторська діяльність становить від 4 до $10 \%$ валового внутрішнього продукту.

На розвиток та реалізацію експортного потенціалу українського транспортного комплексу впливає велика кількість різноманітних факторів. Ступінь їх впливу неоднакова, проте, як показує практика виключити будь-який 3 них не можна.

3 метою підвищення ефективності зовнішньоторговельних і транзитних зв'язків міжнародні організації зацікавлені європейські та азіатські країни сформували систему міжнародних транспортних коридорів (МТК), і цей процес триває. В даний час МТК відіграють провідну роль у вирішенні транспортних проблем, пов'язаних iз забезпеченням міждержавних економічних, культурних та інших зв'язків.

У Європі 3 проектом створення транспортних коридорів виступила Єврокомісія ще в 1980-х роках. Його основною метою стала оптимізація транспортних потоків в Західній Європі. При цьому акцент був зроблений на розвиток транспортної інфраструктури країн Східної Європи для забезпечення зростання вантажопотоку між Європою і країнами Південно-Східної Азії. Використання для цих цілей портів Болгарії, Румунії та України дозволяє розвантажити від автотранспорту дороги Західної Європи. Ця політика відповідає і загальній стратегії $€$, спрямованої на підвищення екологічних стандартів і збільшення частки найбільш 
екологічних видів транспорту: залізничного і водного. У країнах ЄС 44\% від загального обсягу перевезень припадає на автомобільний транспорт, $41 \%$ - на морський, 8\% - на залізничний і 4\% - на внутрішній водний. В Україні в останні роки частка залізничного транспорту становить $50-55 \%$, морського - близько $25 \%$, автомобільного - 20-25\%.

Основні транспортні зв'язки між Україною та іншими державами здійснюються саме за напрямами міжнародних транспортних коридорів, тому ïx розвиток $\epsilon$ пріоритетним напрямком діяльності залізниць України, як основи інтеграції українського залізничного транспорту в європейську i світову транспортні системи.

По території України проходять 3-й, 5-й, 7-й і 9-й пан'європейських коридору:

№ 3 - Брюссель - Аахен - Кельн Дрезден - Вроцлав - Катовіце - Краків - Львів - Київ;

№ 5 - Венеція - Трієст/Копер Любляна - Марібор - Будапешт - Ужгород Львів - Київ, довжина 1 тис. км;

№ 7 - по Дунаю (водний), Австрія Угорщина - Югославія - Болгарія - Румунія Молдова - Україна, довжина 2,3 тис. км;

№ 9 - Гельсінкі - Виборг - СанктПетербург - Псков - Москва - Калінінград Київ - Любашівка/Роздольна (Україна) (з подальшою гілкою до Одеси) - Кишинів Бухарест - Димитровград - Александрополіс (3,4 тис. км).

Крім того, через Україну проходять шість коридорів Організації співробітництва залізниць (ОСЗ):

№3 - Польща - Україна - Росія, загальна протяжність 2209 км;

№4 - Чехія - Словаччина - Польща Угорщина - Україна, загальна протяжність 3 відгалуженнями 2711 км;

№5 - Угорщина - Словаччина Україна - Росія - Казахстан - Грузія Азербайджан - Молдова - Китай Киргизстан, довжина основної траси становить 11486 км; 1520 км;
№8 - Україна - Росія - Казахстан Узбекистан - Туркменістан, загальна протяжність 5115 км;

№10 - Грузія - Азербайджан Туркменістан - Узбекистан - Киргизстан Таджикистан - Казахстан (наземна частина), 3 використанням поромних переправ 3 Болгарії, Румунії і України в Грузинський морські порти, загальна протяжність коридору - 8847 км [4].

У 1996 р. Україна приєдналася до МTК Свропа - Кавказ - Азія (TRACECA), спільно 3 Польщею почалася реалізація проектів МТК Гданськ - Одеса, а також Європа - Азія (через прикордонні переходи у Донецькій i Луганській областях 3 направленням на Казахстан).

У перспективі передбачається створення нового транспортного коридору Азія-Свропа через Україну, Росію, Словаччину та Австрію 3 шириною колії 1520 мм. Для цього необхідно буде побудувати близько 500 км ж/д колії від словацького Кошице до Відня.

Загальна протяжність мережі залізничних транспортних коридорів на території України становить 3,2 тис. км і сьогодні за обсягами таких вантажних перевезень українські залізниці посідають четверте місце в Європі та шосте у світі (понад 60\% усіх транзитних вантажів).

В останні роки, поряд з ослабленням транзитного потенціалу України, продовжується розробка і реалізація великих міжнародних транспортних проектів, передбачають створення євроазіатських зв'язків в обхід території України на основі утворення нових коридорів, альтернативних українським. Крім того, значну конкуренцію у сфері залізничного транзиту Україна відчуває 3 боку сусідніх держав, зокрема, Республіки Білорусь.

Для залучення вантажів залізничні адміністрації України, Грузії, Казахстану та Азербайджану погодили наскрізні тарифи i ввели знижки на друге півріччя 2010 р. на перевезення універсальних контейнерів міжнародним транспортним коридором. Зокрема, «Укрзалізниця» ввела $20 \%$ знижку на перевезення великотоннажних 
універсальних контейнерів 3 країн $Є C$ в порти Іллічівськ, Керч, Одеса і у зворотному напрямку [7].

Значну увагу на залізних дорогах України приділяється розвитку інтермодальних перевезень, забезпечують можливість одночасного перевезення у складі поїзда універсальних і спеціалізованих контейнерів, а також автопоїздів.

Міжнародні транспортні коридори на території України мають велике державне значення. Ихдальнейшее розвиток являє собою досить складну проблему, що включає комплекс різних технічних, організаційних, економічних, юридичних та інших питань. Однією 3 головних цих проблем $\epsilon$ неузгодженість дій окремих елементів єдиної транспортної ланцюга, відсутність ефективної координації в роботі профільних органів державного управління та силових структур, недосконалі прикордонні та митні процедури, а також корупція на всіх рівнях організації транспортування вантажів. Непрозорість митних i прикордонних процедур при перетині кордону створюють значні бар'єри для торгівлі, що не дає можливості Україні повністю реалізувати свій потенціал транзитної країни. Та власники вантажів, та представники їх інтересів, у процесі перевезення експедитори, вказують на те, що в Україні доводиться оформляти велику кількість документів, передбачених регламентом роботи як «Укрзалізниці», так і контролюючих органів (митниці, санітарного та ветеринарного контролю, прикордонників та багатьох інших). Тому, якщо не будуть спрощені процедури контрольно- перевірочних операцій оформлення документів на транзитні вантажі, гармонізоване законодавство транспортників i митниці, вдосконалено правова база в частині забезпечення збереження вантажів при транспортуванні, впроваджено сучасні інформаційні системи, що спрощують документообіг, - поліпшити ситуацію 3 транзитними перевезеннями навряд чи вдасться [5].

$\begin{array}{lllr}\text { Висновки } & \text { дослідження } & \text { i } \\ \text { перспективи, подальший } & \text { розвиток } & \text { у } \\ \text { даному напрямку. Таким } & \text { чином, для }\end{array}$ даному напрямку. Таким чином, для до транс'європейської залізничної мережі необхідно: розробити заходи державної підтримки, спрямованої на регулювання міжнародної діяльності; гармонізувати нормативно-правову базу у сфері залізничного транспорту відповідно до міжнародно - правових норм; забезпечити техніко-технологічне зближення рухомого складу та транспортної мережі України 3 європейською транспортною системою; наблизити технічні, технологічні та екологічні стандарти 3 європейськими; привести у відповідність 3 європейськими стандартами шляхом модернізації та реконструкції основні маршрути, які можуть бути включені в загальноєвропейську транспортну систему; розвинути систему інформаційного забезпечення залізничної галузі на основі сучасних інформаційних технологій. Для вирішення всіх цих проблем потрібна координація дій всіх структур, що забезпечують формування та ефективне використання транспортних коридорів. I тут також необхідно посилення регулюючої ролі держави.

\section{Список використаних джерел}

1 Блудова Т. Глобалізація транспортної системи та поняття „транзитний потенціал країни” // Економіка України. - 2006. - № 10. - С. 21-26.

2 Леонтьев Р.Г., Хмель В.А. Альтернативные стратегии развития транзитного потенциала Российской Федерации. // Транспорт: наука, техника, управление. - 2006. - №10. - c. $8-10$.

3 Довідник основних показників роботи залізниць України $(1997$ - 2007 р.) - К.: Укрзалізниця, 2003. - 39с.

4 Глонти А. Международные транспортные коридоры Организации сотрудничества железных дорог / А. Глонти // Бюллетень ОСЖД. - 2009. - № 4-5. - С. 32- 34. 
5 Украина - лидер по мощности транзитного потенциала и аутсайдер по эффективности его использования [Электроний ресурс]. - Режим доступу: http://uzinfo.net/ru/press/13897.

6 Проблемы и перспективы международных транзитных перевозок [Электроний pecypc]. - Режим доступу: http://econindustry.org/arhiv/html/2011/st_56_04.pdf

7 Експортний та траний потенціал України [Электроний ресурс]. - Режим доступу: http://mail.geekrunner.org/83/111/

8 Панченко, С.В. Інтермодальні перевезення як ключовий чинник підвищення ефективності роботи транспорту в умовах формування міжнародних транспортних коридорів України [Текст] / С.В. Панченко // Вісник економіки транспорту і промисловості № 42, 2013 С. 7-8

9 Підлісний, П.І. Передумови організації мультимодальних перевезень вантажів вітчизняними операторами на міжнародному ринку транспортних послуг [Текст] / Підлісний П.І., Брайковська А.М // Економіст, № 10 (300), 2011 р. С.25-30.

10 Трансальпийские перевозки компании Railion - состояние, опыт, перспективы / ЖД мира,- №12, - 2006 [Электронный ресурс] // Режим доступа: www/URL:http:/www.zdmira.com/ 31. Украина остается одной из рисковых стран региона для интермодальных операторов, Транспорт і логістика, 10.11.2011

11 Козак В.В. Розробка моделі розвитку інтероперабельності міжнародних залізничних транспортних коридорів на стратегічному рівні планування перевезень / В.В. Козак, Т.В. Бутько, А.В. Прохорченко // Інформаційно-керуючі системи на залізничному транспорті. - 2011.- № 3. - С. 36-41.

Рецензент д-р техн. наук, професор О.М.Огар

Реутов Дмитро Ігорович слухач групи МЗ-ОПУТ-13

Dmytro Igorovych Reutov, student of the group M3-ROM-13

УДК 656.073.41:658.286.4

\title{
ІНТЕРОПЕРАБЕЛЬНІСТЬ ЯК НЕОБХІДНА СКЛАДОВА ФУНКЦІОНУВАННЯ ЗАЛІЗНИЦІ ТА ЇЇ ПІДРОЗДІЛІВ
}

К-т техн. наук Т.Ю. Калашнікова, магістрант С.О. Масалов

\section{ИНТЕРОПЕРАБЕЛЬНОСТЬ КАК НЕОБХОДИМАЯ СОСТАВЛЯЮЩАЯ ФУНКЦИОНИРОВАНИЯ ЖЕЛЕЗНОЙ ДОРОГИ И ЕЁ ПОДРАЗДЕЛЕНИЙ}

\author{
К-т техн. наук Т.Ю. Калашникова, магистрант С.А. Масалов
}

\section{INTEROPERABILITY AS THE NECESSARY CONSTITUENT PART OF RAILWAY AND ITS SUBDIVISIONS FUNCTIONING}

Cand. of techn. sciences T.Y. Kalashnikova, master student S.A. Masalov

В статті визначене поняття інтероперабельності у застосуванні до залізничного транспорту, неведені ї̈ основні принщипи. Також досліджуються питання застосування принщипів інтероперабельності у міжнародному сполученні та при удосконаленні організації вантажних перевезень на залізничях України у тому числі на під’їзих коліях.

Ключові слова: інтероперабельність залізниць, міжнародне сполучення, промисловий транспорт, інформачійно-керуюча система.

B cтатье определено понятие интероперабельности в приминении $к$ железнодорожному транспорту, приведены ее основные принщипы. Также исследуются 
вопросы применения принщипов интероперабельности в международном сообщении и при усовершенствовании организации грузовых перевозок на железных дорогах Украины в том числе и на подъездных путях.

Ключевые слова: интероперабельность железных дорог, международное сообщение, промышленный транспорт, информационно-управляющая система.

The notion "interoperability" applying to railway transport is determined in the article as well as its main principles are given. Problems connected with the application of interoperability principles to international communication and while improving freight traffic organization on railways of Ukraine and local railways are also investigated.

Keywords: railway interoperability, international traffic, industrial transport, information control system.

\section{Вступ i постановка проблеми.} Сучасний стан міжнародних економічних відносин характеризується потужним розвитком процесу глобалізації, що обумовлює активізацію зовнішньоекономічних зв'язків між країнами світу та вимагає належного рівня розвитку національних транспортних систем, які виступають елементами інфраструктури світового господарства та забезпечують реалізацію цих зв'язків. 3 огляду на це досить актуальним постає питання дослідження особливостей розвитку світової транспортної системи та національних транспортних систем країн світу, зокрема особливої уваги гідні питання інтероперабельності залізниць.

\begin{tabular}{cllr}
\multicolumn{1}{c}{ Мета } & i задачі & дослідження. В \\
сучасних & умовах & роль
\end{tabular}
інтероперабельної роботи залізниць помітно зростає, як 3 огляду i на економічну орієнтованість роботи транспорту, так і впливу на основні показники роботи залізничних підрозділів в цілому. Тому виникає необхідність більш детального розгляду цього поняття, виявлення основних проблем на шляху до досягнення задовільного рівня інтероперабельності перевізного процесу та можливих варіантів вирішення цих питань.

Виклад основного матеріалу. Згідно визначенню, даному в стандарті ISO/IEC 24765, Systems and Software Engineering Vocabulary Інтероперабельність - це здатність двох чи більше систем або елементів обмінюватися інформацією та використовувати цю інформацію. Однак термін «інтероперабельність» визначає не простий обмін інформацією та використання iï, але й забезпечення узгодженої взаємодії учасників, для чого повинно бути досягнуто загальне поняття цілей і методів взаємодії [1].

Інтероперабельність, як явище можна умовно поділити на два види:

- технічна - здатність систем та їх компонентів до взаємодії між собою;

- організаційна - спроможність суб'єктів, об'єктів та процесів до узгодженого функціонування.

Інтероперабельність у застосуванні до залізничного транспорту передбачає здатність двох чи більше систем залізниць забезпечувати безпечний та безперервний рух поїздів, що відповідає експлуатаційним вимогам цих ліній. Ця іiі здатність має грунтуватися на сукупності регламентних, технічних та експлуатаційних умов, що мають бути виконані з метою задоволення основоположних вимог. Тобто принцип інтероперабельності полягає у створенні умов щодо повної сумісності параметрів функціонування транспортної мережі (ширина залізничної колії, габарит) та характеристик транспортних засобів, що створює умови щодо посилення взаємодії транспортних систем різних країн. Таким чином, упровадження інтероперабельності на залізничному транспорті насамперед передбачає створення нових стандартів, спрямованих на забезпечення роботи 3 гармонізації технічних вимог та адаптації залізничного транспорту для його інтеграції в суміжні транспортні системи.

Необхідність зробити залізничний транспорт більш сумісним, аби він був конкурентоспроможним, та збільшити його частку на ринку постійно зростає: концепція 
взаємодії сьогодні перебуває в центрі будьякого плану або проекту 3 розвитку залізничної системи.

До основних цілей залізничної інтероперабельності можна віднести:

- усунення технічних бар'єрів у взаємній торгівлі;

- підвищення рівня безпеки

залізничної продукції;

- зменшення втрат (фінансових i часових) на підтвердження безпеки цієї продукції;

- посилення

відповідальності

виробників і постачальників щодо безпеки продукції.

Також

розглядають

інтероперабельність залізниць на трьох рівнях[2]:

1) корпоративний рівень - співпраця між транспортними компаніями,

визначення загальної структури керівництва на різних рівнях;

2) юридичний рівень - гармонізація транспортної документації та

міжнародного законодавства;

3) культурно-побутовий рівень зниження культурних та побутових

бар'єрів при наданні транспортних послуг.

Більш детально значення інтероперабельності можна розглянути на прикладі взаємодії систем колії 1520 мм і 1435 мм на кордоні Україна-СС. Зокрема, по даним прес-служби Укрзалізниці загальний річний обсяг імпортних перевезень становить 36,2 млн тонн, експортних - 141,3 млн тонн, транзитних - 29,5 млн тонн, що взагалі у зовнішньому сполученні складає 207 млн тонн вантажів та 53,13 \% від загального вантажообігу залізниць України, що підкреслює велику питому вагу міжнародного залізничного сполучення [3]. Беручи до уваги наявність економічних передумов та те, що по даним прес-службі Міністерства інфраструктури України потенціал західних переходів, за оцінками фахівців, також експлуатується на рівні 70\% від запланованої потужності виникає можливість збільшити вантажообіг 3 країнами 6 .
Задля підвищення транспортної та торгівельної кооперації 3 боку Європейського Союзу було прийнято ряд нормативних документів направлених на підвищення рівню інтероперабельності залізничного транспорту:

$$
\text { - директива 96/48/СС Про }
$$

експлуатаційну

транс'європейських

сумісність

систем;

- директива 2001/16/СС Про експлуатаційну сумісність звичайних залізничних ліній;

- директива 2004/50/СС, що вносить зміни у дві попередні директиви. Зазначені документи спрямовані на зменшення розбіжностей у системах, покращення безпеки руху поїздів, коли вони ізс воєї національної мережі входять у міжнародну мережу. Повне відкриття залізничної мережі міжнародних вантажних перевезень означає необхідність введення інтероперабельності в межах усієї міжнародної залізничної галузі [4].

Процес інтероперабельності залізниць включає декілька пунктів:

- установлення єдиних правових рамок щодо процедур перевірки дотримання основних вимог із питань безпеки, здоров'я, технічної сумісності, надійності, доступності та впливу на навколишне середовище;

- застосування єдиної процедури для експлуатації поїздів по одній інфраструктурі;

- пошук необхідного рівня технічної сумісності, достатньої для експлуатації та руху різних типів рухомого складу;

- пошук рівня технічної узгодженості для поступового переходу внутрішнього ринку на обладнання, послуги й конструкції для оновлення, модернізації та безпечної експлуатації залізничної мережі.

Також для підвищення інтероперабельності основними заходами, згідно 3 Транспортною стратегією України та програмою ЄС для України «Підтримка інтеграції України до Транс'європейської транспортної мережі ТЄМ-Т», є комплексна оптимізація роботи залізниць України, що спрямована на підвищення ефективності якості експлуатаційної роботи та сприяння зростанню обсягів використання 
мультимодального, інтермодального

та комбінованого транспорту в Україні [5].

Система комбінованих перевезень складається із трьох основних частин. Це контейнерні та контрейлерні перевезення, а також перевезення рухомим складом на автомобільно- залізничному ході, тобто бімодальним транспортом. При комбінованих перевезеннях вантажною одиницею вважаються контейнери, змінні кузови, напівпричепи та автопоїзди [6].

\section{Окрім}

комбінованих

$$
\text { розвитку }
$$$$
\text { перевезень, }
$$

системи

Укрзалізницею постають також удосконалення морально та фізично застарілих інфраструктурних складових (пристрої СЦБ, рухомий склад та ін.), організаційної роботи та перегляду підходів до роботи на ринку транспортних послуг України.

Особливим $є$ питання розширення використання принципів логістики та сучасних транспортних технологій $\mathrm{y}$ вантажній роботі залізниць, що у найближчій перспективі дає можливість покращення показників роботи залізничного транспорту та підвищення його конкурентоспроможності.

На сьогоднішній день близько $80 \%$ вантажної роботи залізниць виконується на місцях незагального користування. В сучасних умовах взаємодія між залізничним транспортом та підприємствами-клієнтами потребує перегляду як у сфері правовідносин, так i у інформаційній та технологічній сферах.

Особливим $є$ питання інформаційної інтероперабельності залізниці із підприємствами клієнтами на рівні використання діючих та перспективних інформаційно-керуючих систем (IКC).

Однією iз причин зниження показників роботи залізниці $\epsilon$ неефективне використання рухомого складу. За даними Укрзалізниці 39,5\% ефективного рухомого складу знаходиться під простоєм на

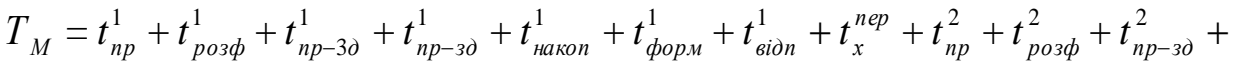

$$
\begin{aligned}
& +t_{n p-3 \partial}^{2}+t_{\text {накоп }}^{2}+t_{\text {форм }}^{2}+t_{\text {вidn }}^{2}
\end{aligned}
$$

під’їзних коліях (рис. 1), що суттєво впливає на показники роботи залізниці. Вирішенням цієї проблеми $є$ удосконалення технології роботи промислового підприємства залізничного транспорту (ППЗТ) та його IКС. Але для більш ефективного результату необхідно виконання умови інтероперабельної роботи діючої ІКС магістрального залізничного транспорту 3 ІКС ППЗТ.

Велика кількість ППЗТ України мають розгалужену мережу колійного розвитку і примикають до магістрального залізничного транспорту через декілька станцій примикання магістрально залізничного транспорту. На основі розроблених Єдиних технологічних процесів роботи під'їзної колії та станції примикання для кожного 3 підприємств-контрагентів ППЗТ визначено, з якої станції примикання буде виконуватися подавання та забирання вагонів. Облік часу користування вагонами та нарахування плати за користування здійснюється лише на відповідних станціях. Це обумовлено Правилами перевезення вантажів. Але існує варіантна технологія взаємодії магістрального залізничного транспорту та ППЗТ, яка вимагає перегляду тарифної політики УЗ та договірних правовідносин із клієнтами. Полягає ця технологія у можливості розподілення вагонів під навантаження в межах ППЗТ [8].

Наявна модель обігу вагона при взаємодії ППЗТ відображена на рис. 2.

Відповідно до існуючої технології роботи час обороту вагону при взаємодії станцій примикання і під’їзих колій складе:

$$
T=T_{M}+T_{\Pi P}+T_{O Б P}^{Д C},
$$

де $T_{M}$ - час знаходження вагону на магістральному транспорті, год;

$T_{\Pi Р}$ - час знаходження вагону на промисловому транспорті, год;

$$
T_{\text {ОБР }}^{\text {ДС }} \text { - час на обробку поїздів на }
$$

дільничній станції, год; 
де $t_{n p}^{1}, t_{n p}^{2}-$ норми часу на операції по прийманню поїздів відповідно на першій і на другій станціях примикання, год;

$t_{\text {розф}}^{1}, t_{\text {розф }}^{2} \quad-\quad$ норми часу на розформування поїздів відповідно на першій і другій станціях примикання, год;

$$
t_{n p-3 д}^{1}, t_{n p-3 д}^{2}-\text { норми часу на прийомо- }
$$

здавальні операції при передачі вагонів зі станцій примикання на під'їзні колії (одна хвилина на вагон, але не більше 30 хвилин на групу вагонів), год; $t_{\text {нако }}^{1}, t_{\text {нако }}^{2}-$ час на накопичення вагонів на состав при їх відправленні за станцій, год; $t_{\phi o p м}^{1}, t_{\phi о р м}^{2}-$ норми часу на формування составів, год;

$t_{\text {вidn }}^{1}, t_{\text {sidn }}^{2}$ - норми часу на операції по відправленню на станціях примикання, год.

$t_{x}^{\text {nep }}$ - час ходу поїзда по перегону 3 першої станції примикання до другої станції примикання, хв.

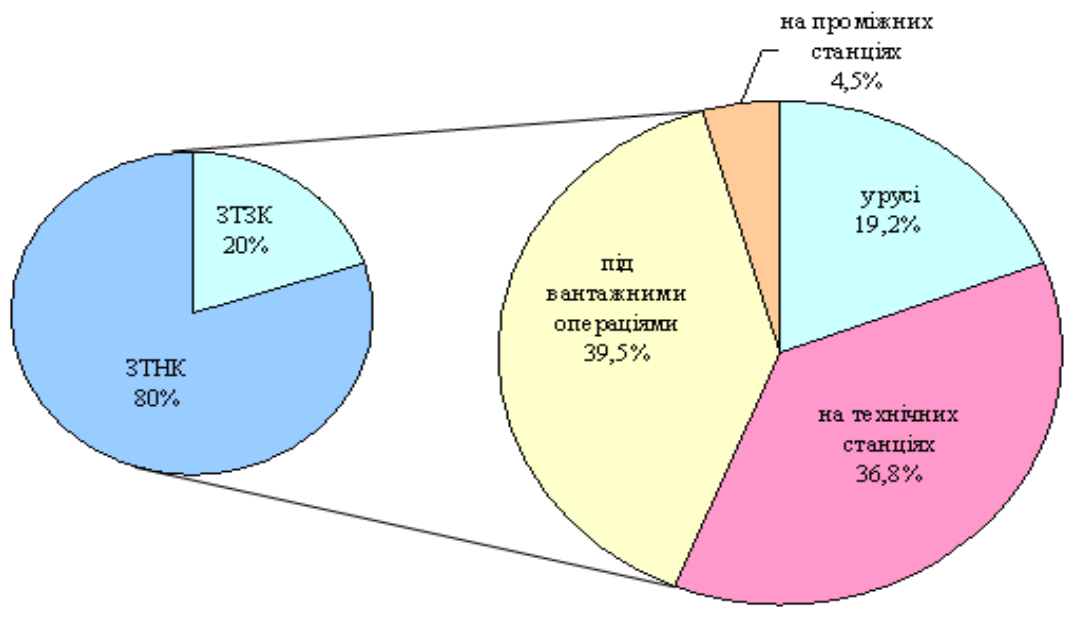

Рисунок 1 - Діаграма порівняння часу знаходження вагону при його обороті

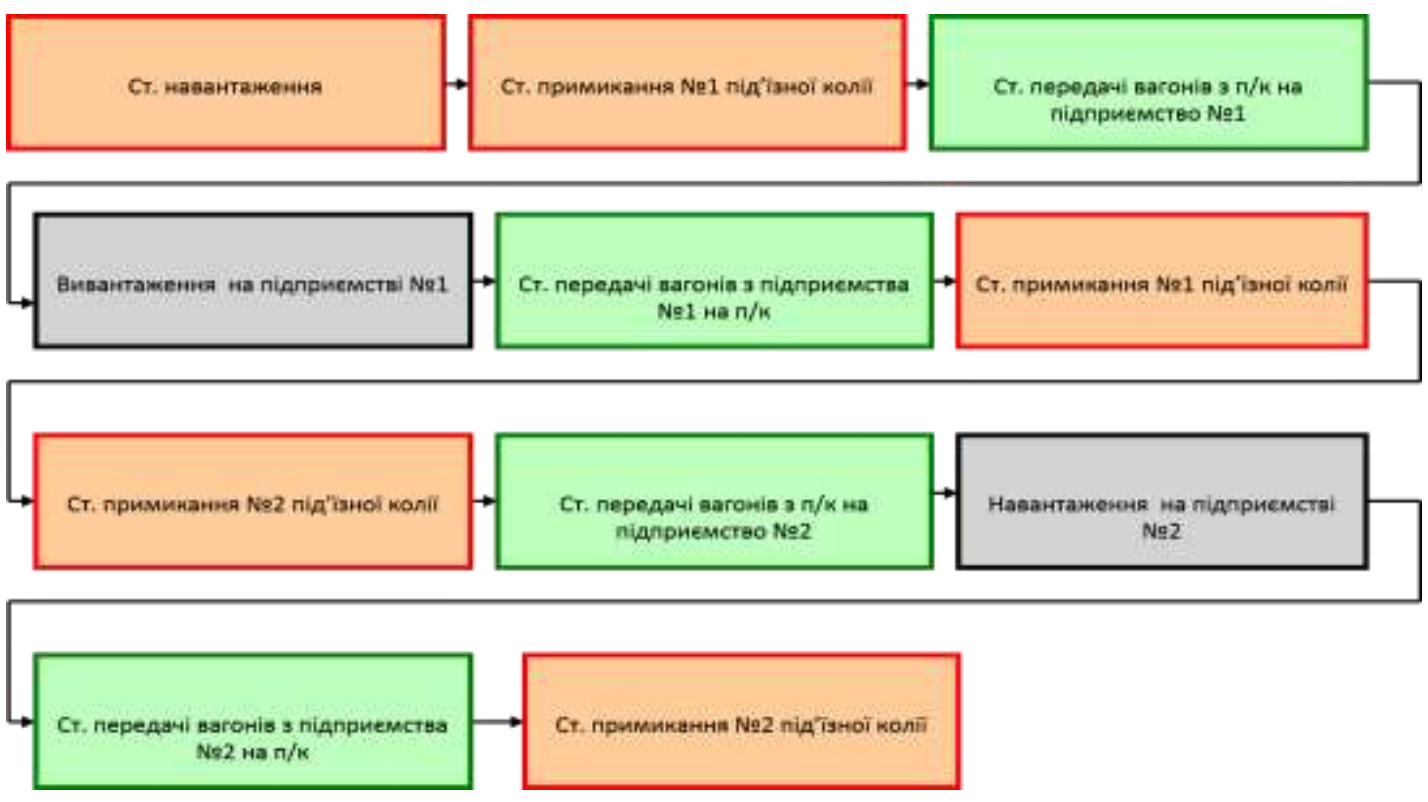

Рисунок 2 - Схема обігу вагона при існуючій технології роботи станцій примикання та під’їзної колії ППЗТ

$T_{\text {IIP }}=t_{\text {nод }}^{1}+t_{\text {вив }}+t_{\text {nриб }}^{1}+t_{\text {nод }}^{2}+t_{\text {нав }}+t_{\text {nриб }}^{2}$,

(3) де $t_{\text {nод }}^{1}, t_{\text {nод }}^{2}$ - час на подавання вагонів 3 передавальних колій станцій примикання на вантажні фронти підприємств, год; 


$$
t_{y \sigma}^{1}, t_{y \sigma}^{2}-\text { час на прибирання вагонів } 3
$$
вантажних фронтів підприємств на передавальні колії станцій примикання, год;

$t_{\text {вив }}-$ час на вивантаження групи вагонів, год;

$t_{\text {нав }}-$ час на навантаження групи вагонів, год.

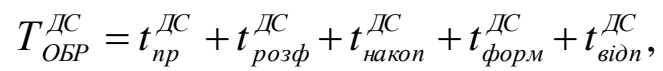

$$
\begin{aligned}
& T_{M}=t_{n p}^{1}+t_{\text {розф }}^{1}+t_{n p-з д}^{1}+t_{n p-3 д}^{2}+t_{\text {нако }}^{2}+t_{\text {фор }}^{2}+t_{\text {від }}^{2},
\end{aligned}
$$

Час знаходження вагонів на мережі промислового залізничного транспорту:

$$
T_{\text {ПІР }}=\left(t_{\text {nод }}^{1}+t_{\text {вив }}+t_{\text {nриб }}^{1}\right) \cdot n_{\beta}^{1}+t_{X}^{\Pi I I T T}++\left(t_{\text {под }}^{2}+t_{\text {нав }}+t_{\text {nриб }}^{2}\right) \cdot n_{\beta}^{2},
$$

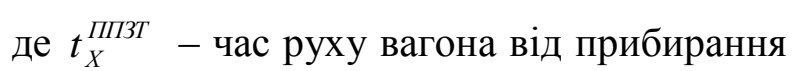
порожніх вагонів 3 фронтів вивантаження одного підприємства на фронти навантаження іншого підприємства всередині ППЗТ, хв.

Ефективність

варіантної технології перевіряється рішенням транспортної задачі.

Запропонована технологія дозволяє зменшити час обігу вагону, за рахунок зменшення порожнього пробігу, зменшити навантаження на основні засоби технічних станцій, через відсутність переробки порожнього вагонопотоку, зменшити час зайняття колій станцій та перегонів. Для визначення найбільш оптимального варіанту розподілу порожніх вагонів всередині ППЗТ доцільно створити систему підтримки прийняття рішень на автоматизованих робочих місцях оперативного персоналу, зокрема, удосконалення та впровадження інтероперабельних ІКС.

Висновки 3 дослідження i перспективи, подальший розвиток у даному напрямку. Таким чином, для більш ефективної роботи залізниці вцілому необхідно формування технологій взаємодії іï підрозділів 3 виконанням умови інтероперабельної роботи діючої IКC магістрального залізничного транспорту 3 IКС ППЗТ та розробка відповідних моделей 3 подальшою їх реалізацією. Також для ефективного застосування принципів інтероперабельності при удосконаленні організації перевезень в міжнародному сполученні виникає необхідність перегляду правовідносин, тарифної політики та сприяння розвитку мультимодального, інтермодального та комбінованого транспорту в Україні.

\section{Список використаних джерел}

1. Бородакий Ю. В. К проблеме обеспечения интероперабельности / Ю.В. Бородакий, Ю. Г. Лободинский // Информационные технологии и вычислительные системы. — 2009. № 5. - С. $16-24$.

2. Гармонізація як важливий аспект упровадження інтероперабельності на залізничному транспорті [Електронний ресурс] / О. Ткаченко, Д. Гнатенко, Т. Шелейко, А. Донченко // Українські залізниці . - 2014. - № 10. - С. 38-42. - Режим доступу: http://nbuv.gov.ua/j-pdf/ukrzal_2014_10_13.pdf

3. Укрзалізниця. Прес-центр [Електрон. ресурс]. - Режим доступу: http://uz.gov.ua/press_center/.

4. Определение перспективных направлений в области повышения эффективности контейнерной транспортной системы [Електронний ресурс] / В. С. Наумов, Т. А. Омельченко // Збірник наукових праць Дніпропетровського національного університету залізничного 
транспорту імені академіка В. Лазаряна. Транспортні системи та технології перевезень . 2013. - Вип. 6. - С. 72-75. - Режим доступу: http://nbuv.gov.ua/j-pdf/znpdnu_tstp_2013_6_15.pdf

5. Юридична складова інтероперабельності залізничного транспорту України в контексті взаємин із країнами Європейського Союзу [Електронний ресурс] / О. Тітов // Українські залізниці . - 2014. - № 12. - С. 18-19. - Режим доступу: http://nbuv.gov.ua/jpdf/ukrzal_2014_12_5.pdf

6. Програма Європейського Союзу для України «Підтримка інтеграції України до Транс'європейської транспортної мережі ТЄМ-Т», РК7. Мультимодальний транспорт. Заключний звіт 7.1 [Електронний ресурс] // Режим доступу: www/URL: http://tent.org.ua/data/upload/publication/main/ua/517/fr_7.1_multimodal_uk.pdf.

7. Управління вантажною і комерційною роботою на залізничному транспорті [Текст] : підручник / А. М. Котенко. - Х. : ПП вид-во "Нове слово", 2003 . Ч. 1. - [Б. м.] : [б.в.], 2003. 407 с.: рис., табл. - Бібліогр.: с. 404-407.

8. Чеклов В.Ф. Аналіз системи взаємодії залізничних станцій з під’їзними коліями вугільних підприємств / В.Ф. Чеклов, Г.В. Бобик, А.М. Масалов, Є.Є. Шкуро // Збірник наукових праць ДонІЗТ. - 2006. - № 8. - С. 84 - 89.

9. Чеклов В.Ф. Створення комплексу моделей з обслуговування великих промислових районів за участю підприємства промислового залізничного транспорту на основі ресурсозбереження / В.Ф. Чеклов, О.О. Аніщенко, А.М. Масалов // Залізничний транспорт України. - 2009. - № 2. - С. $54-59$.

10. Чеклов В. Ф. Розробка комплексу планетарних моделей інтероперабельності промислового та магістрального залізничного транспорту / В. Ф. Чеклов, В. М. Чеклова, С. О. Масалов // Збірник наукових праць ДонІЗТ. - 2012. - № 30. - С. 28 - 33.

Рецензент д-р техн. наук, професор Є.С.Альошинський

Масалов Семен Олександрович, магістр ІППК Тел.(099) 900-70-13 e-mail: masalovs.s@yandex.ru

Калашнікова Тетяна Юрївна, к.т.н., дочент кафедри управління експлуатаџійної роботи Української державної академії залізничного транспорту Tел. (066)441-50-42 e-mail: bulavina_ty@ukr.net

Masalov Semen Oleksandrovich, Listener IPPK Tel. (099) 900-70-13 e-mail: masalovs.s@yandex.ru

Kalashnikova Tetyana Yurievna, PhD. Of tehn. Sciences, Associate Professor of Management of operational work of the Ukrainian State Academy of Railway Transport Tel. (066)441-50-42 e-mail: bulavina_ty@ukr.net

УДК 656.223
ПІДВИЩЕННЯ ЕФЕКТИВНОСТІ РОБОТИ ЗАЛІЗНИЧНО- ПЕРЕВАНТАЖУВАЛЬНОГО ВУЗЛА В УМОВАХ ЗАСТОСУВАННЯ ІНФОРМАЦЙНИХ ЛОГІСТИЧНИХ ТЕХНОЛОГІЙ

Д-р техн. наук Ломотько Д.В., магістранти Волосюк П.Ф., Емець І.Л.

ПОВЫШЕНИЕ ЭФФЕКТИВНОСТИ РАБОТЫ ЖЕЛЕЗНОДОРОЖНОГО ПЕРЕГРУЗОЧНОГО УЗЛА В УСЛОВИЯХ ПРИМЕНЕНИЯ ИНФОРМАЦИОННЫХ ЛОГИСТИЧЕСКИХ ТЕХНОЛОГИЙ

Д-р техн. наук Ломотько Д.В., магистранты Волосюк П.Ф., Емец И.Л.

\section{IMPROVING THE EFFICIENCY OF RAIL TRANSSHIPMENT HUB IN APPLICATION OF INFORMATION TECHNOLOGY LOGISTICS}

Doct. of techn. Sciences Lomotko D.V., masters student Volosyuk P.F., Yemets I.L.

Запропоновано підвищити ефективність роботи перевантажувального залізничного вузла за рахунок впровадження комплексної інформаційно-керуючої системи станції, філії 
та головного иентру транспортного сервісу. В умовах перевантажувальних залізничних вузлів В та Е встановлено термін окупності інформаційної системи на рівні 5.1 роки. 3 урахуванням економічних розрахунків показано можливість впровадити логістичні технології взаємодї видів транспорту у вузлі.

Ключові слова: залізниия, транспортний сервіс, логістика, інформаційна система

Предложено повысить эффективность работы перегрузочного железнодорожного узла за счет внедрения комплексной информационно-управляющей системы станции, филиала и главного центра транспортного сервиса. $B$ условиях перегрузочных железнодорожных узлов В и Е установлен срок окупаемости информационной системы на уровне 5.1 года. На основе экономических расчетов показана возможность внедрить логистические технологии взаимодействия видов транспорта в узле.

Ключевые слова: железная дорога, транспортный сервис, логистика, информационная система

Proposed to improve the efficiency of handling railway hub through the introduction of an integrated information management system station and a branch of the main center of the transport service. Currently, the territory of Ukraine organized and runs 14 container trains. Transportation of containers in container trains consisting of $40 \%$ of the total volume of containers transported through Ukraine. Given the possibility of using the potential of the transport market, is one of the promising direction of work to attract additional cargo flows to Ukraine and geographical expansion of international projects involving railways of Ukraine. This work deals with different areas of the Railways flexible tariff policy, new information technology, technical upgrading, improvement of border crossings and transportation process technology in general, and more.

In terms of transfer of railway junctions $B$ and $E$ set payback information system at the level of 5.1 years. On the basis of economic calculations the possibility to implement logistics technology interaction modes of transport in the node.

Keywords: railway transport services, logistics, information system

\section{Вступ}

Діяльність залізничних вузлів зі значними обсягами перевантаження технологічно пов'язано 3 роботою залізничного транспорту, однак інформаційна взаємодія в цьому процесі, як правило, знаходиться на невисокому рівні. Технологічний процес тісно зв'язаний із плануванням спільної діяльності усіх видів транспорту та вантажовласників, що при обробці великого вантажопотоку стає істотно необхідним. 3 іншого боку, планування перевезень пов'язано 3 розробкою оптимальної тарифної політики: в умовах наявності попередньої інформації про кількість прибуваючих вантажів стає можливим створювати оптимальні ставки на перевезення i переробку того чи іншого вантажопотоку. Усе це зв'язано 3 організацією безперервного перевізного процесу, технологічно та інформаційне забезпечення якого повинно базуватись на логістичних принципах.

\section{Постановка завдання}

Враховуючи становище, що склалось в галузі, можливо сказати, що більшість вантажів у контейнерах передаються 3 морського або автомобільного на залізничний транспорт, частка «прямого» варіанта перевантаження досягає 50\%. Регулювання цього вантажопотоку $\epsilon$ важливим ринковим інструментом підвищення конкурентоспроможності залізничної галузі.

За даними Укрзалізниці обсяги перевезень контейнерів за 11 місяців 2014 року зросли на $6,8 \%$ у порівнянні із 2013 роком. За січень-листопад 2014 року залізниці України перевезли в складі контейнерних та комбінованих поїздів у всіх видах сполучень (імпорт, експорт, транзит та внутрішні перевезення) 79,6 тис. контейнерів (в ДФЕ - 20-футовому еквіваленті), що на 6,78\% більше ніж у 2013 році, коли було перевезено 74,5 тис. контейнерів в TEU. 3 
них в комбінованих поїздах «Вікінг» перевезено 3675 контейнерів.

Найбільше перевезено за маршрутом Нікополь - Іллічівськ - Нікополь - 20064 контейнерів (у 2,4 рази більше ніж за аналогічний період минулого року), 12036 контейнерів - поїздом, що курсує за маршрутом Словаччина (Кошице) - Росія (Перспектива), 9704 - поїздом Румунія Росія (Москва) - Румунія (175,6\%).

Окрім того, маршрутами Румунія Тольятті - Румунія перевезено 10012 контейнерів - на 233,7\% більше, ніж за аналогічний період минулого року, «Ленд Брідж» (Китай - Угорщина) - 5868 од. (121,5\% до минулорічного), «Дніпровець» (Одеса - Дніпропетровськ -Ліски) - 3846 од., «Хрещатик» (Одеса --- Київ-Ліски) - 4565 контейнери, Польща - Україна (Ізов Могилів-Подільський) - Молдова (Рибниця) - 2724, ZUBR - 1588, «Поділля» (ОдесаХмельницький) - 2030 контейнерів в умовних од.

Наразі територією України організовано та курсує 14 контейнерних поїздів. Перевезення контейнерів у складі контейнерних поїздів становлять $40 \%$ від загального обсягу перевезених контейнерів територією України.

Враховуючи

можливість

використання потенціалу ринку

транспортних послуг, одним 3 перспективних $\epsilon$ напрямок проведення роботи щодо залучення додаткових вантажопотоків на територію України та розширення географії міжнародних проектів за участю залізниць України [3].

Ця робота стосується різних напрямків діяльності залізниць: гнучкої тарифної політики, впровадження нових інформаційних технологій, технічного переозброєння, удосконалення прикордонних переходів та технології перевізного процесу в цілому, тощо.

Це можливо зробити на основі зменшення невизначеності на транспортному ринку в районі тяжіння транспортних вузлів за рахунок прогнозування найбільш важливих показників обсягів перевезень у межах відповідних інформаційно-керуючих систем.

\section{Аналіз публікацій}

Відповідно до Закону [1] технологія роботи залізничного транспорту України повинна повністю забезпечити інтереси вітчизняної економіки та вантажовласників, у тому числі - за рахунок покращення транспортного обслуговування у транспортних вузлах при безумовному виконанні принципів раціонального використання вагонів i контейнерів, скорочення термінів доставки та підвищення збереження вантажів.

Передумовами формування i діяльності перевантажувальних вузлів в сучасних умовах невизначеності полягає в прогнозуванні рівня виробництва продукції в промисловості, сільському господарстві, будівництві, потреба в тї переміщенні на магістральному транспорті [2]. Цю технологію запропоновано реалізувати через формування системи транспортного сервісу. Зокрема державне підприємство «Український державний центр транспортного сервісу «Ліски», створене у 1995 p. наказом Мінтрансу України від 11.05.1995 р., № 189/1 та підпорядковується Укрзалізниці [4]. Термінали «Ліски» утворюють повноцінну мережу логістичних центрів у містах: Київ, Харків, Одеса, Дніпропетровськ, Донецьк, Луганськ i перевантажувальний комплекс у Чопі. Підприємство має необхідну інфраструктуру, сучасне технічне оснащення: складські приміщення, електрокозлові крани, навантажувально-розвантажувальні механізми, а також парк рухомого складу i транспортних одиниць: фітингові платформи, спеціалізовані платформи для контрейлерних перевезень, вагони автомобілевози для перевезення легкових автомобілів, великотон-нажні контейнери та сідельні тягачі.

За роки існування Центру, відповідно до вимог сучасного транспортного ринку, спектр його послуг значно розширився: організація перевезень вантажів (у тому числі у складі контейнерних поїздів і поїздів комбінованого транспорту), експедирування вантажів усіма видами транспорту, надання в користування контейнерів, усі види 
термінальних послуг, перевезення вантажів автотранспортом, доставка за схемою «від дверей до дверей»), організація послуг митного контролю та оформлення вантажів, послуги транспортної та складської логістики 3 використанням власних виробничих потужностей i транспортних засобів, зберігання вантажів (у тому числі в контейнерах) у режимі митно-ліцензійного складу і складу тимчасового зберігання.

Перевантажувальні вузли, як складні системи, мають певні властивості, i, насамперед, це синергічність, цілісність, централізованість, адаптивність, велика кількість зворотних, а також зовнішніх зв'язків [5, 8]. Ці факти мають істотний вплив на характер i процес формалізації технологічних процесів. Розвиток сучасних підходів у математиці та використання іiі методів в інших галузях знань складають одну з основних характерних рис сучасності [6].

Для центрів транспортного сервісу (ЦТС) актуальним стає питання проблема ресурсозбереження. Велику цінність має запропонований комплекс моделей [6] технології вантажних перевезень на різних рівнях, а також концепція реалізації технології ресурсозбереження в роботі транспортних вузлів на основі інформаційних систем. Для забезпечення взаємодії у транспортному вузлі на зміни різноманітних чинників необхідно врахування такої властивості системи, як адаптивність [7]. Проведені дослідження дозволяють зробити висновок про те, що низький рівень адаптації в структурах транспортної галузі та в системі ЦТС $€$ однією 3 головних зниження якості транспортного обслуговування на залізницях України [11]. Тому управління технологічним процесом у перевантажувальних вузлах повинно забезпечити процес адаптації внутрішніх та зовнішніх технологічних процесів між собою в тому числі - за рахунок впровадження інформаційно-керуючих систем.

Підвищення ефективності роботи залізнично-перевантажувального вузла в умовах застосування інформаційних логістичних технологій

Розглянемо у якості полігону дослідження залізничноперевантажувальних вузлів філії ЦТС, які у подальшому будемо позначати філія Е та філія В. Динаміку зміни обсягів вантажопереробки та переробки великовагових контейнерів філій наведено на рис. 1 та 2.

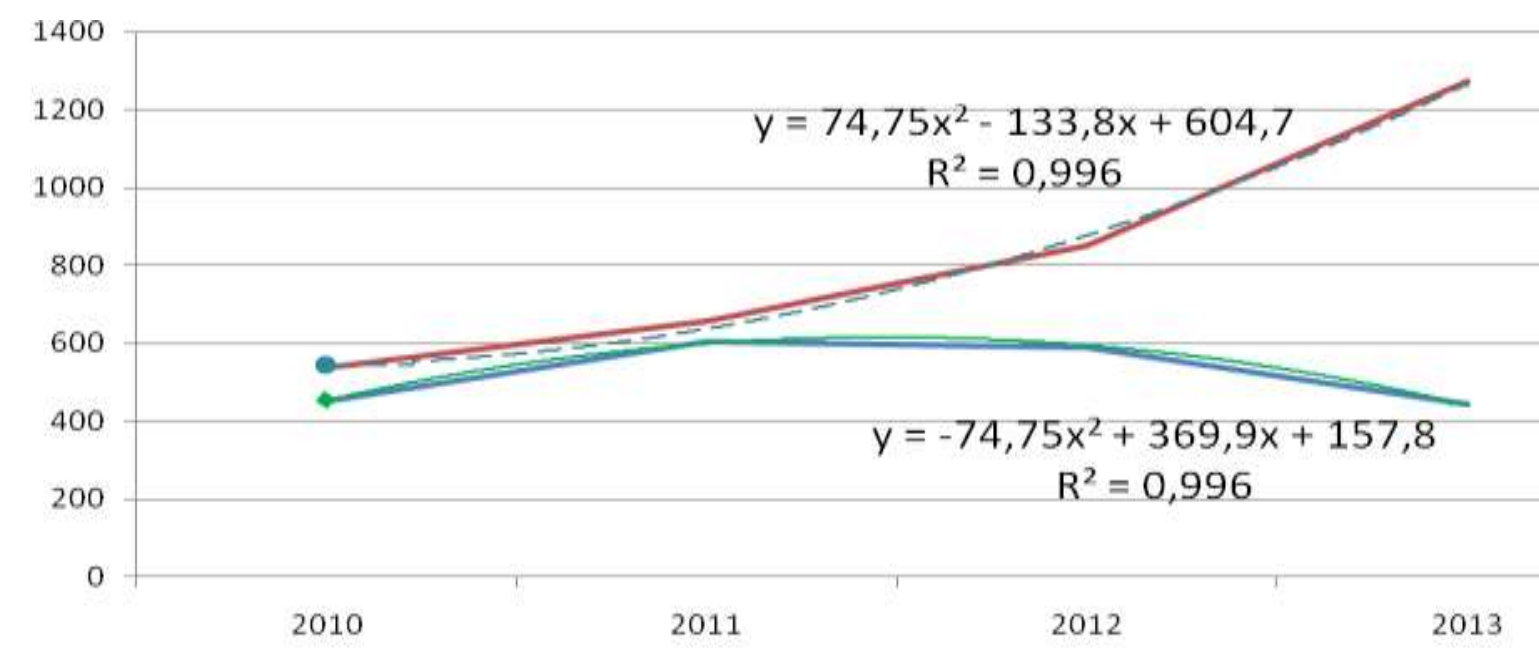

—— Обсяг вантажопереробки філії В, тис. т./рік

—_ Обсяг вантажопереробки філії Е, тис. т./рік

*_- Полиномиальная (Обсяг вантажопереробки філії В, тис. т./рік)

- - - Полиномиальная (Обсяг вантажопереробки філії Е, тис. т./рік)

Рис. 1 - Динаміка зміни обсягів вантажопереробки у філіях ЦТС 
Аналіз динаміки свідчить про наявність певної нерівномірності роботи та про перевагу обсягів роботи філії Е над філією В. Обсяг роботи філії Е має тенденцію до збільшення, що підтверджено результатами поліноміальної апроксимації даних. Максимальна добова переробка на філії Е становить 261 вагон, у тому числі для переробки контейнерів - 90 вагонів. Для філії В максимальна добова переробка складає 302 вагонів, у тому числі для переробки контейнерів - 67 вагонів.

Норма вантажної роботи щодоби встановлюється змінно-добовим планом, що складається на підставі затвердженого плану завезення, виходячи 3 наявності вантажу у вузлі на філії та на підходах до нього.

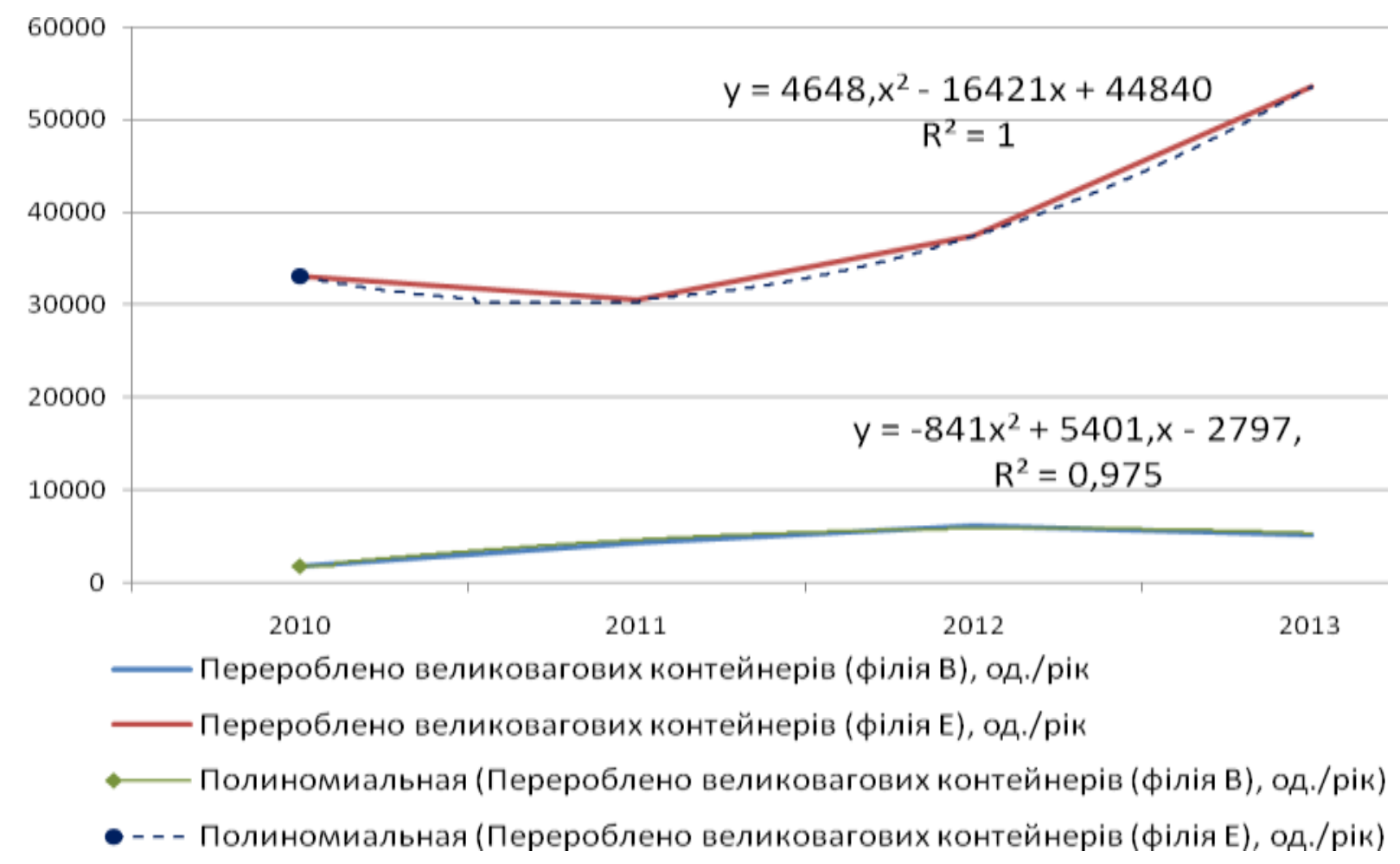

Рис. 2 - Динаміка зміни обсягів переробки великовагових контейнерів філій

В даний час філії сумісно із головним ЦТС при плануванні роботи дещо повільно здійснюють взаємодію із залізничним транспортом. Основна причина такої роботи - несвоєчасний підхід поїздів, подача вагонів та автотранспорту на перевантажувальні фронти. Обумовлено це достатньо низьким рівнем інформаційного забезпечення, через який планування щоденної роботи, а в остаточному підсумку і щомісячної, стає неможливим. Тому вважається за необхідним створення комплексної інформаційно-керуючої системи (IКC) на транспортному комплексі, яка б забезпечувала своєчасною інформацією всіх учасників перевізного процесу, зокрема філій та головного ЦТС.

Як свідчить аналіз тенденцій розвитку транспортного обслуговування і систем обробки інформації, інформаційний сервіс на транспорті повинен розвиватися в двох напрямках - він повинен надавати послуги як оперативним працівникам транспорту, так i його клієнтам.

Якість наданих послуг залежить насамперед від технологічних прийомів i засобів передачі інформації, використовуваних у управлінні процесом перевезень. У даний час стає очевидним, що окремими розрізненими заходами проблему підвищення якості інформаційної взаємодії не вирішити. Необхідна комплексна IКС, що передбачає безпомилковість передачі та обробки даних у межах єдиного інформаційного середовища порту та припортової станції.

Основні задачі інформаційних технологій роботи у перевантажувальному 
вузлі пов'язані 3 підвищення рівня якості експлуатаційної роботи шляхом автоматизації процесів управління та ув'язки до єдиного інформаційного середовища залізниці та автотранспорту, що відповідає логістичним принципам [10].

Основні функції ІКС, необхідні для досягнення мети:

- ведення скороченого графіка виконаного руху;

- $\quad$ ведення поїзного положення;

- $\quad$ робота ДГП із системою АСК ВП уз $€$;

- $\quad$ погоджене підведення вантажів та вагонів;

- інформаційна

підсистема взаємодії 3 митними і прикордонними органами, органами карантинного та фітосанітарного контролю.

Функціонально комплексна система електронного обміну даними складається із наступних набору АРM :

- АРМ оператора станційного технологічного центру по обробці поїздів ;

- АРМ маневрового диспетчера станції;

- АРМ товарного касира;

- АРМ прийомоздавача;

- АРМ представника ЦТС;

- АРМ технолога системи.

Важливим моментом при визначенні величини економії від експлуатації ІКС являється межа ефективності впливу технологічних факторів у процесі автоматизації. Критерієм ефективності ІКС перевантажувального вузла $€$ здатність системи найбільш повніше використовувати технологічні можливості залізниці.

Витрати на збирання, обробку та передавання інформації ручним способом

$$
E_{c}=E_{p}+E_{p \kappa}+E_{n o m},
$$

де $\boldsymbol{E}_{\boldsymbol{p}}$-витрати на збирання, обробку i передачу інформації ручним способом;

$\boldsymbol{E}_{\boldsymbol{p} \kappa^{-}}$поточні витрати при обробці інформації ручним способом 3 використанням клавішних машин;

$\boldsymbol{E}_{\text {nom- }}$ поточні витрати на обробку інформації ручним способом із залученням співробітників порту.

$$
E_{p}=12 \times N_{n e p} \times E_{3}+\mathrm{a}_{1} \times 365,
$$

де $N_{n e p^{-}}$кількість причетних робітників станції;

$\boldsymbol{E}_{3}$ - середня заробітна плата одного робітника;

$\mathrm{a}_{1}$ - вартість передачі інформації ручним способом.

$$
N_{n e p}=\left(\mathbf{w} 1+\mathbf{w}_{2}+\mathbf{w} 3\right),
$$

де w1- кількість прийомосдавальників;

w2 - кількість товарних касирів ;

w3-кількість операторів.

$$
\boldsymbol{E}_{\boldsymbol{p} \boldsymbol{\kappa}}=\mathrm{a}_{2} \times 365,
$$

де $\mathrm{a}_{2}$ - вартість передачі інформації 3 використанням клавішних машин.

$$
E_{\text {noM }}=12 \times N_{\text {noM }} \times E_{3}+a_{3} \times 365,
$$

де $\boldsymbol{N}_{\text {noм- }}$ кількість причетних робітників порту;

а 3 - вартість передачі інформації ручним способом із залученням співробітників ЦТС.

Величина поточних витрат при автоматизованому способі обробки інформації с використанням ІКС

$$
E_{a}=E_{3 \sigma}+E_{3 \kappa}+E_{a b}+E_{n \delta},
$$

де $\boldsymbol{E}_{3 \sigma}$ - витрати по ручному збиранню первинних даних;

$\boldsymbol{E}_{\text {зк }}$ - витрати на приготування , контроль та передачу вихідних даних 3 лінійногосподарських пунктів в пункт концентрації інформації, грн.;

$\boldsymbol{E}_{a b}-$ витрати на обробку інформації у IКС, грн.;

$\boldsymbol{E}_{\boldsymbol{n} \boldsymbol{d}}$ - витрати по автоматизованому передаванню даних до філій користувачам, грн.

В цілому зміни по поточні витратам складуть

$$
E_{n . b}=E_{c}-E_{a} .
$$

Сумарний річний ефект від застосування IKC, передавання та обробки інформації складе

$$
E_{p}=E_{n .6}+\Delta E_{e .6}-\kappa \times e_{H},
$$

де $\boldsymbol{\kappa}$ - капітальні вкладення на впровадження IKC, які складаються 3 вартості ЕОМ, додаткових каналів та кінцевих пристроїв у керуванні та на місцях; 
$\Delta \boldsymbol{E}_{\boldsymbol{e} \boldsymbol{6}^{-}} \quad$ оцінка покращення експлуатаційних витрати у перевантажувальному вузлі, складає 337739 грн./рік;

$\boldsymbol{e}_{\boldsymbol{H}}-$ нормативний коефіцієнт капітальних вкладень, 0.15 .

Термін окупності ЄІКС визначено за формулою

$$
\mathrm{t}_{0}=\frac{K}{\Delta E_{e . \beta}+E_{c}-E_{p}},
$$

де $\boldsymbol{E}_{\boldsymbol{n} \boldsymbol{b}}$ - додаткові витрати.

Для умов еревантажувального вузла отримані результати, які зведено у таблицю 1.

Таблиця 1

Визначення ефективності впровадження ІКС у перевантажувальних вузлах В та Е

\begin{tabular}{|c|c|c|c|}
\hline Вид витрат, грн.. & $\begin{array}{c}\text { Без } \\
\text { використання } \\
\text { ІКС }\end{array}$ & IKC & $\pm \Delta$ \\
\hline Капітальні вкладення & - & $\kappa=2418365$ & -2418365 \\
\hline $\begin{array}{l}\text { Витрати на } \quad \text { збирання } \\
\text { первинних даних }\end{array}$ & $\boldsymbol{E}_{\boldsymbol{p}}=417780$ & $\boldsymbol{E}_{3 \tilde{\sigma}}+\boldsymbol{E}_{3 \kappa}=944640$ & -526860 \\
\hline $\begin{array}{lll}\text { Витрати } & \text { на } & \text { обробку } \\
\text { iнформації } & & \end{array}$ & $\boldsymbol{E}_{p \kappa}=450630$ & $\boldsymbol{E}_{a b}=160903$ & 289727 \\
\hline $\begin{array}{lll}\text { Витрати на } & \text { передавання } \\
\text { iнформації } & & \end{array}$ & $\boldsymbol{E}_{\text {nos }}=483480$ & $\boldsymbol{E}_{\boldsymbol{n} \boldsymbol{d}}=80451$ & 403029 \\
\hline Загальні експлуатаційні витрати & $E_{c}=1351890$ & $E_{a}=1185994$ & $E_{n .6}=165896$ \\
\hline Загальні річні витрати & 1351890 & $E_{p}=1211010$ & \\
\hline Перероблено тон вантажу за рік & 241242 & 241242 & \\
\hline $\begin{array}{l}\text { Собівартість інформаційного } \\
\text { обслуговування, грн./т }\end{array}$ & 5,60 & 5,02 & $-0,58$ \\
\hline
\end{tabular}

Таким чином, термін окупності ІКС у перевантажувальних вузлах В та Е за формулою (9) складе

$$
\mathrm{t}_{\mathrm{o}}=\frac{2418365}{337739+1351890-1185994}=5.1 \text { рік. }
$$

При цьому у вигляді документів процес вантажоперевезення в межах IКC супроводжують наступні потоки (рис. 3):

вантажо i товаросупроводжувальних документів;

митних документів і інших дозволів, різного роду рознарядок і вказівок;

технологічні повідомлення про експлуатаційні події, які пов'язані з рухом транспортних коштів у штатних i позаштатних ситуаціях; спеціальні

повідомлення для вантажовласників (характеристики, місце розташування, стан вантажу).

\section{Висновки}

На підставі розглянутого можливо розробити комплекс програм, який передбачає автоматичний режим роботу у межах єдиного інформаційного середовища у перевантажувальних вузлах та головним ЦТС. 3 урахуванням проведених економічних розрахунків можливо виконувати перерозподіл засобів транспорту 
за умови врахування факторів, які впливають на нерівномірність перевезення вантажу, привести у відповідність з обсягами роботи контингент причетних працівників та впровадити логістичні технології взаємодії видів транспорту у вузлі.

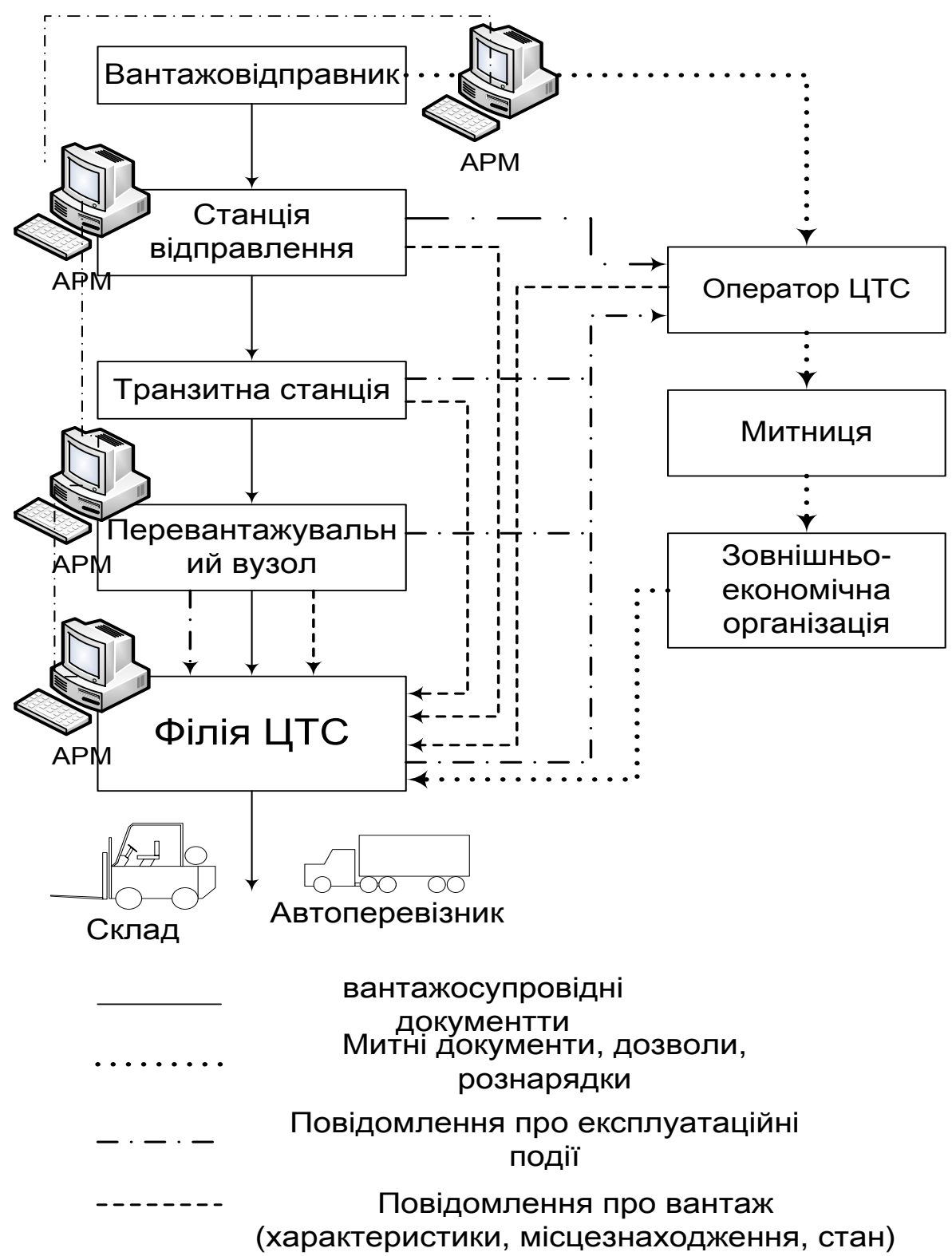

Рис. 3 - Структурно - функціональна схема інформаційно - керуючої системи у перевантажувальних вузлах

\section{Список використаних джерел}

1. Закон України «Про залізничний транспорт» [Текст] / Відомості ВР України. 1996.-№40.

2. Транспортна стратегія України на період до 2020 року [Електронний ресурс] : [Схвал. розпорядженням КМУ № 1555-р від 16.12 .2009 р.] - Режим доступу : http://www.mtu.gov.ua/ uk/discussion/15621.html/ 10.12.2009.

3. Council Directive 96/48/EC of 23 July 1996 on the interoperability of the transEuropean high-speed rail system [Text] / OJ: L 235, 17.9.1996.- p.6. 
4. УДЦТС Ліски [Електронний ресурс] : інформація. - Режим доступу : http://www.uz.gov.ua/about/general_information/entertainments/udtsts_liski/- (Дата звернення: 12.01.2015).

5. Бутько Т.В. Структурний поход к анализу припортового железнодорожного узла [Текст] / Т.В.Бутько, Д.В.Ломотько, Т.В. Головко // Сборник научных трудов по матеріалам международной научно-пратической конференции «Современные направления теоретических и прикладних исследований 2008». Транспорт.- Одесса: Черноморье, 2008. Том 1.- C. 19-21.

6. Бутько Т.В. Перспективи організації інформаційної взаємодії учасників перевезення в умовах залізнично-водних транспортно- логістичних вузлів [Текст] / Т.В.Бутько, Д.В.Ломотько // Залізничний транспорт України, 2007.- №6.- С. 62-65.

7. Данько М.I. Модель прогнозування розподілу порожніх вагонів на дирекції залізничних перевезень із застосуванням теорії нечітких множин [Текст] / M.I. Данько // $3 б$. Наук. праць. - Харків: УкрДАЗТ, 2005. - Вип. 71.

8. Альошинський Є.С. Аналіз передумов формування прикордонних транспортнологістичних кластерів для удосконалення міжнародних залізничних вантажних перевезень [Текст] / С.С. Альошинський, Г.Г.Замбрибор // Зб. наук. праць УкрДАЗТ. - Харків: УкрДАЗТ, 2014. - Вип. 150. - С. 11-17.

9. Альошинський Є.С. Повышение конкуретноспособности железнодорожного транспорта за счет создания транспортно-логистических кластеров [Текст] / Є.С. Альошинський, В.В. Мещеряков В.В.;Е.И. Рябовол [та ін.] // Восточно-Европейский журнал передовых технологий. - Харьков, 2013. - № 5/3 (65). - С. 39-45. 12

10. Ломотько Д.В. Совершенствование технологии распределения вагонов в условиях применения методов стимулирования линейных подразделений [Текст] / Д.В.Ломотько, Д.В. Каневская //Инновационный транспорт, 2012. -№ 2. -С. 3-7.

11. Бутько Т.В. Формування гнучкої системи логістичних ланцюгів доставки вантажу залізницями України [Текст] / Т.В. Бутько, Д.В. Ломотько, Д.І. Мкртичьян // СхідноЄвропейський журнал передових технологій.- Харків: Технологічний центр, 2006. - № 6/2(24). - C. 13-19.

Ломотько Денис Вікторович - д-р техн. наук, професор, кафедра транспортних систем та логістики Українська державна академія залізничного транспорту. Тел.: (057) 730-19-55. E-mail: den@kart.edu.ua

Волосюк Павел Федорович - магістр, Украӥнська державна академія залізничного транспорту. Тел.: (057) 730-19-55. E-mail: den@kart.edu.ua

Емець Іван Леонович - магістр, Українська державна академія залізничного транспорту. Тел.: (057) 730-19-55.E-mail: den@kart.edu.ua

Lomotko Denys Victorovich. - Doct. of techn. Sciences, Professor, Department of Transport Systems and Logistics Ukrainian State Academy of Railway Transport. Tel .: (057) 730-19-55. E-mail: den@kart.edu.ua

Volosyuk Pavlo Fedorovich - Master, Ukrainian State Academy of Railway Transport. Tel .: (057) 730-19-55. E-mail:den@kart.edu.ua

Emets Ivan Leonovich - Master, Ukrainian State Academy of Railway Transport. Tel .: (057) 730-19-55. Email: den@kart.edu.ua 
УДК 656.222.1

\title{
АНАЛІЗ ОСНОВНИХ ПРОБЛЕМ ПРИ ПЕРЕВЕЗЕННІ МАСОВИХ ВАНТАЖІВ ЗАЛІЗНИЧНИМ ТРАНСПОРТОМ
}

К-т техн. наук А.Л. Обухова, магістранти М.С. Шевельова, Н.О. Стешенко

\section{АНАЛИЗ ОСНОВНЫХ ПРОБЛЕМ ПРИ ПЕРЕВОЗКЕ МАССОВЫХ ГРУЗОВ ЖЕЛЕЗНОДОРОЖНЫМ ТРАНСПОРТОМ}

\author{
К-т техн. наук А.Л. Обухова, магистранты М.С. Шевелёва, Н.А. Стешенко
}

ANALYSIS OF THE MAIN PROBLEMS IN BULK TRANSPORT BY R

Cand. of techn. sciences. A. Obukhova, master student M. Shevelova, N.A. Steshenko

В статті, на основі наведеної статистики, визначена доля масових вантажів, які перевозяться залізнииями Украӥни, особливості умов утворення вантажопотоків масових вантажів. Також визначені найбільш актуальні проблеми пов'язані з перевезенням масових вантажів $і$ запропоновані шляхи їх вирімення, з урахуванням вимог сучасних інформаційних $i$ транспортних технологій.

Ключові слова: масовий вантаж, маршрутне відправлення, порожній вагон, тариф.

В статье, на основании приведенной статистики, определена доля массовых грузов перевозимых железными дорогами Украины, особенности условий образований грузопотоков массовых грузов. Также определены наиболее актуальныле проблемы, связанные с перевозкой массовых грузов и предложены пути их решения, с учетом требований современных информачионных и транспортных технологий.

Ключевые слова: массовый груз, маршрутная отправка, порожний вагон, тариф.

When transporting bulk cargo by rail raises a number of issues that will melt on the way optimal performance industrial and transportation systems. In this paper, based on the above statistics, the proportion determined bulk transported by railways of Ukraine, especially the conditions of formation of cargo flows of bulk. Also identified the most pressing problems related to the carriage in bulk, and ways to solve them, to meet the requirements of modern information and transportation technologies. The analysis of the shortcomings of the method of forming routes for the carriage of bulk: Timely provision of supply of empty wagons, rational use of the park empty wagons, tariffs in organizing the route deliveries.

Keywords: bulk cargo, full train, empty wagon, tariff.

Вступ. Залізничний транспорт України є невід'ємною ланкою в стабільній та безперервній роботі промислових галузей країни, забезпечує внутрішні та зовнішні транспортно-економічні зв'язки. Наявні технологічні процеси роботи підприємств промислових галузей утворюють як вхідні (сировина для потреб підприємства) так і вихідні (продукція підприємства) потоки масових вантажів освоєння яких покладено на залізничний транспорт [10].

Постановка проблеми. При перевезенні масових вантажів залізницею виникає ціла низка проблем, що встає на перешкоді оптимальній роботі транспортно- промислової системи. Ці проблеми вимагають вирішення сучасними методами, задля збереження конкурентоспроможності та підвищення інвестиційної привабливості залізничного транспортну на ринку транспортних послуг.

Аналіз останніх досліджень і публікацій. Проблемі маршрутизації значне місце приділено у працях В.М. Акулінічева та Н.Е. Борового. В [1, 3] ефективність маршрутизації проявляється у зіставленні їі 3 немаршрутним відправленням вантажів, у зв'язку з цим до неї включають тільки ті збереження та втрати, які відрізняються при цих способах організації вагонопотоків. У 
цих випадках маршрутизація економічно доцільна, якщо збереження більше втрат i економічний ефект виражається різницею цих двох величин.

Визначення мети та задачі дослідження. Метою дослідження $\epsilon$ виявлення та аналіз основних загальних проблем перевезення масових вантажів на залізницях України, пошук та опис шляхів та методик їх вирішення.

Основна частина дослідження. Незважаючи на зменшення обсягів перевезень у внутрішньому сполученні, перевезено 182,6 млн тонн, імпортні перевезення становлять 36,2 млн тонн, експортні - 141,3 млн тонн, транзитні - 29,5 мЛн тонн [9].

Переважну частку номенклатурних груп, що перевозяться залізницями України складають такі вантажі як: мінеральні добрива, будівельні матеріали, кам'яне вугілля та руди, зокрема залізні. Важливе місце займають також різноманітні метали і нафтові вантажі [5]. Відсоткове співвідношення номенклатурних груп наведене у табл. 1

Таблиця 1

Перелік номенклатурних груп та вантажів, що перевозяться залізничним транспортом

\begin{tabular}{|l|c|c|}
\hline \multicolumn{1}{|c|}{ Найменування вантажу } & $\begin{array}{c}\text { Відсоток в обсязі } \\
\text { перевезень }\end{array}$ & Спосіб перевезення \\
\hline 1. Кам'яне вугілля & 27,0 & Навалом \\
\hline 2. Руда залізна та марганцева & 18,1 & Навалом \\
\hline 3. Мінбудматеріали & 15,1 & Навалом \\
\hline 4. Чорні метали & 9,3 & Навалом \\
\hline 5. Нафта та нафтопродукти & 6,8 & Наливом \\
\hline 6. Зерно та продукти мелення & 2,6 & Насипом \\
\hline 7. Хімічні та мінеральні добрива & 2,6 & Навалом \\
\hline 8. Кокс & 2,6 & Навалом \\
\hline 9. Хімікати & 2,2 & по-різному \\
\hline 10. Брухт чорних металів & 2,1 & Навалом \\
\hline 11. Цемент & 1,2 & Навалом \\
\hline 12. Руда кольорових металів & 1,0 & Навалом \\
\hline 13. Лісні вантажі & 0,6 & Навалом \\
\hline 14. Машини та обладнання & 0,1 & по-різному \\
\hline 15. Кольорові метали і вироби & 0,1 & Навалом \\
\hline 16. Гнші вантажі & 8,6 & по-різному \\
\hline
\end{tabular}

Згідно з табл. 1 майже 85 \% обсягу перевезень - це вантажі перших восьми найменувань. Приблизно $80 \%$ вантажів перевозять навалом (без рахунку місць) у відкритому рухомому складі, близько $7 \%$ наливом у цистернах, $3 \%$ - насипом у закритому рухомому складі, а решту $10 \%-$ різними, у тому числі й названими вище способами [7].

Основними вантажоформуючими підприємствами $є$ представники добувної, хімічної, машинобудівної та металургічної промисловості що користуються послугами приватних залізничних операторів та операторів, що входять до структури «Укрзалізниці».

До основних проблем при перевезенні масових вантажів можна віднести: економічну недосконалість маршрутних відправок; неефективне використання порожніх вагонопотоків, для забезпечення освоєння заявлених обсягів; забезпечення схоронності перевезень масових вантажів у прямому та міждержавному сполученнях, затримка вантажовідправником (вантажоодержувачем) рухомого складу та інші фактори.

Однією 3 переваг перевезень масових вантажів $\epsilon$ можливість формування 
маршрутних відправок. Але метод маршрутизації перевезень має як переваги, так i недоліки. Зокрема, в «Інструктивних вказівках 3 організації вагонопотоків на залізницях України» [6] говориться, що достатньою для включення в план маршрутизації окремої кореспонденції вантажів є така умова: додаткові витрати на організацію маршрутів, порівняно 3 немаршрутним відправленням на станції навантаження $\Delta E_{c н(i j)} \mathrm{i}$, якщо маршрути прямі, також на станції вивантаження $\Delta E_{c в(i j)}$, не повинні перевищувати економії на шляху $\Delta E_{\text {јек }}$ пря (ij прямування) за кожним $j$-м призначенням 3 потужністю вагонопотоку $i$, що визначається за формулою

$$
\Delta E_{c н(i j)}+\Delta E_{c в(i j)} \leq \Delta E_{\text {ек(ij) }}^{\text {прям }}
$$

Раніше зацікавленість вантажовласників i залізниці в частині маршрутизації вагонопотоків об’єднувались планом перевезень та планом маршрутизації навантаження як його основної складової. Але ж на даному етапі існують протиріччя між інтересами залізниць, вантажовідправниками та операторамивласниками вантажних вагонів. Наприклад, якщо Укрзалізниці у цілому вигідно формувати відправницькі маршрути і 3 технологічної, і з економічної точки зору, то залізниця відправлення маршруту недоотримує доходи, оскільки поправковий коефіцієнт до базового тарифу передбачає зменшення провізних платежів при маршрутизації у порівнянні 3 тарифом за вагонні відправки, а механізму перерозподілу між залізницями експлуатаційних витрат та економії, що виникає на шляху прямування через скорочення переробки вагонів на технічних станціях, немає. Звідси і прагнення залізниць відправлення маршрутів оформити перевізні документи на вантажі, що прямують маршрутами, як на вагонні відправки. Отже економічна ефективність маршрутизації для залізниці, 3 огляду на тарифні умови, можлива тільки при певному обсязі добового вантажообігу. у [2] запропоновано компенсувати витрати залізниці за рахунок додаткового доходу від формування маршрутних відправок на коліях загального користування.

$$
D_{\partial о д}{ }^{\prime}=e_{\text {форм }} \cdot Q_{м}
$$

де $e_{\text {форм }}$ - ставка збору за формування відправницьких маршрутів на коліях загального користування силами та засобами залізниці, грн/т;

$$
Q_{м}{ }^{\text {нетто }} \text { - вага маршруту нетто, т. }
$$

Процес підвищення рівня доставки вантажів можливий за рахунок зменшення кількості переробок вагонів при виконанні місцевої роботи. Це можна досягнути при більш широкому використанні маршрутизації - як відправницької, так i ступінчатої, що, у свою чергу, досягається оптимальною організацією місцевої роботи сумісно з оперативним плануванням або при календарному навантаженні вантажовідправниками груп вагонів, а також при взаємодії всіх підрозділів, що беруть участь у перевізному процесі.

Окремим недоліком маршрутизації при перевезенні масових вантажів постає неефективне використання парку порожніх вагонів. В сучасних економічних та ринкових умовах, в умовах значної присутності вагонів власності приватних залізничних операторів на ринку, значна їх кількість рухається по кільцевим маршрутам [4]. Використання кільцевих маршрутів призводить до збільшення коефіцієнту порожнього пробігу вагонів, i як наслідок погіршення основних кількісних та якісних показників роботи залізниці. До засобів зменшення значення порожнього пробігу, та підвищення економічної ефективності маршрутизації масових вантажів можна віднести:

- тарифне стимулювання маршрутних відправок порожніх вагонів;

- оптимізація кількості операторів по кожній великій навантажувальній станції;

- перехід від непереривного прийому заявок к місячному плануванню перевезень порожніх вагонів;

- застосування технології здвоєних операцій.

Основним ефектом від використання маршрутизації порожніх вагонопотоків $\epsilon$ збільшення маршрутної швидкості поїздів, що сприяє виконанню залізницею термінів 
доставки вантажів. Зокрема маршрутизація порожніх вагонопотоків сприяє:

вагонів; скороченню парку вантажних

- скороченню капітальних вкладень на розвиток парку вантажних вагонів;

- скороченню амортизаційних відрахувань на парк вантажних вагонів;

- скороченню витрат на переробку вагонопотоку на технічних станціях;

- скороченню кількості пошкоджень вагонів в результаті сортування на гірці та інше.

Також однією із поширених проблем в перевезеннях масових вантажів $є$ задача своєчасного забезпечення перевізниками, власниками рухомого складу, навантажувальними ресурсами, особливо його дефіцитним родом напіввагонів та іншими спеціальними вагонами. Проаналізувавши вагонний парк Укрзалізниці, можна визначити одну 3 причин, яка сприяла виникненню нестачі порожніх вагонів. Значна кількість підприємств, які користуються вагонами Укрзалізниці, не виконують норм, які відведені на навантажувальні операції. За даними Укрзалізниці, близько 35,9 \% вагонного парку стоїть на під'їзних коліях в очікуванні навантажувальних операцій, під обробкою на технічних станціях знаходиться близько $37,1 \%$, на проміжних станціях знаходиться близько $6 \%$ і всього $21,3 \%$ знаходяться у русі (рис. 1).
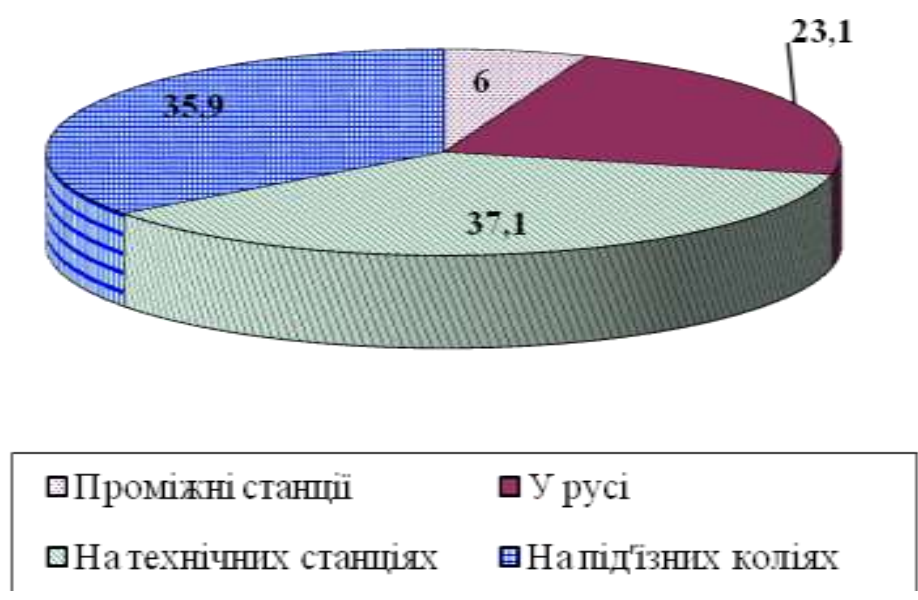

Рис. 1. Діаграма розподілу часу затримки вагонів

Уникнути виникнення подібних ситуацій можливо за рахунок удосконалення процесу перевезень 3 використанням нових інформаційно-керуючих систем, що призведе до оптимізації використання порожніх вагонів i, як наслідок, отримання зростання доходів залізниць та уникнення збитків через виплату штрафів [8].

\section{Висновки 3 дослідження i} перспективи, подальший розвиток у даному напрямку. При розгляді специфіки перевезень масових вантажів більш актуальними проблемами виявились маршрутизація вантажів, своєчасне забезпечення вантажовідправників порожніми вагонами у необхідних обсягах

та загалом неефективність використанні вагонного парку залізниць. А проблема забезпечення порожніми вагонами полягає в тому що, значна кількість вагонів які знаходяться на під’їзних коліях чекають виконання 3 ними операцій.

Крім того, недосконала тарифна політика викликає протиріччя між інтересами залізниць, вантажовідправниками та операторами-власниками вантажних вагонів, що також призводить до зменшення зацікавленості по відношенню до маршрутних відправок.

Одним 3 варіантів уникнення простоїв порожніх вагонів $є$ удосконалення процесу перевезень з використанням нових інформаційно-керуючих систем.

В статті наведено аналіз проблематики відправки масових вантажів. Однак враховуючи актуальність дане питання потребує подальшого дослідження та розгляду відповідно до отриманих висновків. 


\section{Список використаних джерел}

1. Акулиничев, В.М. Организация вагонопотоков и маршрутизация перевозок [Текст] / В.М. Акулиничев, О.С. Кирьянова, Н.Е. Боровой. - М.: Изд-во «Транспорт», 1970. $320 \mathrm{c}$.

2. Богомазова, Г.Є. Удосконалення методів визначення ефективності маршрутизації перевезень з урахуванням сучасних вимог [Текст] / Г.С. Богомазова // Збірник наукових праць Української державної академії залізничного транспорту . - 2013. - Вип. 137. - С. 105109.

3. Боровой, Н.Е. Маршрутизация перевозок грузов [Текст] / Н.Е. Боровой. - М.: Транспорт, 1978. - 216 с.

4. Верлан, А. І. Підвищення ефективності управління приватним вагонним парком за рахунок відправницької маршрутизації порожніх вагонопотоків [Текст] / А. І. Верлан, Д. М. Козаченко, Р. В. Вернигора // Залізн. трансп. України. - 2012. - № 6. - С. 35-37.

5. Железнодорожный транспорт Украины: характеристика отрасли [Електронний pecypc]. - Режим доступу: http://transportinform.com/rail-transportation/501-zheleznodorozhnyitransport-ukrainy.html.

6. Інструктивні вказівки з організації вагонопотоків на залізницях України [Текст]: наказ Укрзалізниці від 29.12.2004 р. № 1028-ЦЗ - К.: Вид-во ТОВ «Швидкий рух», 2005. $100 \mathrm{c}$.

7. Нестеренко, Г.І. Визначення параметрів вагонопотоків з навальними вантажами на залізницях України [Текст] / Г.І. Нестеренко // Вісник Академії митної служби України. Серія : Технічні науки. - 2014. - № 1. - С. 80-85.

8. Рибальченко, Л.І. Оптимізація використання порожніх вагонів в умовах дефіциту рухомого складу [Текст] / Л.І. Рибальченко, Д.В. Франковський // Збірник наукових праць Української державної академії залізничного транспорту . - 2014. - Вип. 145. - С. 69-73.

9. У грудні 2014 року Укрзалізниця перевезла 29,4 млн тонн вантажів [Електронний pecypc] // Офіційний сайт Міністерства інфраструктури України. - Режим доступу: http://www.mtu.gov.ua/ru/news/47330.html.

10. Укрзалізниця. Вантажні перевезення [Електронний ресурс]. - Режим доступу: http://uz.gov.ua/cargo_transportation/.

Рецензент д-р техн. наук, професор Д.В.Ломотько

Обухова Анна Леонідівна, канд. техн. наук, дочент кафедри управління вантажною і комериійною
роботою Украйнська державна академія залізничного транспорту. Тел.: (057) 730-10-85. E-таі: uvkr@kart.edu.ua

Шевельова Маріанна Сергї̈на, магістр, кафедра управління вантажною $і$ комериійною роботою Украӥнська державна академія залізничного транспорту. Тел.: (057) 730-10-85. E-mail: uvkr@kart.edu.ua

Стешенко Наталія Олександрівна, магістр, кафедра управління вантажною $і$ комериійною роботою Украӥнська державна академія залізничного транспорту. Tел.: (057) 730-10-85. E-mail: uvkr@kart.edu.ua

Anna Obukhova, lecturer, department of Management of cargo and commercial work Ukrainian State Academy of Railway Transport.Tel.: (057) 730-10-85. E-mail: uvkr@kart.edu.ua

Shevelova Marianna, master, department of Management of cargo and commercial work Ukrainian State Academy of Railway Transport.Tel.: (057) 730-10-85. E-mail: uvkr@kart.edu.ua

Steshenko Nataliya, master, department of Management of cargo and commercial work Ukrainian State Academy of Railway Transport.Tel.: (057) 730-10-85.E-mail: uvkr@kart.edu.ua 
УДК 656.212.5.001.76

\title{
УДОСКОНАЛЕННЯ РОБОТИ ТЕХНІЧНОЇ СТАНЦІЇ В УМОВАХ НЕРІВНОМІРНОСТІ ВАГОНОПОТОКУ
}

\author{
К-т. техн. наук О.А. Малахова, магістрант М.І. Князсва
}

\section{СОВЕРШЕНСТВОВАНИЕ РАБОТЫ ТЕХНИЧЕСКОЙ СТАНЦИИ В УСЛОВИЯХ НЕРАВНОМЕРНОСТИ ВАГОНОПОТОКА}

\author{
К-т. техн. наук О.А. Малахова, магістрант М.І. Князєва
}

\section{IMPROVING THE WORK OF TECHNICAL STATIONS UNDER CONDITIONS OF NON- UNIFORM STREAM OF WAGONS}

\section{Cand. of techn. sciences. O.A. Malakhova, master student M. Knyazeva}

Зменшення нерівномірності перевезень має найважливіше значення як для залізниці, так і для підприємств, щчо вона обслуговує. Досягнути повну рівномірність навантаження та руху поїздів неможливо, внаслідок об'єктивного характеру нерівномірності, але значно підвищитти рівень рівномірності можливо. Запропоновані заходи зменшення нерівномірності у просторі та часі для різних підсистем технічних станцій.

Ключові слова: станція, нерівномірність, вагонопотік, розформування, формування.

Уменьшение неравномерности перевозок имеет важнейшее значение как для железной дороги, так и для предприятий, которые она обслуживает. Достичь полной равномерность погрузки и движения поездов невозможно, вследствие объективного характера неравномерности, но значительно повысить уровень равномерности возможно. Предложень меры для уменьшения неравномерности в пространстве и времени для различных подсистем технических станциий.

Ключевые слова: станция, неравномерность, вагонопоток, расформирование, формирование.

The reduction in traffic has negatively affected the performance of the railways. Efficient use of transport infrastructure possible while reducing the non-uniformity of the transportation process. The decrease in non-uniformity of traffic is essential for the railway, and for businesses that it serves. Achieve complete uniformity of loading and movement of trains is impossible due to the uneven nature of the objective, but significantly increase the level of uniformity possible.

The measures to reduce non-uniformity in space and time for the various subsystems of technical stations. When passing through the technical station wagon there is an alignment between the intervals defined flow of applications that allows you to align the intervals between trains.

Keywords: station, non-uniform, stream of wagons, disbanding, forming.

Вступ. Залізничний транспорт $75 \%$ вантажооборота $\quad$ i $\quad 40 \%$ відіграє величезну роль в економіці нашої пассажирооборота виконується залізничним країни. Від його роботи залежить транспортом загального користування. нормальний розвиток i функціонування підприємств промисловості, сільського господарства, постачання і торгівлі. Тому, головними завданнями залізниць $\epsilon$ комплексний розвиток і підвищення ефективності використання транспортних засобів, прискорення доставки вантажів та збільшення швидкості руху поїздів. Понад

Головним завданням удосконалення управління перевізним процесом $є$ перехід до якісного транспортного обслуговування, орієнтованого на задоволення вимог користувачів, при досягненні найбільшої економічної ефективності від запропонованих технологічних рішень. 
Постановка проблеми. Незважаючи на значне зниження обсягів перевізної роботи i вивільнення виробничих потужностей, існуюча технологія перевізного процесу не зазнала принципових змін.

Основним негативним фактором в експлуатаційній роботі залізниць $\epsilon$ нерівномірність у просторі й у часі.

В умовах нерівномірності вагонопотоку виникає цілий ряд труднощів, які перешкоджають управлінню поїзної роботи. Тому, необхідно завдяки сучасним методам та аналізу роботи знаходити оптимальні та оперативні рішення для усунення планування та управління вагонопотоками, в тому числі на технічних станціях.

Мета і задачі дослідження. Процес вирішення поставленої проблеми включає розгляд наступних завдань:

- аналіз процесу переміщення поїздота вагонопотоків 3 метою встановлення характеру зміни нерівномірності у просуванні;

- виявлення основних ланок у загальній системі просування та переробки поїздо- і вагонопотоків, в яких відбувається збільшення нерівномірності;

- розробка технологічних рішень, спрямованих на зниження нерівномірності в

просуванні та

переробці

поїздо-

вагонопотоків;

- встановлення характеру взаємного

впливу в роботі технічних станцій та залізничних дільниць та розробка заходів зі скорочення такого впливу на перевізний процес.

Виклад основного матеріалу. Падіння обсягів перевізної роботи автоматично призвело до зниження розмірів переробки вагонів на залізничних станціях, головним чином - на сортувальних станціях, які визначають характер процесу функціонування всієї залізничної мережі.

В період 32008 по 2013 роки середньодобові розміри переробки транзитних вагонів, що проходять сортувальні станції 3 переробкою і без переробки, знизилися приблизно в два рази.

Зменшення розмірів перевізної роботи призвело до вивільнення виробничих потужностей i, насамперед, колійного розвитку залізничних станцій. Незважаючи на це вивільнення, не відбулося будь - яких істотних змін в якісних показниках роботи залізниць. Так, наприклад, практично не зазнал змін такий важливий показник роботи сортувальних станцій, як середній простій транзитного вагона без переробки, а простій транзитного вагона 3 переробкою зріс майже у двічі. Дані за звітний період наведені на рис. 1.
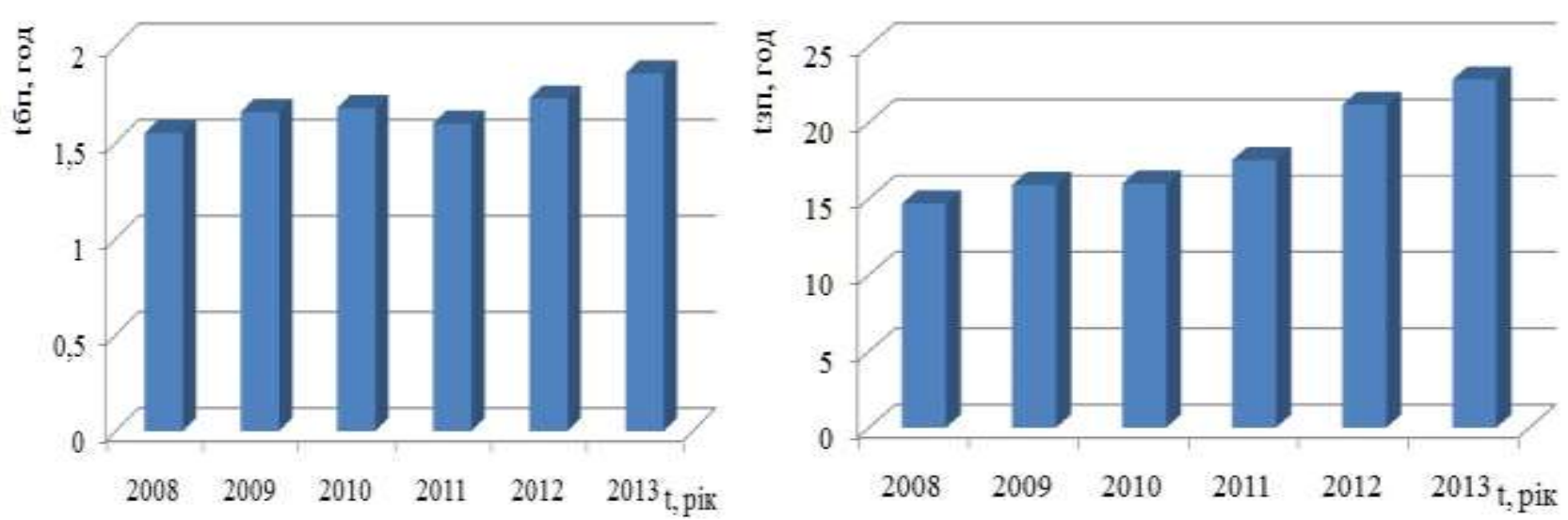

Рис.1. Аналіз простою транзитних вагонів на станції: а - без переробки; б - 3 переробкою

Питаннями раціоналізації узгодження графіка руху поїздів з технологією роботи технічних станцій, як важливого чинника удосконалення експлуатаційної роботи, присвячені дослідження великого числа вчених:
Б. Е. Пейсахзона, 
М. Д. Іловайського,

Б. М. Максимовича,

М. Д. Крюкова,

Є. В. Архангельського,

В. І. Некрашевича, В. К. Буянової та інших дослідників.

Ними були запропоновані різні способи удосконалення системи пропуску та переробки поїздо- та вагокопотоків, розроблені теоретичні основи взаємодії в роботі станцій і дільниць, у тому числі і принципи узгодження графіка руху поїздів 3 роботою станцій. Разом 3 тим необхідним $є$ розвиток досліджень природи зародження нерівномірності поїздо- і вагонопотоків, а також розроблення рекомендацій щодо іiі зниження на основі реалізації будь-яких технологічних рішень.

Аналіз нерівномірності поїздо- та вагонопотоків довів, що перевезення вантажів здійснюються протягом року нерівномірно. Обсяг перевезень по кварталах неоднаковий - зазвичай він мінімальний у першому кварталі, максимальний у другому i на середньорічному рівні - в третьому. Помісячний обсяг перевезень також $\epsilon$ нерівномірним: мінімум спостерігається у січні - лютому, максимум - у квітні, жовтні та грудні. Однак, за родами вантажів ці закономірності можуть не виконуватися [1].

Нерівномірність перевезень може залежати від сезонності виробництва, наприклад, по продукції сільського господарства. Для зниження нерівномірності перевезень сільськогосподарських вантажів планується розширення складської й елеваторної мережі, спорудження консервних, овочесушильних i інших заводів. Проте нерівномірність перевезень сільськогосподарських вантажів усе ще дуже значна.

Іншим фактором, що визначає нерівномірність перевезень, $€$ сезонність споживання. Це відноситься, наприклад, до споживання рідкого палива, мінеральних добрив, використання машин i запасних частин у сільському господарстві, витрати палива на побутові потреби, перевезення для потреб залізниць.

$\begin{array}{ccr}\text { При } & \text { розрахунках } & \text { підсумкової } \\ \text { величини } & \text { коефіцієнта } & \text { місячної }\end{array}$

нерівномірності варто встановити розподіл перевезень кожного з основних вантажів по місяцях. При цьому періоди збільшення перевезень для одних сезонних вантажів можуть бути періодами скорочення для інших. Наприклад, у період збільшення перевезень хлібних вантажів скорочуються перевезення будівельних матеріалів, вугілля і руди [2].

Нерівномірність перевезень за часом характеризується коефіцієнтом нерівномірності - відношення обсягу перевезень максимального місяця до середньомісячного їхнього обсягу [3].

Коефіцієнт нерівномірності визначається за формулами:

$$
K_{\text {нер }}^{u^{\prime}}=\frac{\sum P_{\max }^{\text {мiс }}}{\sum \overline{P_{\text {мiс }}}},
$$

де $\sum P_{\max }^{\text {мiс }}-$ максимальний місячний обсяг перевезення, т;

$\sum \overline{P_{\text {мiс }}}$ - середньомісячний обсяг перевезення, т.

$$
K_{\text {нер }}^{\text {нч }}=\frac{\sum P_{i}}{\sum \bar{P}}
$$

де $\sum P_{i}$ - обсяг перевезення кожного місяця, $\mathrm{T}$

$$
\sum \bar{P} \text { - середньомісячний обсяг }
$$
перевезення, т.

$$
K_{\text {нер }}^{\text {нче }}=\frac{\sum P_{\max }}{\sum P_{\min }},
$$

де $\sum P_{\max }$ - максимальний місячний обсяг перевезення, т;

$\sum P_{\min }$ - мінімальний місячний обсяг перевезення, т.

Коефіцієнт нерівномірності, розрахований за формулами 1 та 3 завжди більше 1 і лише у випадках ідеально рівномірного перевезення дорівнює 1 .

Коефіцієнт нерівномірності, розрахований за формулою $2, \epsilon$, по суті, так званим індексом сезонності, отже може бути як більше, так і менше 1 [1]. 
Нерівномірність перевезень за часом пов'язана із сезонним виробництвом i споживанням багатьох видів продукції, неритмічною роботою підприємстввантажовласників, наявністю вихідних i святкових днів. Чим вище нерівномірність перевезень у часі, тим більші резерви всіх ресурсів

(матеріальних,

трудових, фінансових) повинен мати залізничний транспорт для виконання своєї функції [3].

Дані з розрахунку індексу сезонності при відправленні вагонопотоків 3 технічної станції наведені на рис. 2.

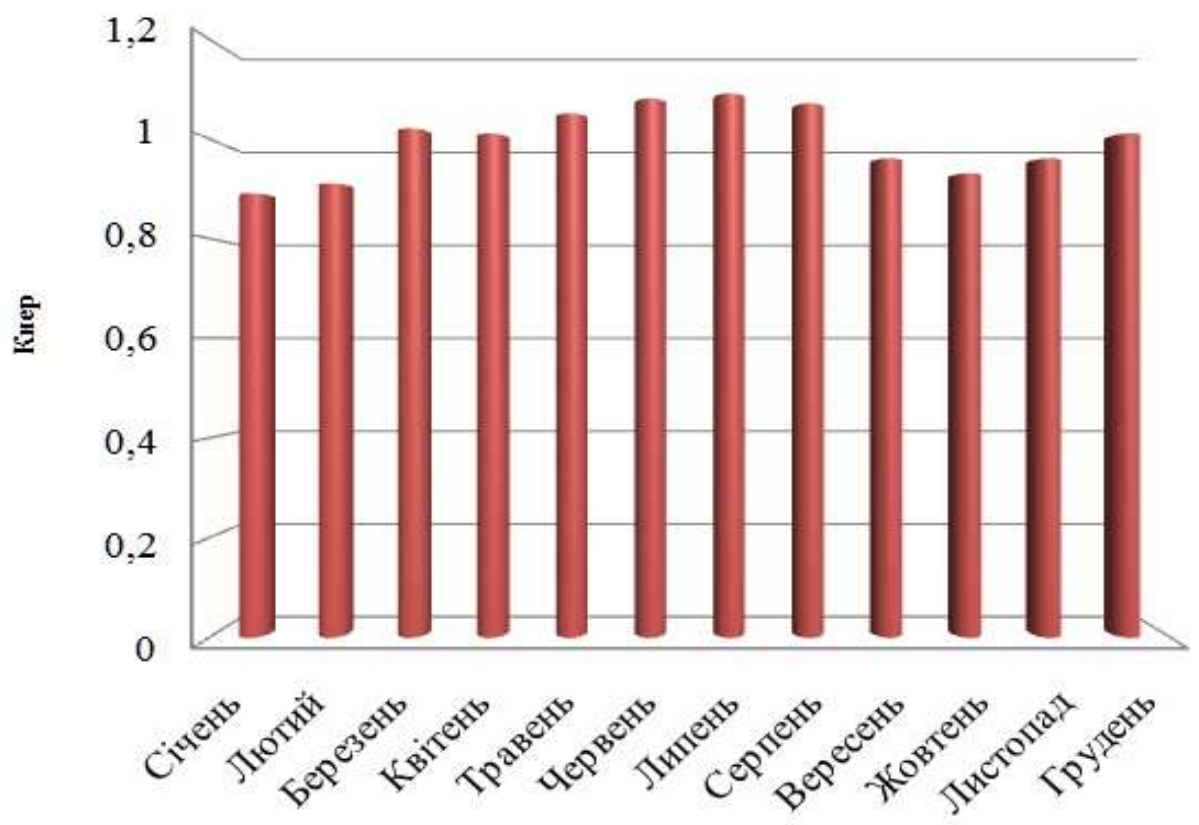

Рис.2. Аналіз індексу сезонності при відправленні вагонопотоків з технічної станції

Нерівномірність перевезень у просторі може характеризуватися коефіцієнтом зворотності, який визначається за формулою

$$
K_{\text {нер }}^{\text {зв }}=\frac{\sum P_{n о p}}{\sum P_{\text {зав }}},
$$

де $\sum P_{\text {nор }}$ - обсяг перевезення вантажів у переважному напрямку, т;

$\sum P_{\text {зав }}$ - обсяг перевезення вантажів у непереважному напрямку, т.

Під переважним напрямком розуміють напрямок зі значним вагонопотоком, а зворотній напрям непереважним

Коефіцієнт зворотності менше 1 і може бути рівним 1 лише у випадку однакової щільності вагонопотоку за напрямками [1].

Чим ближче обидва наведених коефіцієнта до одиниці, тим більш раціонально використовуються ресурси залізничного транспорту. Тим не менше, зовсім усунути нерівномірність перевезень неможливо, тому іï необхідно враховувати в економічних розрахунках для своєчасного створення запасів відповідних ресурсів [3].

Нерівномірність вагонопотоків на технічних станціях збільшує міжопераційні простої у різних підсистемах.

Для зниження міжопераційних простоїв вагонів в підсистемі «парк прийому - сортувальна гірка» передбачаються додаткові виробничі потужності (колійний розвиток, технічне оснащення сортувальної гірки тощо), які відіграють своєрідну роль «буфера» та зменшують негативні наслідки, що викликають нерівномірність просування вагонопотока [4]. При цьому чим вище рівень нерівномірності, тим більше передбачається запас виробничих потужностей.

По мірі просування в підсистемі «прилеглий перегін - парк прийому - гірка" відбувається трансформація проходження составів через елементи станції у часі. На сортувальну гірку состави надходять 3 
коефіцієнтом варіації $\gamma_{2}=0,3 \div 0,4$. Таким чином, на початковому етапі відбувається згладжування нерівномірності просування составів в межах станції.

Інтервали між моментами завершення накопичення вагонів у состави поїздів розподілені по показовому закону. Основна причина такого факту криється у вимозі формування повносоставних вантажних поїздів.

Остання підсистема сортувальної станції «витяжки формування - парк відправлення - прилеглий перегін», так само як і перша, грає роль своєрідного «буфера», трансформує просування вагонопотока в часі i також вимагає створення додаткових виробничих потужностей через нерівномірність надходження вимог на обслуговування.

Таким чином, на всіх етапах просування вагонопотока по станції (за винятком процесу завершення накопичення вагонів у сортувальному парку) його нерівномірність регулюється за допомогою обслуговуючих апаратів, що мають певну пропускну i переробну спроможність. Зменшити вплив нерівномірності на роботу технічної станції у другій групі можливо при впровадженні формування поїздів за наявними певними відхиленнями величини составів від середнього значення.

Масове моделювання процесу составоутворення при різних значеннях зазначених вихідних параметрів показало відсутність впливу інтенсивності вхідного вагонопотоку на гірку на коефіцієнт варіації інтервалів між моментами закінчення накопичення складів. Одночасно на величину цього коефіцієнта має великий вплив співвідношення величин розформованих та сформованих составів, а також нерівномірність їх надходження на станцію.

Висновок. Незважаючи на істотне зниження обсягів перевізної роботи i вивільнення виробничих потужностей, не відбулося кардинальних покращень у роботі залізниць. Як i раніше спостерігаються великі міжопераційні простої рухомого складу, зросло його нераціональне використання, порівняно великими залишаються паливно-енергетичні витрати. Аналіз теорії і практики роботи залізничного транспорту в частині пропуску та переробки поїздо- i вагонопотоків показав, що головною причиною, яка викликає зростання експлуатаційних витрат, $\epsilon$ нерівномірність вагонопотоків за величиною й у часі.

При проходженні вагонопотока через підсистеми обслуговування відбувається його трансформація у бік вирівнювання інтервалів між окремими вимогами Цілеспрямований вплив на процес зниження нерівномірності просування поїздо- i вагонопотоків можливий на стадії закінчення формування составів у сортувальному парку. Дана дія реалізується у технології, заснованій на завершенні накопичення одного складу після розформування чергового составу на сортувальній гірці при відсутності перелому ваги поїзда.

\section{Список використаних джерел}

1 Неравномерность грузовых перевозок [Електронний ресурс] / режим доступу : http://lektsiopedia.org/lek-6894.html - загл. 3 екрану.

2 Особливості територіальної організації залізничного транспорту [Електронний pecypc] / режим доступу : http://xreferat.ru/113/11853-1-osoblivost-ter-tor-al-no-organ-zac-zalznichnogo-transportu.html - загл. $з$ екрану.

3 Договір перевезення вантажів на залізничному транспорті [Електронний ресурс] / режим доступу : http://ua-referat.com - загл. з екрану.

4 Кручинин, А.В. Оценка неравномерности завершения накопления составов в сортировочном парке [Тескт] / А. В. Кручинин, А. В. Никитин //Вестник ВНИИЖТ.- 1999. №5. - C. 11-12. 
Малахова Олена Анатоліївна, к.т.н., доцент кафедри управління експлуатаційної роботи Украӥнської державної академії залізничного транспорту Тел. (057)730-10-89 e-mail: alena_mal@mail.ru

Knyazeva Myroslava Ihorivna, Listener IPPK Tel. (066) 464-45-37 e-mail: knyazeva_miroslava@mail.ru

Malakhova Olena Anatoliivna, PhD. Of tehn. Sciences, Associate Professor of Management of operational work of the Ukrainian State Academy of Railway Transport Tel.(057)730-10-89 e-mail: alena_mal@mail.ru

УДК 656.212

\title{
ОПТИМІЗАЦІЯ РОБОТИ 3 ПОРОЖНІМИ ВАГОНАМИ НА ЗАЛІЗНИЦІ ІЗ ЗАСТОСУВАННЯМ ТЕОРІЇ УПРАВЛІННЯ ЗАПАСАМИ
}

\author{
К-т техн. наук П.В. Долгополов, магістрант О.С. Колмаков
}

\section{ОПТИМИЗАЦИЯ РАБОТЫ С ПОРОЖНИМИ ВАГОНАМИ \\ НА ЖЕЛЕЗНОЙ ДОРОГЕ С ПРИМЕНЕНИЕМ \\ ТЕОРИИ УПРАВЛЕНИЯ ЗАПАСАМИ}

\section{К-т техн. наук П.В. Долгополов, магистрант А.С. Колмаков \\ OPTIMIZATION OF EMPTY WAGONS WORK ON THE RAILWAY WITH USING INVENTORY MANAGEMENT THEORY}

\section{Cand. of tech. science P.V. Dolgopolov, master student A.S. Kolmakov}

Розроблено заходи з оптимізації оперативного резервування порожніх вагонів на вантажних та сортувальних станціях на основі математичного апарату теорії управління запасами. Застосування розробленої моделі дозволить в оперативному режсимі формувати оптимальний резерв вагонів в умовах обмеженості справного рухомого складу $і$ скоротити витрати від зривів доставки вантажу клієнтам залізниці.

Ключові слова: Оперативний резерв, порожні вагони, вантажна станція, теорія управління запасами, резерв вагонів, інтелектуальні системи оперативного управління, система з фіксованим інтервалом часу між замовленнями.

Разработаны меры по оптимизации оперативного резервирования порожних вагонов на грузовых и сортировочных станциях на основе математического аппарата теории управления запасами. Применение разработанной модели позволит в оперативном режиме формировать оптимальний резерв вагонов в условиях ограниченности исправного подвижного состава и сократить расходы от срывов доставки груза клиентам.

Ключевые слова: Оперативный резерв, порожние вагоны, грузовая станция, теория управления запасами, резерв вагонов, интеллектуальные системы оперативного управления, система с фиксированным интервалом времени между заказами.

At the article are proposed the measures designed to optimize the operative reserves of empty wagons on freight stations and marshalling yards on the basis of mathematical apparatus of the the theory of inventory management The application of the developed model will allow on-line to form the optimum reserve of wagons under conditions shortage of serviceable rolling stock and reduce costs by disruption of freight delivery to clients.

Implementation of the proposed technology is advantageously carried out on the basis of intelligent online control systems. On the example of the one freight station determined that it is advantageous to maintain a reserve of wagons according to system of inventory management with fixed time interval between orders. 
Keywords: The operative reserves, empty wagons, freight station, theory of inventory management, reserve of wagons, intelligent online control systems, system with fixed time interval between orders.

Вступ і актуальність теми. В умовах посилення конкуренції на ринку транспортних послуг для залізничного транспорту, операторських компаній та промислових підприємств однією з головних задач є стабільність процесу обслуговування вантажовласників [1,2,3]. Цьому сприяє створення резервів рухомого складу, що вимагає значних капіталовкладень.

Якщо керівництво будь-якого підприємства налаштоване оптимістично щодо перспектив економічного зростання, то приймається рішення зі збільшення обсягу інвестицій у створення резервів вагонного парку. Проте, 3 точки зору ресурсозбереження, такий підхід не $\epsilon$ зваженим - і особливо під час нестабільної економічної ситуації у країні, як зараз.

Виходячи 3 цього, на даний час актуальною постає задача оптимізації планування оперативного резерву порожніх вагонів на вантажних та сортувальних станціях на основі математичних методів. Реалізацію запропонованої технології доцільно проводити із застосуванням інтелектуальних систем оперативного управління.

Постановка задачі. Таким чином, метою даної наукової роботи $\epsilon$ розробка математичної моделі оптимізації резерву порожніх вагонів на станціях навантаження на основі математичного апарату теорії управління запасами. Застосування даної моделі дозволить в оперативному режимі формувати оптимальний резерв в умовах обмеженості справного рухомого складу i скоротити витрати від зривів доставки вантажу замовникам.

В логістиці товарно-матеріальні запаси вважаються фактором, що забезпечує безпеку системи матеріально-технічного постачання, іii гнучке функціонування, i постають в якості «страховки» $[3,4,5]$.

Визначення точної величини резерву вагонного парку на станціях, необхідного в умовах нестабільності термінів реалізації замовлень i мінливого попиту на вагони різного роду ускладнено ймовірнісною природою даних коливань. Це вказує на те, що для отримання задовільних рішень задач, пов'язаних 3 визначенням резерву вагонів, доцільно застосовувати математичні апарати імітаційного моделювання.

На основі аналізу існуючих математичних методів зроблено висновок про доцільність застосування при дослідженнях математичного апарату теорії управління запасами.

Основний зміст досліджень. Під час наукових досліджень проаналізовано існуючу систему регулювання парку порожніх вагонів та зроблено висновок, що в умовах домінування вагонного парку власності компаній-операторів $є$ необхідним подальший розвиток та застосування ймовірнісного планування резерву порожніх вагонів не на декаду, а на більш короткі терміни. При плануванні на декаду, майже завжди мають місце фактори, що не охоплені плануванням.

Згідно теорії управління запасами сформуємо основні стратегії та проаналізуємо можливість їх застосування відповідно мети безупинного забезпечення вантажовласника навантажувальними ресурсами:

- стратегія управління резервом вагонного парку з фіксованим розміром замовлення;

- стратегія 3 фіксованим інтервалом часу між замовленнями;

- стратегія зі встановленою періодичністю поповнення резерву до постійного рівня;

- стратегія «мінімум-максимум».

Система безупинного забезпечення потреби металургійного та енергетичного виробництва, яке домінує на базовому полігоні, повинна враховувати можливість появи різних відхилень у постачанні як з боку споживача резерву, так і з боку виконавця замовлення. Тому, для вирішення задачі оптимізації управління запасами необхідно побудувати модель стохастичного програмування [5,6]. 
У зазначених стратегіях керування резервами вагонів, незважаючи на орієнтацію ï на стабільні умови функціонування, передбачена можливість згладжування збоїв у постачаннях і споживанні. Так, стратегія 3 фіксованим розміром замовлення враховує один з восьми впливів, що збурюють (рис. 1), а саме затримку постачання. Цей вплив знімається введенням у систему параметра гарантійної величини резерву (ГВР), яка визначає рівень, при якому знову замовляються вагони. ГВР розраховується таким чином, що надходження замовлення відбувається в момент зниження поточного резерву до гарантійного рівня.

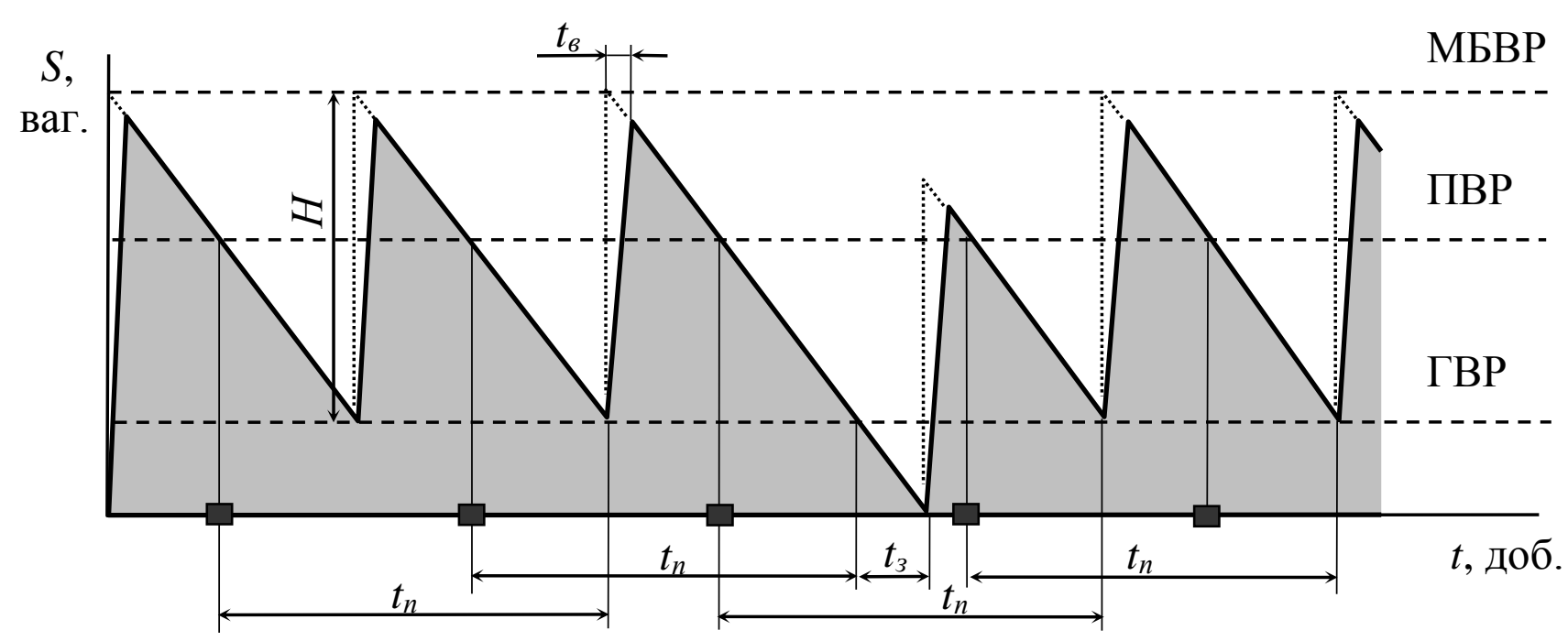

Рис. 1. Застосування стратегії управління порожніми вагонами з фіксованим розміром замовлення

Розмір замовлення вагонів строго зафіксований i не міняється в умовах роботи. Основною задачею стратегії $\epsilon$ визначення розміру замовлення.

Гарантійний (страховий) запас дозволяє забезпечувати потребу на час передбачуваної максимально можливої затримки постачання вагонів.

Максимальниа бажана величина резерву (МБВР) визначається для відстеження доцільного завантаження колій 3 погляду критерію мінімізації сукупних витрат.

Якщо можлива затримка постачання буде являти собою максимально можливу затримку, то механізм системи охоронить споживача від дефіциту у випадку одиничного збою в постачаннях. Другий розрахунковий параметр системи граничний рівень забезпечує підтримку системи в бездефіцитному стані. Період же часу, через який поповнюють гарантійний запасу до розрахункового обсягу, залежить від конкретних значень вихідних i фактичних параметрів системи.

Стратегія $з$ фіксованим інтервалом часу між замовленнями також враховує вплив затримки, що поставки, постачання (рис. 2). Оптимальний розмір замовлення при цьому дозволяє мінімізувати сукупні витрати на збереження резерву i повторення замовлення, а також досягти найкращого сполучення взаємодіючих факторів, таких, як використовувана довжина колій, витрати на збереження резервів i вартість замовлення.

ГВР дозволяє забезпечувати потребу на час передбачуваної затримки постачання. Заповнення гарантійного резерву виробляється в ході наступних постачань через перерахування розміру замовлення так, щоб його постачання збільшило резерв до максимального бажаного рівня [3].

Як i в системі 3 фіксованим розміром замовлення, цей вплив знімається параметром гарантійного запасу. Заповнення гарантійного запасу до розрахункового обсягу виробляється під час 
наступних постачань через перерахування розміру замовлення таким чином, щоб його постачання

збільшило резерв максимального бажаного рівня.

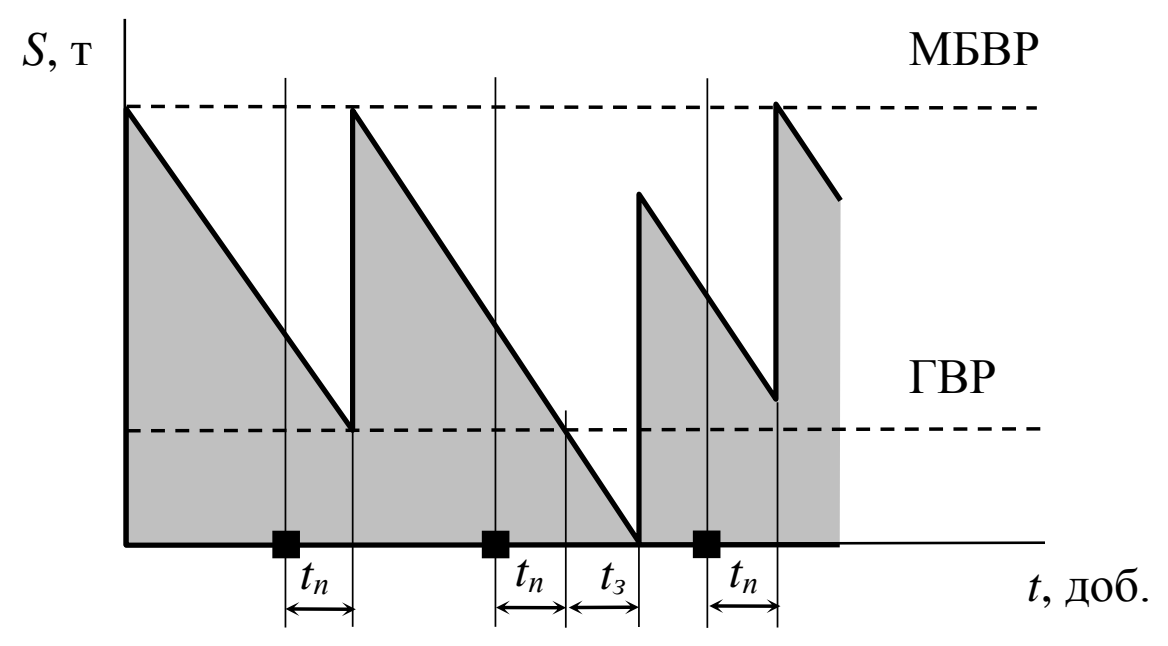

Рис. 2. Стратегія з фіксованим інтервалом часу між замовленнями вагонів

Стратегія 3 установленою періодичністю поповнення запасів до постійного рівня, на відміну від основних систем керування запасами, враховує можливість як затримки постачання, так i зміни темпів споживання від запланованих. Розширення здатності системи протистояти незапланованим впливам, що обурюють, зв'язано з об'єднанням ідей використання граничного рівня і фіксованого інтервалу між замовленнями. Відстеження граничного рівня підвищує чутливість системи до можливих коливань інтенсивності споживання.

Стратегія «мінімум-максимум» орієнтована на ситуацію, коли витрати на облік резервів на коліях і витрати на оформлення замовлення настільки значні, що стають порівнянні з утратами від дефіциту резервів. Це єдина 3 розглянутих раніше систем, що допускає дефіцит резервів по економічних розуміннях. Проте i система «мінімуммаксимум» враховує можливість затримки постачання через параметр гарантійного запасу.

Порівняння розглянутих стратегій управління резервом управління резервами приводить до виводу про наявність у них взаємних недоліків i переваг. Так, стратегія 3 фіксованим розміром замовлення вимагає безупинного обліку поточного резерву на складі. Навпроти, стратегія 3 фіксованим інтервалом часу між замовленнями вимагає лише періодичного контролю кількості резерву. Необхідність постійного обліку резерву в системі 3 фіксованим розміром замовлення можна розглядати як основний iii недолік. Відсутність постійного контролю за поточним резервом у системі 3 фіксованим інтервалом часу між замовленнями $\epsilon$ iï основною перевагою перед першою системою $[7,8]$.

У стратегії з фіксованим розміром замовлення МБВР завжди має менший розмір. Це приводить до економії на витратах по змісту резервів за рахунок скорочення колій, займаних резервами, що, у свою чергу, складає перевагу системи 3 фіксованим розміром замовлення перед стратегією з фіксованим інтервалом часу між замовленнями.

Оптимальний розмір партії $H_{\text {onm }}$ вагонів та їх завезення до вугільних шахт залежать від наступних факторів:

- обсяг оберту вагонів;

- транспортно-заготовчі витрати;

- витрати на простій резерву.

Досліджено, що при збільшенні розміру замовлення вагонів $H$ транспортно- 
підготовчі витрати зменшуються, оскільки перевезення здійснюється більш значними партіями, та, відповідно, рідше. Однак, витрати на зберігання вагонів $C_{x p}$ від $H$ мають прямо пропорційну залежність.

Задача визначення оптимального розміру замовлення може бути розв'язана графічним способом, причому, сумарні витрати на транспортування та зберігання становлять

$$
C=C_{m 3}+C_{x p} .
$$

Для розв'язання задачі визначення оптимального розміру замовлення аналітичним шляхом необхідно мінімізувати цільову функцію

$$
C=C_{x p}+C_{m 3} \rightarrow \min .
$$

Нехай за певний період $T$ часу оберт вагонів становить $Q_{T}$, а розмір однієї партії $H$.

Важливим елементом аналітичного розв'язання задачі $\epsilon$ розмір тарифу $c_{x p}$ за простій вагонів на коліях, що являє собою долю, яку складають витрати на зберігання за період $T$ у вартості середнього резерву за даний період.

Тоді, витрати на зберігання дорівнюють

$$
C_{x p}=\frac{c_{x p} \cdot H}{2}
$$

Розмір транспортно-приготовчих витрат становить $[5,6,9]$

$$
C_{m 3}=\frac{c_{m 3} \cdot Q_{T}}{H},
$$

де $c_{m з}$ - транспортно-заготовчі витрати, що пов'язано 3 розміщенням та доставкою одного заказу, грн.

Тоді, згідно (1-4), маємо

$$
\begin{aligned}
& C=\frac{c_{x p} \cdot H}{2}+\frac{c_{m 3} \cdot Q_{T}}{H} . \\
& H_{\text {onm }}=\sqrt{\frac{2 \cdot c_{m 3} \cdot Q_{T}}{c_{x p}}} .
\end{aligned}
$$

Перевірка показує, що $C^{\prime}>0$, тобто, отримане значення $H_{\text {onm }}$ забезпечує мінімум сумарних витрат на доставку та зберігання.
Значення та $c_{x p}$ здійснено на основі статистичних даних про транспортнозаготовчі витрати.

Кошторис витрат $c_{m з}$ включає наступні складові:

$x_{1}$ - витрати, що вов'язано 3 організацією замовлення, грн.;

$x_{2}$ - витрати на транспортування вантажу, грн.;

$x_{3}$ - інші витрати, що пов'язано 3 виконанням заказу, грн.

Тоді, враховуючи дані складові, маємо

$$
c_{m 3}=\frac{\sum_{i=1}^{n} x_{i}}{N_{3}},
$$

де $N_{3}$ - кількість заказів, що здійснено за період $T$.

Витрати $c_{x p}$ включають наступні складові:

$y_{1}$ - витрати на амортизацію колій, грн;

$y_{2}$ - витрати на можливий кредит для придбання резерву вагонів, грн;

$y_{3}$ - витрати на заробітну плату персоналу, пов'язаного технічним обслуговуванням резервів, грн.;

$y_{4}$ - адміністративні витрат, грн;

$y_{5}$ - витрати на охорону, втрати через пошкодження, грн. та інші $[6,10]$.

Отже,

$$
c_{x p}=\frac{2 \cdot \sum_{i=1}^{n} y_{i}}{H} .
$$

На основі моделювання та зібраних статистичних даних про місцеву роботу базової вантажної станції Д на рис. 3 отримано залежність $H=f\left(Q_{T}\right)$, за допомогою якої доцільно обрати оптимальний розмір замовлення порожніх вагонів в залежності від середньодобової величини навантаження.

Розрахунок параметрів систем управління запасами наведено у таблиці 1.

Величина резерву вагонів, яка повинна підтримуватися, на коліях в середньому за період спостережень при впровадженні системи з фіксованим розміром замовлення, становить 


$$
S_{c p}^{H}=\frac{H \cdot\left(t_{M \overline{0}-n}+t_{n}\right) \cdot\left(1-P_{3}\right)+\left(H-S_{2}\right) \cdot\left(t_{n}+t_{M \overline{0}-n}-t_{3}\right) \cdot P_{3}-t_{3} \cdot S_{2} \cdot P_{3}}{4}+S_{2}-\frac{t_{3} \cdot S_{2} \cdot P_{3}}{4} .
$$

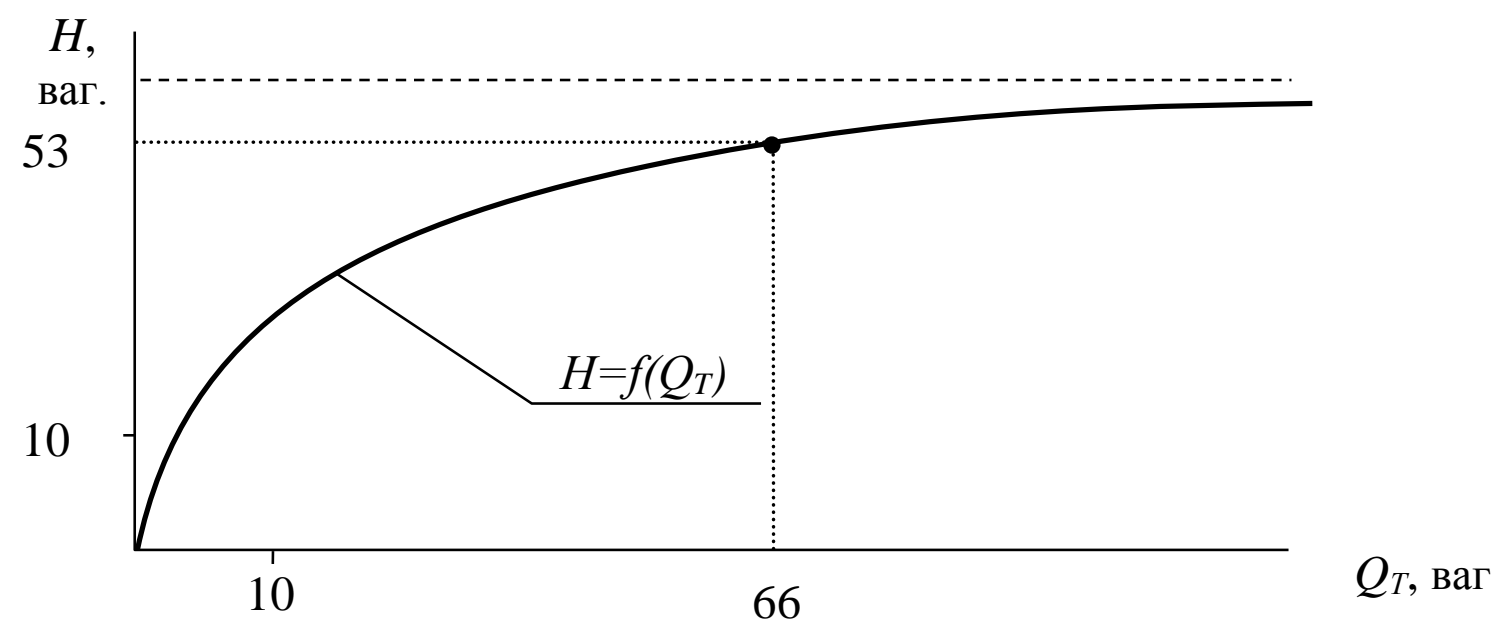

Рис. 3. Залежність оптимального розміру замовлення порожніх вагонів від їх обігу для базової вантажної станції Д

Таблиця 1

Визначення параметрів стратегій управління резервами вагонів

\begin{tabular}{|l|c|c|}
\hline \multicolumn{1}{|c|}{ Параметр } & \multicolumn{1}{|c|}{$\begin{array}{c}\text { Порядок } \\
\text { визначення }\end{array}$} & $\begin{array}{c}\text { Розрахунок } \\
\text { та результат }\end{array}$ \\
\hline Середньодобова потреба, ваг. & $Q_{T}$ & 66 \\
\hline $\begin{array}{l}\text { Оптимальний розмір замовлення, } \\
\text { ваг. }\end{array}$ & $H$ & 03 \\
\hline Тривалість поставки, доб. & $t_{n}$ & 0,81 \\
\hline Можлива затримка поставки, доб. & $t_{3}$ & $0,81 \cdot 66=54$ \\
\hline $\begin{array}{l}\text { Очікувана потреба за час поставки, } \\
\text { ваг. }\end{array}$ & $q_{n}=t_{n} \cdot Q_{T}$ & $66 \cdot(0,81+0,23)=69$ \\
\hline $\begin{array}{l}\text { Максимальна потреба за час } \\
\text { поставки, ваг. }\end{array}$ & $q_{n}{ }^{m a x}=Q_{T} \cdot\left(t_{n}+t_{3}\right)$ & $69-54=15$ \\
\hline ПВР, ваг. & $S_{n}=q_{n}{ }^{m a x}-q_{n}$ & $15+54-66=3$ \\
\hline \begin{tabular}{l} 
ГВР, ваг. \\
\hline МБВР, ваг.
\end{tabular} & $S_{2}=S_{n}+q_{n}-Q_{T}$ & $3+53=56$ \\
\hline Час вживання резерву до ПВР, доб. & $t_{m \sigma-n}=\left(S_{m \sigma}-S_{2}+H\right.$ & $(56-15) / 66=0,62$ \\
\hline $\begin{array}{l}\text { Час вживання резерву з ПВР до } \\
\text { ГВР, доб. }\end{array}$ & $t_{n-2}=\left(S_{n}-S_{2}\right) / Q_{T}$ & $(15-3) / 66=0,18$ \\
\hline
\end{tabular}

Величина резерву вагонів, яка повинна підтримуватися, на коліях в середньому за період спостережень при впровадженні системи 3 фіксованим інтервалом часу між замовленнями, становить 


$$
S_{c p}^{t}=\frac{H \cdot I \cdot\left(1-P_{3}\right)+\left(\left(H-S_{2}\right) \cdot\left(I-t_{3}\right)-S_{2} \cdot t_{3}\right) \cdot P_{3}}{4}+S_{2}-\frac{t_{3} \cdot S_{2} \cdot P_{3}}{4},
$$

де $I$ - інтервал часу між замовленнями, доб.

$$
\begin{gathered}
I=\frac{H}{Q_{T}} . \\
I=\frac{53}{66}=0,83 \text { доб. }
\end{gathered}
$$

Отже,

$$
S_{c p}^{t}=\frac{53 \cdot 0,8 \cdot(1-0,37)+((53-3) \cdot(0,8-0,23)-3 \cdot 0,23) \cdot 0,37}{4}+4-\frac{0,23 \cdot 4 \cdot 0,37}{4}=15 \text { ваг }
$$

Таким чином, результати досліджень свідчать, що при застосуванні системи 3 фіксованим інтервалом часу між замовленнями, розмір резерву скорочується на 6 вагонів, що складає 26\%. Тому, при організації процесу перевезень на залізничному полігоні резерв вагонів на базовій вантажній станції Д доцільно підтримувати згідно системи управління запасами 3 фіксованим інтервалом часу між замовленнями.

Висновки 3 дослідження i перспективи. У статті розроблено математичну модель визначення оптимального резерву вагонного парку. Її застосування дозволить в оперативному режимі визначати динамічні параметри резерву порожніх вагонів на станціях масового навантаження згідно найбільш раціональної стратегії. Це в свою чергу дозволить скоротити витрати на утримання резерву вагонного парку, а також витрати від штрафних санкцій через несвоєчасне подавання вагонів та доставку вантажу. Реалізацію запропонованої технології доцільно проводити із застосуванням інтелектуальних систем оперативного управління.

\section{Список використаних джерел}

1. Транспортна стратегія України на період до 2020 року. Схвалена розпорядженням Кабінету Міністрів України від 16 грудня 2009 р. №1555-р.: [Электрон.ресурс]. - Режим доступа: http://www.mintrans.gov.ua/uk/discussion/15621. html/ 10.12.2009.

2. Концепція державної програми реформування залізничного транспорту України [Текст] / Схвалено розпорядженням КМУ №651-р від 27.12.2006. - К.: Магістраль, №1 (1179) 10-16 січня 2007 р. - С. 6.

3. Інформаційні системи та технології при управлінні залізничними перевезеннями: навч. посіб. [Текст] / О.В. Лаврухін, П.В. Долгополов, В.В. Петрушов, О.М. Ходаківський. Х.: УкрДАЗТ, 2010.-122 с.

4. Ульяницкий Е.М., Филоненков А.И., Ломаш Д.А. Информационные системы взаимодействия видов транспорта [Текст]: учебное пособие для вузов ж.-д. транспорта / Е.М. Ульяницкий, А.И. Филоненков, Д.А. Ломаш - М.: Маршрут, 2005. - 264 с.

5. Гаджинский А.М. Логистика [Текст]: учебник / А.М. Гаджинский. - М.: Маркетинг, 1998. - 228c.

6. Смехов А.А. Основы транспортной логистики [Текст]: учебник / А.А. Смехов. - М.: Транспорт, 1995. - 197c.

7. Долгополов, П.В. Удосконалення технології регулювання порожніх вагонів та планування їх резерву на залізничному полігоні [Текст] / П.В. Долгополов, О.Г. Бужор, О.В. Волков, В.В. Шаповалов // Зб. наукових праць /УкрДАЗТ: Харків, 2013. - Вип. 135. - С. 4550 . 
8. Долгополов, П.В. Удосконалення експлуатації порожніх вагонів державних операторських компаній на основі логістичних принципів [Текст] / П.В. Долгополов, М.С. Водолажська, I.О. Єфімцева // Зб. наукових праць /УкрДАЗТ: Харків, 2012. - Вип. 133. - С. 30-35.

9. Системы автоматизации и информационные технологи управления перевозками на железных дорогах [Текст]: Учебник для вузов ж.-д. транспорта / В.А. Гапанович, А.А. Грачев [и др.]; под ред. В.И. Ковалева, А.Т. Осьминина, Г.М. Грошева. - М.: Маршрут, 2006. -544 с.

10. Управление експлуатационной работой и качеством перевозок на железнодорожном транспорте [Текст] : учебник для вузов / П.С. Грунтов, Ю.В. Дьяков, А.М. Макарочкин [и др.] ; под ред. П.С. Грунтова - М.: Транспорт, 1994. - 543c.

Рецензент д-р техн. наук, професор О.В.Лаврухін

Долгополов Петро Віталійович, к.т.н., доцент, Украӥнська державна академія залізничного транспорту, кафедра управління експлуатаиійною роботою 095-090-37-47 pit2013@таil.ru

Колмаков Олександр Сергійович, черговий по станиії, Донецькка залізниия, 050-777-82-02 , w_e_a_p_o_n@mail.ru

Dolgopolov Peter, PhD, docent, Office of management of operational work, Ukrainian Sate Academy of Railway Transport 095-090-37-47 pit2013@mail.ru

Kolmakov Alexander, station train manager, Donetskaya railway, 050-777-82-02,w_e_a_p_o_n@mail.ru

УДК 656.025.4:681.3

\section{ВАНТАЖНІ ПЕРЕВЕЗЕННЯ В МІЖНАРОДНОМУ СПОЛУЧЕННІ ПРИ ЗАСТОСУВАННІ ЗАСОБІВ ІНФОРМАТИЗАЦІЇ}

К-т техн. наук Д.В. Шумик, магістранти Д.О. Редіна, Т.М. Лавріненко

ГРУЗОВЫЕ ПЕРЕВОЗКИ В МЕЖДУНАРОДНОМ

СООБЩЕНИИ ПРИ ИСПОЛЬЗОВАНИИ СРЕДСТВ ИНФОРМАТИЗАЦИИ

К-т техн. наук Д.В. Шумик, магистранты Д.О. Редина , Т.М.Лавриненко

\section{INTERNATIONAL FREIGHT TRANSPORTATION UNDER INFORMATION SYSTEM DEVELOPMENT}

Cand. of techn. sciences. D.V. Shumyk, master student D.O.Redina, T.M.Lavrinenko

В даній роботі були представлені особливості та можливості удосконалення експлуатаційної роботи залізничної станції в умовах інформатизації за допомогою автоматизованої системи "АСК ВП УЗ - С». Завдяки можливості інтегрування "АСК ВП

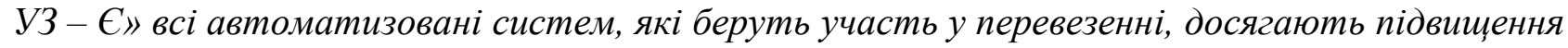
швидкості отримання, обробки, аналізу, відправки, та при необхідності корегування інформачії. Застосування «АСК ВП УЗ-С» забезпечить узгоджену роботу залізничних станцій, митних органів, та служб руху залізниці.

Ключові слова: інформатизація, удосконалення експлуатаційної роботи, оптимізація у реальному часі управлінських рішень, модернізачія, впровадження інформаційних систем.

В данной работе были представлены особенности $u$ возможности усовершенствования эксплуатаџионной работь железнодорожной станции в условиях информатизаџии с помощью автоматизированной системы «АСК ВП УЗ - Е». Благодаря возможности интегрирования $c$ помощью системь «AСК ВП УЗ - Е» всех 
автоматизированных систем, участвующих в перевозке, ускоряется процесс получения, обработки, анализа, отправки, и при необходимости корректировки информации. Применение «АСК ВП УЗ -Е» обеспечит согласованную работу железнодорожных станщий, таможенных органов, и служб движения железной дороги.

Ключевые слова: информатизаџия, усовершенствование эксплуатационной работы, оптимизачия в реальном времени управленческих решений, модернизация, внедрение информационных систем.

The research deals with peculiarities and possibilities to improve railway station operation under information system development with the United freight transportation control system of Ukrzaliznytsia (ACK ВП УЗ-E) which helps to integrate all automated systems involved in the transportation process, improve the process of receiving, processing, analyzing, transferring and, if required, correcting the information. The system shall provide coordinated operation of railway stations, customs bodies and railway transportation departments.

Keywords: information system development, improved operation, real-time optimization of managerial decisions, modernization, implementation of information systems.

Вступ. Вступ України до міжнародних транспортних організацій та структур, ратифікації міжнародних угод та конвенцій стали першим кроком на шляху інтеграції транспортно-дорожнього комплексу України до міжнародної транспортної системи. Цьому також сприяє географічне положення України на перехресті доріг з Європи до Азії, а також завантаженість європейських транспортних вузлів. Українські залізниці безпосередньо межують і взаємодіють із залізницями Росії, Білорусі, Молдови, Польщі, Румунії, Словаччини, Угорщини й забезпечують роботу із сорока міжнародними залізничними переходами, а також обслуговують 18 українських морських портів Чорноморсько-Азовського басейну. Дві третини українських залізничних ліній $\epsilon$ вантажонапруженими, сучасними засобами керування, диспетчерською централізацією й автоблокуванням.

Міжнародні перевезення зростають швидше, ніж внутрішні, оскільки транзитні маршрути стають більш протяжними i перетинають все більше кордонів, але все ж таки діюча система перевезень в умовах перебудови економіки вимагають принципових змін 3 метою забезпечення високої швидкості руху поїздів і скорочення часу доставки вантажів і пасажирів[1].

Постановка наукової проблеми. Транспортні комунікації та світова інформаційна мережа $\epsilon$ «кровоносними судинами» світового господарства. Інформаційні технології сьогодні - це не просто засіб підтримки управління, а один із основних елементів інфраструктури залізничного транспорту[2].

Поряд 3 розвитком інфраструктури важливе значення має розширення інформаційного забезпечення усього транспортно-технологічного комплексу для задоволення жорстким вимогам по строкам доставки, збереженню вантажів і безпеки транспортування, удосконаленню та спрощенню прикордонних i митних процедур.

Загальною метою, що досягається у результаті рішення даної задачі, повинно бути прискорення обробки поїздів та підвищення пропускної спроможності станцій за рахунок зменшення часу на комерційний i технічний огляд поїздів, a також на операції, що проводяться органами державного контролю (митним, прикордонним і ін.). Регламент їх виконання в значній мірі залежать від розвитку технологій та засобів електронного обміну даними, що забезпечують інформаційне супроводження перевезень вантажів в міжнародному сполученні. Система електронного обміну даними повинна відповідати міжнародній транспортній інфраструктурі, базуватися на узгоджених технічних параметрах i задовольняти потреби сумісності технологій перевезень як критерій інтеграції національної транспортної системи в світову систему[3]. 
Мета статті. Дослідити особливості та можливості удосконалення експлуатаційної роботи залізничних станцій в умовах інформатизації, що дозволить зменшити час обробки та простою транзитних вагонів на станціях, в масштабах залізниці збільшити навантаження та вагонопотік між державами, відкрити нові коридори, що забезпечить підвищення рівня попиту на залізничні перевезення та ефективну роботу залізничного транспорту в міжнародному сполученні.

Основна частина. Причини, що викликають затримку вантажів:

a) завантаженість митних органів та затримка, що виникає у зв'язку з цим, в транзитному оформленні вантажів;

б) завантаженість станції через велике накопичення вантажу;

в) відсутність залізничного рухомого складу;

г) відсутність чи некомплектність вантажосупровідних документів, чи наявність документів, що не відповідають вимогам законодавства, невірно оформлені документи;

д) незлагодженість між вантажовласником, генеральним

експедитором, залізницею, що впливає на документообіг;

е) незлагодженість в роботі між прикордонною передаючою та приймаючою стороною[4].

Для моделювання процесу формування маршрутних поїздів розглянемо загальний випадок, коли між джерелом постачання вагонів (митні органи та ін ) розміщуються технологічні операції. Для кожної станції, після визначення строків постачання вагонів та вантажів, формується задача організації маршрутного поїзда 3 обліком часу та технологічних схем митного огляду, роботи в регіоні прикордонних та сортувальних станцій. У загальному виді час знаходження вагонів та вантажів на станції до закінчення формування маршрутного поїзда визначається на основі збору статистичного матеріалу та його обробки математичними методами.

В загальному ланцюгу операцій по обробці поїзда на виконання операцій по комерційному, технічному, прикордонномитних операцій витрачається близько $30 \%$ часу.

Облік вагоно-годин у транспортнологістичній системі для вагонів, визначено за формулою:

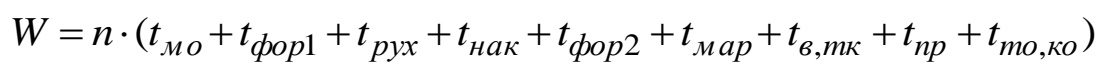

де $\mathrm{n}$ - кількість вагонів, що поступають на станцію для митного огляду;

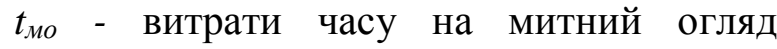
составів (операції проводяться паралельно 3 ТО та КО), 90 хв.;

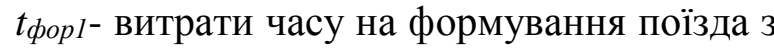
обліком простою під накопиченням на станції;

$t_{p y x}$ - час руху від прикордонної станції до станції формування транзитного поїзда;

$t_{\text {нак }}$ - витрати часу на накопичення вагонів на станції ;

$t_{\phi о р 2}$ - витрати часу на формування та очікування нитки графіку;

$t_{\text {мар }}$ - витрати часу на формування та транспортування до станції розформування маршруту;

$t_{\theta, m \kappa}$ - витрати часу на виконання операцій обробки перевізних документів в товарній конторі; $t_{n p}$ - час на операції по прийманню, 5 хв.;

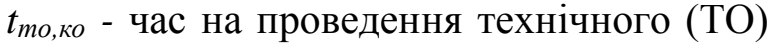
та комерційного огляду (КО) составу,45 хв. $[5,6]$.

Найсучаснішою

розробкою українських вчених залишається програма АСК ВП УЗ - $С$ (автоматизована система керування вантажними перевезеннями УЗ єдина). Основними перевагами цієї системи $€$ : оперативність надходження інформації, яка веде за собою значну економію часу на переробку та аналіз документації, надійність безперебійного забезпечення даними, можливість не тільки приймати та передавати інформацію, а й аналізувати, осмислювати, узагальнювати ii та автоматично формувати довідки та інші переваги. На автоматизованих робочих місцях станційних працівників передбачено підготовку й передачу інформації до бази 
даних «АСК ВП УЗ-С» про всі технологічні операції 3 поїздами, вагонами, контейнерами, локомотивами, а також про роботу окремих ділянок та підрозділів станції. «АCK ВП УЗдотримання логічної послідовності технологічних операцій міжнародних вантажних перевезень. Для досягнення цих задач доцільно організувати удосконалення впровадженої підсистеми АРМ логіста. Важливим засобом підвищення ефективності роботи залізничної станції $є$ застосування методів на базі інформаційно-керуючих систем (ІКС) i технологій. Переваги від застосування ІІКС $є$ : - оптимізація у реальному часі управлінських рішень 3 організації технологічних процесів спрямованих на мінімізацію витрат; збільшення доходів за рахунок використання маркетингових досліджень; - підвищення рівня рентабельності та максимізація прибутку. Стратегія реалізується при наявності таких функцій: - формування необхідної інформації для «АСК ВП УЗ-С»; оперативний контроль та аналіз процесу обробки експортно-імпортного вагонопотоку на прикордонній вантажній станції; економічна оцінка варіантів оперативних планів організації роботи станцій (за допомогою системи підтримки прийняття рішень); - контроль просування транспортного потоку за допомогою датчиків на вагонах із дотриманням технологічних норм на виконання операцій; прогнозування змін в оперативній ситуації на станції; - контроль за обсягом передачі вагонів через кордон; - прийняття рішень щодо керуючого впливу на перевізний процес на прикордонній вантажній станції; контроль за виконанням вантажних операцій як на під’їних коліях, а також формуванням оптимальних партій вантажів та вагонів у АРМ логіста. При формуванні IКС АРМ логіста 3 впровадженням GPS-моніторингу центральною частиною залишається вирішення задач планування, прогнозу й аналізу експлуатаційної роботи залізничної станції. До ІКС залізничної станції входить значна кількість АРМів. Кожне АРМ має доступ до потрібної інформації про стан перевізного процесу відповідно до статусу користувача та обсягу роботи, яку він виконує. При формуванні удосконаленої структури IКС потрібно врахувати зв'язки між АРМ працівників станції та автоматизованими системами різних рівнів та обмін інформацією між ними. Провадження лінії інформаційного обміну між АРМ логіста i «АСК ВП УЗ-С» дозволить працівнику контролювати переміщення вагонів, 3 можливими затримками i порушеннями, отримувати інформацію щодо транзитних та імпортних вагонопотоків для попереднього оформлення митних декларацій. Таке впровадження сприятиме зменшенню простоїв вагонів на залізничних станціях. Ще одна система, на яку покладається цілий комплекс технологічних завдань від розрахунку раціонального режиму ведення поїзда до контролю використання палива, - це система AC «Навігація. Інформація. Управління» «НІУ». Однією 3 важливих складових, що забезпечує вирішення комплексу технологічних завдань, $\epsilon$ можливість системи безперервно визначати координатне місцезнаходження одиниці рухомого складу, на яку встановлено відповідний датчик. Тим самим надається об'єктивна картинка дислокації рухомої одиниці. Системою «АСК ВП УЗ - С» дислокація поїзда, як сума декількох одиниць рухомого складу, визначається дислокацією локомотива (його номерами) у складі поїзда. Але ідентифікація складу одиниць (кількість та номери вагонів) у поїзді визначається оператором i формується за регламентом ручного уведення їх номерів у систему «АСК ВП УЗЄ» [7].

Висновки з дослідження i
перспективи, подальший розвиток у
даному напрямку. При використанні даних
системи залізниця отримує для себе низку
переваг таких як зниження експлуатаційних
витрат на перевезення за рахунок:-
зменшення трудових затрат на підготовку,
передачу, обробку перевізних документів
при міжнародних перевезеннях вантажів ,
разом з транзитними перевезеннями;-
зниження затрат на передавання даних про
місцезнаходження, підході, стан вантажу;--
зменшення втрати часу, що пов'язані 3


очікуванням обробки перевізних документів та виконання митних процедур при перетинанні межі в пунктах пропуску;покращення використання транспортних засобів та транспортного обладнання (приклад: зменшення випадків повернення через недостовірну інформацію); зменшення випадків втрати вантажів, роз'єднання вантажів та документів на них[8].

Отримання додаткового прибутку за рахунок: - розширення транспортних послуг та застосування сучасних транспортних технологій

та інформаційного забезпечення; - організація додаткових інформаційних послуг власникам вантажів, експортерам та імпортерам по спостеріганню за процесом перевезення.

Мінімізація втрат від відпущеного прибутку шляхом інформаційної взаємодії 3 партнерами та іншими учасниками перевезення вантажів в міжнародному повідомленні на основі застосування даних програм, підвищення оперативності реагування на зміни ситуації та кон'юнктури[9].

\section{Список використаних джерел}

1. О.А. Чуйко Розвиток міжнародних перевезень на українських залізницях [Текст] / О.А. Чуйко // : зб. наук. пр. / Укр. держ. акад. залізнич. трансп. - Х., 2010. - Вип. 119. - С. 20-22.

2. Зябиров Х.Ш «Развитие электронного документооборота при перевозках грузов в международном сообщении». [Текст] / Зябиров Х.Ш // Железнодорожній транспорт 2005 №7 - C. $12-14$.

3. Елисеев С.Ю. Логистические технологии в управлении грузовыми перевозками через пограничные переходы [Текст] / Елисеев С.Ю..// Ж.-Д. транспорт. № 7. 2006.- С 40-43

4. Орлова В.Г. Перевозка грузов в международном железнодорожном сообщении. [Текст]/ Орлова В.Г.// Под. ред.: Транспорт, 1983. 163 с.

5. Сычев А.Е Підвищення ефективності перевезень вантажів в міжнародному сполученні на основі принципів логістики [Текст]: автореф. дис. д-ра екон. наук : 25.04.2007 / Сичев А. Е. .-М ., 2007 .-30 с.

6. Елисеев С.Ю., К технологии логистических центров [Текст]: підруч. / Елисеев С.Ю., Котляренко А.Ф., Куренков П.В.. // Логистика. № 3. 2003. С. 5364.

7. Д.С. Кравченко Удосконалення вантажних перевезень у міжнародному сполученні на основі автоматизації оперативного управління [Текст]: / Д.С. Кравченко // : зб. наук. пр. / Укр. держ. акад. залізнич. трансп. . - Х., 2014 №146.- С 86-90

8. Галабурда В.Г. Оптимальное планирование грузопотока. [Текст]/ Галабурда В.Г. .// Под. ред.: М.: Транспорт, 1985.256 с.

9.Дерибас А.Т. Организация грузовой и коммерческой работы на железнодорожном транспорте. [Текст] : навч. посіб. / Дерибас А.Т., Повороженко В.В., Потапов В.П. ;М.: Транспорт. 1970. 311с.

Рецензент д-р техн. наук, професор О.М.Огар

Редина Дина Александровна, магістр $а н т$ E-mail :redinadina@yandex.ru

Лавріненко Тетяна Михайловна,магістрант E-mail :tasyayo@email.ua

Redina Dina Aleksandrovna , Master's Student E-mail :redinadina@yandex.ru

Lavrinenko Tatyana Mikhailovna, Master's Student E-mail :tasyayo@email.ua 
УДК 656. 212.5

ВИЗНАЧЕННЯ СТУПЕНЮ ЗАПОВНЕННЯ КОЛІЇ НАКОПИЧЕННЯ ВАГОНІВ 3 УРАХУВАННЯМ ЙМОВІРНОСНОГО ХАРАКТЕРУ УМОВ ЗОВНІШНЬОГО СЕРЕДОВИЩА

\author{
К-ти техн. наук М. Ю. Куценко, О. В. Розсоха, інженери О. А. Шабатіна, С. 3. Вітола \\ ОПРЕДЕЛЕНИЕ СТЕПЕНИ ЗАПОЛНЕНИЯ ПУТИ НАКОПЛЕНИЯ ВАГОНОВ С \\ УЧЕТОМ ВЕРОЯТНОСТНОГО ХАРАКТЕРА УСЛОВИЙ ВНЕШНЕЙ СРЕДЫ
}

К-ты техн. наук М. Ю. Куценко, О. В. Розсоха, инженеры Е. А. Шабатина, С. 3. Витола

DETERMINATION OF THE DEGREE OF FILLING THE PATH OF ACCUMULATION CARS IN VIEW OF THE PROBABILISTIC NATURE OF ENVIRONMENTAL CONDITIONS

Cand. of techn. sciences D. M. Kutsenko, D. O. Rozsoha, engineer E. Shabatina, S. Vitola

На даний момент проблема забезпечення якісного заповнення сортувальних колій остаточно не вирішена. Значна кількість відчепів не докочується до вагонів, що стоять на коліях, утворюючи «вікна». В чей же час відзначається досить велика кількість випадків співудару з неприпустимо високими швидкостями.

За відомою методикою для станиії Харків-Сортувальний була проведена статистична очінка ступеня заповнення колій накопичення вагонів з урахуванням ймовірносного характеру умов навколишнього середовища. Дані результати дозволять кількісно оцінювати ефективність різних заходів, спрямованих на поліпшення заповнення сортувальних колій.

Ключові слова: сортувальна станція, сортувальна гірка, сортувальний процес, заповнення сортувальних колій.

На данный момент проблема обеспечения качественного заполнения сортировочных путей окончательно не решена. Значительное количество отиепов не докатывается до вагонов, стоящих на путях, образуя «окна». В это же время отмечается достаточно большое количество случаев соударения с недопустимо высокими скоростями.

По известной методике для станции Харьков-Сортировочный была проведена статистическая оценка степени заполнения путей накопления вагонов с учетом вероятностного характера условий окружающей среды. Данные результаты позволят количественно оценивать эффективность различных мероприятий, направленных на улучшение заполнения сортировочных путей.

Ключевые слова: сортировочная станичя, сортировочная горка, сортировочный прочесс, заполнение сортировочных путей.

Practical operating experience marshalling yards shows that at the moment the problem of providing high-quality filling the marshalling lines finally solved. A significant number of wagons do not reach up to the wagons, standing on the tracks, forming a ,window”. At the same time there is a sufficiently large number of cases of unacceptably high impact velocities, while most of the damage occurs and freight wagons.

According to known methods for the station Kharkov-Sorting was performed statistical assessment of ways to fill the accumulation of wagons based on the probabilistic nature of environmental conditions. It was established that the average number of jumping per one part, for this station is 0.20 to 0.28 . These results allow to quantify the effectiveness of various measures aimed at improving the filling of sorting ways. 
lines.

Keywords: marshalling yard, marshalling hump, sorting process, filling the marshalling

Вступ. У даний час відбувається реформування залізничного транспорту, метою якого є підвищення якості надаваних послуг при безпечній та ефективній організації виробничого процесу [1]. В освоєнні перевезень на залізничному транспорті вирішальну роль відіграють сортувальні станції, що забезпечують реалізацію найбільш складної частини системи організації вагонопотоків - їx переробку i формування технічних маршрутів. Від успішної роботи сортувальних станцій залежить стійкість перевізного процесу на цілих напрямках i полігонах мережі залізниць.

\section{Актуальність}

Практичний досвід

проблеми. експлуатації сортувальних гірок показує, що в даний час проблема забезпечення якісного заповнення сортувальних колій остаточно не вирішена [2-4]. Значна кількість відчепів не докочується до вагонів, що стоять на коліях, утворюючи «вікна»[5] . В цей же час відзначається досить велика кількість випадків співудару 3 неприпустимо високими швидкостями, при цьому найчастіше відбувається пошкодження вагонів і вантажів.

Серед можливих причин, що обумовлюють подібну ситуацію 3 заповненням підгіркових колій $\epsilon$ невідповідність реального поздовжнього профілю 3 проектним; недостатність гальмових засобів; помилки оператора при гальмуванні відчепів; збої в роботі системи гальмування, викликані як повною, так і частковою відмовою технічних засобів; похибки визначення характеристик відчепів у зв'язку 3 недостатньо адекватним урахуванням великої кількості випадкових чинників (у тому числі впливу вітрових умов), а також ряд інших причин, часом таких, які важко піддаються формалізації.

$$
\text { Для вирішення завдання }
$$

забезпечення якісного заповнення сортувальних колій необхідно мати точні дані про вплив на цей процес ряду факторів. Наявність таких даних дозволить розробляти проектно-технічні рішення, спрямовані на оптимізацію параметрів сортувальних гірок 3 метою, як поліпшення заповнення колій, так i забезпечення дотримання вимог Правил технічної експлуатації залізниць України про безпечні умови співудару вагонів.

Необхідно відзначити, що можливість проведення точної кількісної оцінки впливу на процес заповнення колій різних зовнішніх i внутрішніх факторів значно ускладнюється тим, що в реальних умовах роботи гірки важко, а ще частіше неможливо чітко визначити, якою мірою той чи інший фактор вплинув на якість заповнення сортувальних колій. Наявність тимчасового впливу цілого ряду взаємодіючих змінних величин, багато 3 яких носять випадковий характер, створює свого роду «шум», на тлі якого дослідити певний фактор практично неможливо. Відсутність достатнього обсягу достовірних даних про вплив різних факторів на процес заповнення колій накопичення вагонів перешкоджає розробці ефективних проектних, інженерно-технічних та організаційних заходів, спрямованих на кардинальне поліпшення ситуації із забезпеченням мінімального обсягу роботи по осаджування вагонів на коліях сортувального парку та збільшенням збереження вагонів і вантажів за рахунок безумовного дотримання вимог Правил технічної експлуатації залізниць України [1] про безпечні швидкості зіткнення вагонів. Така ситуація свідчить про актуальність обраного напрямку досліджень.

Основна частина. У роботі [6] розроблена методика статистичної оцінки ступеня заповнення колій накопичення вагонів 3 урахуванням ймовірносного характеру умов навколишнього середовища. Згідно 3 цією методикою, за даними метеорологічної служби, яка має статистичні дані щодо вітрових умов у місці розташування сортувального комплексу, необхідно визначити ймовірності появи у даній місцевості вітрів певної швидкості і напрямку. При цьому слід враховувати той факт, що при різній температурі повітря ймовірності появи різних вітрових умов 
неоднакові (наприклад, при низьких температурах зазвичай не спостерігається сильних вітрів). Враховуючи наявність кореляції між вітровими і температурними характеристиками, середньомісячну величину кількості осаджувань, що приходяться на один состав, можна визначити за формулою

$$
\bar{K}^{n}=\sum_{i} \sum_{j} \sum_{l} P_{i, j, l}^{(n)} K_{i, j, l},
$$

де $P_{i, j, l}^{(n)}$ - ймовірність появи у $n$-му місяці вітру напрямку $i$ і швидкості $j$ при температурі $l$;

$K_{i, j, l}-$ середня кількість осаджувань, що приходяться на один состав, при відповідних умовах зовнішнього середовища.

У якості значень $i, j, \quad l$ використовуються фіксовані варіанти напрямку, швидкості вітру та температури.

Слід відзначити, що отримання інформації щодо корельованих ймовірностей появи різних температурних $\mathrm{i}$ вітрових умов на завжди можливе. У цьому випадку розрахунок величини середньої кількості осаджувань, згідно 3 методикою викладеною у [6] може проводитися наступним чином.

За даними метеорлогічної служби або спеціальних довідників [64,65] визначається середньомісячна температура $n$-го місяця $t_{\text {зов }}^{(n)}$. Далі визначаються ймовірності появи у $n$-му місяці вітру $i$-го напрямку і $j$-ої швидкості $P_{i, j}^{(n)}$. Оскільки, внаслідок особливостей проведення та обробки результатів метеорологічних спостережень, напрямки вітру зазвичай фіксуються по румбам, а швидкості вітру об'єднуються у градації, то у якості параметра $i$ слід прийняти умовний номер румба (від першого до восьмого 3 урахуванням проміжних румбів), а у якості параметра $j$ - номер градації швидкості вітру (зазвичай таких градацій сім). Середня кількість осаджувань, що приходяться на один состав у цьому випадку можна розрахувати за формулою

$$
\bar{K}^{n}=\sum_{i} \sum_{j} P_{i, j}^{(n)} K_{i, j},
$$

де $P_{i, j}^{(n)}$ - ймовірність появи у $n$-му місяці вітру напрямку $i$ та швидкості $j$;

$K_{i, j}$ - середня кількість осаджувань, що приходяться на один состав, при вітрі $i$-го напрямку та $j$-й швидкості при температурі $t_{306}^{(n)}$.

Середньорічна величина кількості осаджувань, що приходяться на один состав, в обох випадках може визначатися за формулою

$$
\bar{K}_{p i \varphi}=\sum_{k=1}^{12} \bar{K}^{(k)} / 12 \text {. }
$$

Для визначення

значень середньомісячної та середньорічної кількості осаджувань згідно 3 методикою [6] були виконані подібні розрахунки для прийнятих умов моделювання. Розраховувалися середні значення кількості осаджувань, що приходяться на один состав, по всім місяцям $\left(\bar{K}^{(n)}, n=\overline{1,12}\right), \quad$ а також величина середньорічної кількості осаджувань $\bar{K}_{\text {річ }}$. Розрахунок проводився у табличній формі.

Температурні умови були представлені декількома групами у відповідності до середньомісячної температури того чи іншого місяця [64]. Результати зведені у таблицю 1.

Таблиця 1

Середньомісячна температура повітря для м. Харкова, ${ }^{\circ} \mathrm{C}$

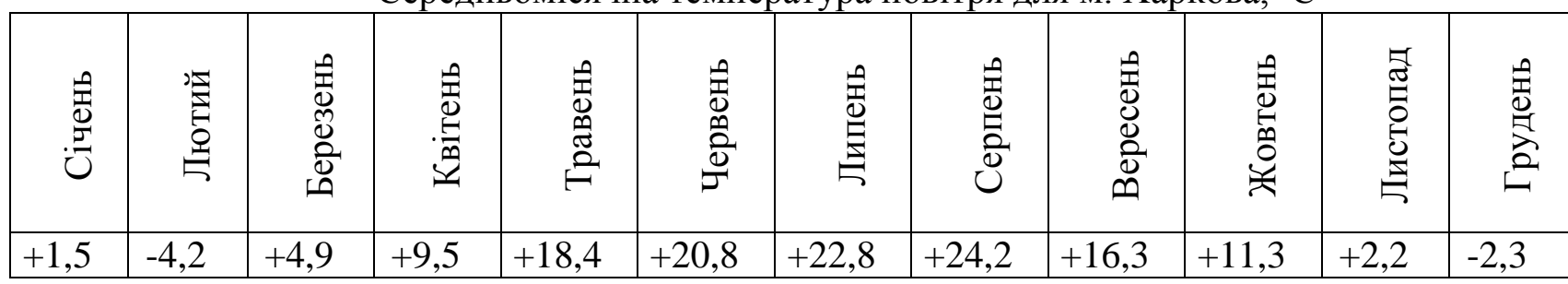


Для зменшення обсягів розрахунку місяці були об'єднані у декілька температурних груп. Так, у першу групу увійшли лютий та грудень $\left(t_{\text {зов }}^{(n)} \approx-3,3^{0} C\right)$, у другу - березень та листопад $\left(t_{\text {зов }}^{(n)} \approx+3,6^{0} C\right), \quad$ у третю - квітень та жовтень $\left(t_{\text {зов }}^{(n)} \approx+10,4^{0} C\right)$, у четверту травень та вересень $\left(t_{\text {зов }}^{(n)} \approx+17,4^{0} C\right)$, у п'яту - червень та серпень $\left(t_{\text {зов }}^{(n)} \approx+22,5^{0} C\right)$,
У шосту - липень $\left(t_{\text {зов }}^{(n)} \approx+22,8^{0} C\right)$ і в сьому - січень $\left(t_{\text {зов }}^{(n)} \approx+1,5^{0} C\right)$.

Приклад розрахунку $\bar{K}^{(7)}$ (для липня) наведений у таблицях 2-4. Дані щодо ймовірності появи того чи іншого вітру для липня [65] наведені у таблиці 2, розраховані у ході постановки імітаційних експериментів значення $\bar{K}_{i, j}$ зведені у таблиці 3. У таблиці 4 внесені розраховані значення $\left(P_{i, j}^{(n)} K_{i, j}\right)$.

Таблиця 2

Ймовірності появи вітру різної швидкості і напрямку для липня на станції Харків-

Сортувальний (у долях від одиниці)

\begin{tabular}{|c|c|c|c|c|c|c|c|c|}
\hline Швидкість & \multicolumn{7}{|c|}{ Напрямок вітру, $^{\text { }}$} \\
\cline { 2 - 9 } вітру м/с & 0 & 45 & 90 & 135 & 180 & 225 & 270 & 315 \\
\hline $0-1$ & 0,0640 & 0,0702 & 0,0550 & 0,0540 & 0,0430 & 0,0440 & 0,0420 & 0,0470 \\
\hline $2-5$ & 0,0700 & 0,0822 & 0,0470 & 0,0630 & 0,0500 & 0,0630 & 0,0690 & 0,0520 \\
\hline $6-9$ & 0,0110 & 0,0140 & 0,0020 & 0,0040 & 0,0140 & 0,0180 & 0,0080 & 0,0050 \\
\hline $10-13$ & 0,0010 & 0,0010 & 0,0000 & 0,0002 & 0,0020 & 0,0030 & 0,0002 & 0,0000 \\
\hline $14-17$ & 0,0000 & 0,0000 & 0,0000 & 0,0000 & 0,0004 & 0,0004 & 0,0002 & 0,0000 \\
\hline $18-20$ & 0,0000 & 0,0000 & 0,0002 & 0,0000 & 0,0000 & 0,0000 & 0,0000 & 0,0000 \\
\hline
\end{tabular}

Таблиця 3

Середня кількість осаджувань, що приходяться на один состав, при температурних умов липня (станція Харків-Сортувальний)

\begin{tabular}{|c|c|c|c|c|c|c|c|c|}
\hline Швидкість & \multicolumn{7}{|c|}{ Напрямок вітру, $^{\text {о }}$} \\
\cline { 2 - 9 } вітру м/с & 0 & 45 & 90 & 135 & 180 & 225 & 270 & 315 \\
\hline $0-1$ & 0,15 & 0,15 & 0,15 & 0,15 & 0,15 & 0,15 & 0,15 & 0,15 \\
\hline $2-5$ & 0,37 & 0,25 & 0,15 & 0,15 & 0,14 & 0,26 & 0,32 & 0,38 \\
\hline $6-9$ & 0,83 & 0,28 & 0,14 & 0,14 & 0,12 & 0,29 & 0,66 & 0,85 \\
\hline $10-13$ & 1,28 & 0,33 & 0,12 & 0,13 & 0,12 & 0,40 & 1,31 & 1,28 \\
\hline $14-17$ & 2,05 & 0,42 & 0,11 & 0,10 & 0,08 & 0,47 & 2,17 & 2,38 \\
\hline $18-20$ & 3,37 & 0,45 & 0,11 & 0,09 & 0,08 & 0,72 & 2,84 & 3,47 \\
\hline
\end{tabular}

Таблиця 4

Значення $P_{i, j}^{(n)} K_{i, j}$

\begin{tabular}{|c|c|c|c|c|c|c|c|c|}
\hline Швидкість & \multicolumn{9}{|c|}{ Напрямок вітру, $^{\text {о }}$} \\
\cline { 2 - 9 } вітру м/с & 0 & 45 & 90 & 135 & 180 & 225 & 270 & 315 \\
\hline $0-1$ & 0,0096 & 0,0105 & 0,0083 & 0,0081 & 0,0065 & 0,0066 & 0,0063 & 0,0071 \\
\hline $2-5$ & 0,0259 & 0,0206 & 0,0071 & 0,0095 & 0,0070 & 0,0164 & 0,0221 & 0,0198 \\
\hline $6-9$ & 0,0091 & 0,0039 & 0,0003 & 0,0006 & 0,0017 & 0,0052 & 0,0053 & 0,0043 \\
\hline $10-13$ & 0,0013 & 0,0003 & 0,0000 & 0,0000 & 0,0002 & 0,0012 & 0,0003 & 0,0000 \\
\hline $14-17$ & 0,0000 & 0,0000 & 0,0000 & 0,0000 & 0,0000 & 0,0002 & 0,0004 & 0,0000 \\
\hline $18-20$ & 0,0000 & 0,0000 & 0,0000 & 0,0000 & 0,0000 & 0,0000 & 0,0000 & 0,0000 \\
\hline
\end{tabular}

За результатами розрахунків состав. Для інших місяці у результаті величина $\bar{K}^{(7)}$ склала 0,23 осаджувань на аналогічних розрахунків були отримані 
наступні значення: $\bar{K}^{(1)}=0,21 ; \bar{K}^{(2)}=0,20$; $\bar{K}^{(3)}=0,23 ; \quad \bar{K}^{(4)}=0,26 ; \quad \bar{K}^{(5)}=0,28 ;$ $\bar{K}^{(6)}=0,25 ; \quad \bar{K}^{(8)}=0,23 ; \quad \bar{K}^{(9)}=0,23 ;$ $\bar{K}^{(10)}=0,24 ; \quad \bar{K}^{(11)}=0,24 ; \quad \bar{K}^{(12)}=0,21 ;$ $\bar{K}_{p i 4}=0,23$.
Висновок.

Запропонована [6] методика може використовуватися при визначення середньої кількості осаджувань за тривалий період часу (рік, місяць), для будь-яких місцевих умов роботи сортувальних комплексів.

\section{Список використаних джерел}

1. Правила технічної експлуатації залізниць України [Текст]: затверджені міністерством транспорту України N 411 від 20.12.1996. - К.: Мінтранс України, 1996. - 153 c.

2. Модин Н. К. Безопасность функционирования горочных устройств [Текст] / Н.К. Модин. - М.: Транспорт, 1994. - 153 с.

3. Тишков Л. Б. Теоретические и методологические основы корректировки алгоритмов расчета высоты, продольного профиля сортировочных горок и систем управления расформированием составов [Текст] / Л. Б. Тишков // Вестник ВНИИЖТа. М., 1996. - Вып. 6. - С. 22-26.

4. Тишков Л. Б., Рудановский В. М., Шейкин В. П. Повышение сохранности вагонов на сортировочных станциях [Текст] / Л. Б. Тишков, В. М. Рудановский, В.П.Шейкин // Железнодорожный транспорт. - М., 1983. - Вып. 12. - С. 7-13.

5. Медведева Н. Л. Совершенствование методов расчета горок малой мощности, обеспечивающих функционирование местных сортировочных систем [Текст]: автореф. дис. ... канд. техн. наук: 05.22.08 / Медведева Наталья Леонидовна. - М., 2001. - 26 с.

6. Карасёв С. В. Влияние конструкции горки, структуры вагонопотока и внешней среды на качество заполнения путей сортировочного парка [Текст]: дис. ... канд. техн. наук: 05.22.08 / Карасёв Сергей Владимирович. - Новосибирск, 2003. - 201 с.

7. Hansmann, R. S., Zimmermann, U. T. Optimal sorting of rolling stock at hump yards [Текст] / R. S. Hansmann, U. T. Zimmermann // Mathematics - key technology for the future. 2007. - № 8. - pp. 189-203.

8. Meuters, G. Modern car-retardants [Текст] / Meuters G. // Eisenbahningenieur. - 1997. №2. - P.17-22.

9. Gopner, M. Simulation of rolling unhook with hump [Текст] / Gopner M. // Rangiertechnik und Gleisanschlubtechnik. - 1987/1988. - P.25-29.

10. Siddiqee, M. W. Investigation of sorting and train formation schemes for a railroad hump yard [Текст] / M. W. Siddiqee // Proc. of the 5th Int. Symposium on the theory of trac flow and transportation. - 1972. - pp. 377-387.

11. Lower G.R. Modeme Prozessstenenmg fur Rangierbahnliofle [Текст] / G. R. Lower // Der Eisenbahningenieur. - 1982. - № 12. - pp. 527 - 531.

Рецензент д-р техн. наук, професор Є.С.Альошинський

Куценко Максим Юрійович канд. техн. наук, доцент кафедри залізничних станцій та вузлів Украйнська державна академія залізничного транспорту. Тел.: (057) 730-10-42 E-mail: maksimus84@meta.ua.

Розсоха Олександр Володимирович канд. техн. наук, доцент кафедри залізничних станиій та вузлів Украӥнська державна академія залізничного транспорту. Тел.: (057) 730-10-42 E-mail: s4749@yandex.ru.

Шабатіна Олена Анатоліїва студентка магістратури НН ІППК Українська державна академія залізничного транспорту Тел.: (057) 730-10-42.

Вітола Соломія Зіноӥвна студентка магістратури НН ІППК Украӥнська державна академія залізничного транспорту Тел.: (057) 730-10-42.

Shabatina Elena Anatoliyivna graduate student NN IPPK Ukrainian State Academy of Railway Transport Tel.: (057) 730-10-42. 
Rozsoha Alexander Volodymyrovych Ph. D., associate professor department of train stations and nodes Ukrainian State Academy of Railway Transport. Tel.: (057) 730-10-42 E-mail: s4749@yandex.ru .

Kutsenko Maxim Yriyovich Ph. D., associate professor department of train stations and nodes Ukrainian State Academy of Railway Transport. Tel.: (057) 730-10-42 E-mail: maksimus84@ meta.ua.

Vitola Solomiya Zinoyivna graduate student NN IPPK Ukrainian State Academy of Railway Transport Tel.: (057) 730-10-42.

УДК 330.341.1:334.02

\title{
МЕТОДИЧНІ ПІДХОДИ ДО СТРАТЕГІЧНОГО ПЛАНУВАННЯ ІННОВАЦЙНОӦ ДІЯЛЬНОСТІ ПІДПРИЕМСТВА
}

\author{
Д-р екон.наук О.Г.Дейнека, магістранти Д.В. Носенко, Д.О.Білецька
}

\section{МЕТОДИЧЕСКИЕ ПОДХОДЫ ПО СТРАТЕГИЧЕСКОМУ ПЛАНИРОВАНИЮ ИННОВАЦИОННОЙ ДЕЯТЕЛЬНОСТИ ПРЕДПРИЯТИЯ}

\section{Д-р экон.наук А.Г.Дейнека, магистранты Д.В. Носенко, Д.А.Белецкая \\ METHODICAL APPROACHES TO STRATEGIC PLANNING OF INNOVATIVE ACTIVITY OF ENTERPRISE}

\author{
Doct. of ekon. sciences O.H. Dejneka, master student D.V. Nosenko, \\ D.O. Biletska
}

Стаття присвячена вирішенню проблем пошуку можливостей удосконалення ефективності інновачійної діяльності підприємства та розробка пропозицій щуодо підвищення ефективності у иъій ланиі. Розкрито теоретичні та методичні підходи 3 удосконалення системи планування інноваційної діяльності на підприємстві залізничного транспорту. Проаналізовано тенденції сучасного розвитку підприємств залізничного транспорту, визначено роль інноващій на шляху активізаџії діяльності підприємства та розроблено пропозииії щодо удосконалення оцінки якості праці.

Ключові слова: залізничний транспорт, інноваџія, інноваџійна діяльність, інноваційна політика, об’єкт інноваційної діяльності, мета інноваційної політики.

Статья посвящена решению проблем поиска возможностей совершенствования эффективности инновачионной деятельности предприятия и разработка предложений по повышению эффективности в этом звене. Раскрыты теоретические и методические подходы по совершенствованию системы планирования инновачионной деятельности на предприятии железнодорожного транспорта. Проанализированы тенденции современного развития предприятий железнодорожного транспорта, определена роль инноваций на пути активизации деятельности предприятия $u$ разработаны предложения по совериенствованию оценки качества труда.

Ключевые слова: железнодорожный транспорт, инновация, инноваџионная деятельность, инновачионная политика, объект инновационной деятельности, цель инноващионной политики.

Article is devoted to solving problems finding opportunities to improve the efficiency of the enterprise innovation and development of proposals to improve the efficiency at this level. The theoretical and methodological approaches to improve the planning system innovation in the enterprise railway transportation. Analyzed the trends of modern development of railway transport, defined the role of innovation in the way of revitalizing the company and developed proposals to improve the assessment of the quality of work. Just analyze possible ways of attracting investments in the railway transport enterprise, and they brought the final assessment of investment climate in 
Ukraine. The article summarizes the most important aspects of evaluation of enterprise management, as well as its innovation, substantiated the importance of proper management of human resources predpriyatyai rail transport to improve iinovatsionnogo climate not only the company, but the industry as a whole. Role innovations disclosed in the broadest sense.

Keywords: railway transport, innovation, innovation, innovation policy, the object of innovation, the purpose of innovation policy.

\section{Вступ.}

Становище залізничного транспорту багато в чому визначається його здатністю адаптуватися до мінливих умов конкурентної боротьби, можливостями здійснювати активну інноваційну діяльність. Успішне функціонування залізничних підприємств, забезпечення їх високої конкурентоспроможності є можливим лише на базі передової технології, що в реальному часі можна досягти шляхом реалізації інноваційної стратегії. Успіх останньої визначається науково обгрунтованим підходом до інноваційного розвитку підприємства і галузі в цілому.

Розвиток залізничного транспорту тісно пов'язаний з розвитком інших галузей економіки. Разом 3 тим, залізничний транспорт, впливаючи на рівень життя i розвиток продуктивних сил, $\epsilon$ системоутворюючим фактором. Геополітичне положення України і країн пострадянського простору, мультимодальна специфіка високотехнологічного перевізного процесу створюють об'єктивні передумови реалізації ідеї формування єдиного транспортного простору. У цих умовах найбільшої актуальності для залізничного транспорту України набувають питання активізації інноваційної діяльності.

Постановка проблеми у загальному вигляді та іiі зв'язок із важливими науковими та практичними завданнями.

Світовий ринок транспортних послуг встановлюе нові вимоги до якості послуг, які надаються залізничним транспортом. Найбільш актуальними та затребуваними стають послуги, які відповідають критеріям швидкості, комплексності і безпечності.

В сучасних наукових дослідженнях змістовно обгрунтовано необхідність використання стратегічного підходу до планування інноваційної діяльності підприємства. Проте деякі важливі аспекти формування та розвитку методичних основ організації інноваційної діяльності в умовах структурно-інноваційних трансформацій економіки не дістали належного висвітлення. Розробка i впровадження інновації стає одним 3 основних напрямків стратегії підприємства та організації. Саме це визначає різноманітні напрямки їx розвитку.

\section{публікацій. \\ Аналіз останніх досліджень i}

В економічній літературі певна увага приділяється переважно загальним питанням 3 управління інноваційною діяльністю. Щодо планування інноваційної діяльності підприємств, зокрема залізничного транспорту доцільно зазначити недостатню вивченість. Ефективна система планування сприяє якнайшвидшому впровадженню досягнень науки і техніки, зростанню науково-технічного потенціалу підприємства та раціональному використанню наявних ресурсів. Тому дослідження системи планування інноваційної діяльності та обгрунтування напрямів іiі удосконалення 3 актуальною проблемою розвитку теорії та практики залучення інновацій.

Певний вагомий вплив щодо дослідження зазначеного напрямку мають праці та дослідження вчених та спеціалістів. Зокрема це публікації Ю.С. Бараша, І.В. Бєлова, А.В. Гриньова, Ю.Ф. Кулаєва, В.І. Пасічника, I.M. Писаревського, В.Г. Шинкаренка, Н.П. Тертишної, М.Ф. Трихункова, І.В Бессонова, В.Г. Галабурди, В.Л. Диканя, В.П. Ільчука, Б.М. Лапідуса, Л.О. Позднякова, Є.М. Сича.

\section{Визначення мети та задачі} дослідження.

Кардинальні зміни, що мають місце в умовах реалізації концепції державної програми реформування залізничного транспорту, потребують додаткових досліджень 3 розробки процесів удосконалення інноваційної діяльності 
структурних підрозділів та відокремлених підприємств залізничного транспорту. Саме цей аспект і $є$ предметом дослідження, що покладено в основу публікації.

Метою передбачуваних досліджень $\epsilon$ пошук можливостей удосконалення ефективності інноваційної діяльності на залізничному транспорті та розробка пропозицій щодо підвищення ефективності інноваційної діяльності, які полягають в обгрунтуванні теоретичних та методичних підходів та практичних рекомендацій 3 удосконалення системи планування інноваційної діяльності на підприємстві залізничного транспорту:

- проаналізувати сучасні тенденції інноваційного розвитку підприємств залізничного транспорту України.

- оцінити спроможності до інноваційного розвитку підприємства;

- оцінити показників інноваційної діяльності;

- виявити перелік невикористаних резервів підвищення ефективності інноваційної діяльності;

- оцінити вплив інноваційних рішень на фінансові результати діяльності підприємства;

- розробити пропозиції щодо удосконалення методичного підходу до оцінки якості праці спеціалістів 3 точки зору можливості їх залучення до інноваційної діяльності.

- запропонувати систему управління інноваційними ідеями співробітників на підприємстві залізничного транспорту

\section{Основна частина дослідження.}

У світовій економічній літературі “інновація" інтерпретується як перетворення потенційного науково-технічного прогресу в реальний, що втілюється в нових продуктах i технологіях. Поняття “інновація" означає нововведення, тобто впровадження нових форм організації праці й управління на підприємствах залізничного транспорту; це використання в тій чи іншій сфері суспільної діяльності результатів інтелектуальної праці, технологічних розробок, спрямованих на удосконалення діяльності.

Розробка інновацій - один з основних напрямків стратегічного планування, i.1 метою $є$ визначення підходів до науковотехнічної діяльності організації 3 наступними складовими:

- розробка і впровадження інновації;

- розробка i впровадження нових технологічних процесів при освоєнні нової продукції;

- удосконалення технології, що використовується

Щодо інновацій то це будь-які технічні, організаційні, економічні й управлінські зміни, відмінні від існуючої практики на підприємстві. Вони можуть бути відомі і використовуватися в інших організаціях, але для тих організацій, у яких вони ще не освоєні, їхнє впровадження є новою справою і може привести до неочікуваних труднощів. Організації мають різну сприйнятливість до інновацій, їхній інноваційний потенціал істотно залежить від параметрів організаційних структур менеджменту, професійно-кваліфікаційного складу, промислово-виробничого персоналу, зовнішніх умов господарської діяльності й інших факторів.

Інновації знаходяться, з одного боку, у протиріччі 3 усім консервативним, спрямованим на збереження існуючого становища, 3 іншого боку, - націлені, у межах стратегії змін, на значне підвищення техніко-економічної ефективності діяльності організації.

Інновація - елементарна складова підприємництва, завжди властива ринковій економіці. Але вона $є$ так само поєднанням раціональності й ірраціональності. Творчість $\epsilon$ двигуном інновації, вона $\epsilon$ «первинним ресурсом» підприємництва в ринковій економіці. Проаналізувавши та узагальнивши означення різних авторів $\epsilon$ підстави стверджувати, що інновації - це суттєво вдосконалені або абсолютно нові продукти, технології або методи управління.

Під інноваційною діяльністю розуміється діяльність колективу, спрямована на забезпечення доведення науково-технічних ідей, винаходів (новацій) до результату, придатного до практичного застосування та реалізації їх на ринку з метою задоволення потреб суспільства в конкурентоспроможних товарах і послугах. 
Ця діяльність охоплює:

- випуск i поширення принципово нових видів техніки і технології;

- прогресивні міжгалузеві структурні зрушення;

- реалізацію довгострокових науковотехнічних програм 3 великими строками окупності витрат;

- фінансування фундаментальних досліджень для здійснення якісних змін у стані продуктивних сил;

- розробку і впровадження нової ресурсозберігаючої технології, призначеної для поліпшення соціального й екологічного становища .

Об'єктом інноваційної діяльності $\epsilon$ інновації (нововведення; лат. novo змінювати, оновлювати). Це новостворені i вдосконалені технології, продукція або послуги, а також організаційно-технічні рішення виробничого, адміністративного, комерційного або іншого характеру, що суттєво поліпшують структуру та якість виробництва і соціальної сфери.

Мету інноваційної діяльності можна звести до наступного:

- пошук нового технічного рішення створення винаходу;

- проведення наукових досліджень і технологічних розробок;

- технологічна підготовка серійного виробництва нової продукції;

- закріплення продукції на нових ринках шляхом постійного удосконалювання технології, конкурентоспроможності.

Інноваційна діяльність пов'язана 3 трансформацією наукових досліджень і розробок, винаходів і відкриттів у новий продукт або новий технологічний процес, які впроваджуються у виробничий процес, або в новий підхід до соціальних послуг. Інноваційна діяльність передбачає створення цілого комплексу наукових, технологічних, організаційних, фінансових i комерційних заходів, які у своїй сукупності ведуть до створення інновації «під ключ», тобто повністю готової до реалізації на ринку.

Серцевиною інноваційної діяльності на підприємстві є освоєння (комерціалізація) нових видів продукції або методів іiі виробництва, доставки і реалізації. Визначаючи напрями інноваційної діяльності, керівництво фірми вирішує, на чому зосереджувати увагу: на продуктових чи технологічних інноваціях. При цьому важливо, хто $є$ «ініціатором» інновації: споживач, постачальник чи конкурент.

Інноваційна діяльність у повному обсязі має комплексний, системний характер і охоплює такі види роботи, як пошук ідей, ліцензій, патентів, кадрів, організацію дослідницької роботи, інженерно-технічну діяльність, яка об'єднує винахідництво, раціоналізацію, конструювання, створення інженерно-технічних об'єктів, інформаційну та маркетингову діяльність. Усе це створює прогресивні умови для інноваційного розвитку та активізації інноваційних процесів. Тобто інноваційна діяльність розглядається як сукупність робіт, які виконуються певними організаційними структурами від зародження ідеї, іiі розроблення i до комерціалізації в умовах конкуренції.

Для успішного керування інноваційною діяльністю необхідно ретельне вивчення інновацій. Насамперед, необхідно вміти відрізняти інновації від несуттєвих видозмін у продуктах i технологічних процесах

Здійснення управління інноваційною діяльністю в цілому включає:

- розробку планів та програм інноваційної діяльності;

- нагляд за розробкою нової продукції та технології, її впровадження;

- розгляд програм розробки нової продукції та технології;

- забезпечення єдиної інноваційної політики та координації;

- забезпечення фінансовими та матеріальними ресурсами програм інноваційної діяльності;

- затвердження тимчасових цільових груп для комплексного вирішення інноваційних проблем - від ідеї до серійного виробництва продукції.

- Здійснення інноваційної політики в цілому допускає розробку планів і програм інноваційної діяльності; спостереження за ходом розробки інновації i іiі 
впровадженням; розгляд проектів розробки інновації, проведення єдиної інноваційної політики; координацію інноваційної діяльності у функціональних і виробничих підрозділах; забезпечення фінансовими i матеріально-технічними забезпечення розробки ресурсами; кваліфікованими кадрами; створення тимчасових цільових груп для комплексного вирішення інноваційних проблем - від мети до впровадження інновації.

- Інноваційна діяльність становить органічну частину маркетингової діяльності організації, особливо це відноситься до організацій, зайнятих виробництвом наукомісткої продукції. Тут спостерігається особливо тісна взаємодія інженернотехнічних підрозділів 3 підрозділом маркетингу.

- Інноваційний розвиток залізничного транспорту на сьогодні спрямований на досягнення параметрів економічної ефективності, екологічної та функціональної безпеки галузі. Для успішного проведення інноваційної діяльності підприємств залізничного транспорту необхідне приведення інноваційного процесу у відповідність до сучасних вимог.

- Отже, можна зробити висновок, що інноваційна діяльність на залізничному транспорті - це комплексний процес виробництва нових чи удосконалених наявних транспортних послуг на основі розробки, впровадження прогресивних техніко-економічних і управлінських рішень

- Головною перешкодою ефективного інноваційного розвитку підприємств залізничного транспорту $\epsilon$ те, що інноваційна діяльність зорієнтована тільки на потреби зовнішнього споживача, ігноруючи при цьому внутрішні потреби самого підприємства-новатора в інноваціях. Це є грубою помилкою, здатною призвести до значних втрат. Особливо актуальним i важливим стає питання щодо інноваційного розвитку такої технологічно і організаційно складної галузі, як залізниця.

- Для забезпечення ефективності інноваційної діяльності підприємств залізничного транспорту виняткового значення набуває спрямування інноваційної діяльності

підприємств

залізничного транспорту на потреби зовнішніх споживачів транспорту та на задоволення внутрішніх потреб підприємства в інноваціях.

- Інноваційна діяльність підприємств залізничного транспорту повинна відбуватись за тими напрямами, що формують їх розвиток. В першу чергу, це ті напрями, де спостерігається відставання нашого транспорту від транспорту закордонних країн, а саме: впровадження швидкісного та високошвидкісного руху, що $€$ характерним для розвитку транспортних систем багатьох країн сучасного світу. Актуальним напрямом інноваційної діяльності $€$ оновлення на новій технологічній основі загального парку вантажних i пасажирських вагонів, локомотивів і залізничної інфраструктури.

Основні труднощі ведення успішної інноваційної діяльності підприємств залізничного транспорту пов'язані з браком власних коштів, обмеженістю бюджетного i позабюджетного фінансування по всьому ланцюгу, що визначає результативність інноваційного циклу: освіта, наука, виробництво, реалізація i сервіс в споживанні. Рішення даної проблеми можливо тільки в поєднанні державного i підприємницького секторів, які дозволять ефективно використовувати стратегії, активізувати інноваційну активність i нарощувати об'єми виробництва конкурентоздатної наукової продукції.

3 допомогою техніко-економічного аналізу можна виявити протиріччя та визначити проблеми технологічного оновлення 3 метою прискорення процесу реалізації інноваційної моделі розвитку залізничного транспорту.

Інноваціями на залізничному транспорті є система проривних поліпшень у техніці та технологіях, спрямованих на відкриття нових можливостей для зростання ефективності залізниць.

Загальна концепція формування інноваційної політики на транспорті формується з таких позицій:

- створення умов сталого, безпечного i ефективного функціонування залізничного транспорту як організуючого елемента 
транспортної системи країни для реалізації основних геополітичних і геоекономічних цілей країни;

- інноваційна політика держави повинна заохочувати суб'єктів господарювання всіх форм власності до результативної інноваційної діяльності, залишаючи собі функції регулювання науково-технічного розвитку залізничного транспорту;

- підвищення ефективності роботи на основі впровадження новітніх методів i засобів управління, технологій i техніки перевізного процесу, створення принципово нових комплексних форм обслуговування клієнтів;

- рівень якості обслуговування, гнучке реагування на запити клієнтів, гнучка тарифна політика $\epsilon$ найважливішими показниками конкурентноспроможності того чи іншого виду транспорту, інструментом для завоювання ринку;

$$
\text { - застосування }
$$

ефективних

механізмів управління галуззю та іiі структурними підрозділами, які базуються на сучасних інформаційнотелекомунікаційних технологіях.

Мета комплексного аналізу інноваційної діяльності полягає в обгрунтуванні найбільш ефективних напрямів інноваційної діяльності, інноваційних програм i проектів фірми. Основними завданнями комплексного аналізу є:

- визначення

відповідності фінансового стану фірми його цільовим параметрам щодо інноваційного розвитку;

- оцінювання спроможності до інноваційного розвитку;

- вибір інноваційних проектів;

- оцінювання показників інноваційної діяльності;

- виявлення невикористаних резервів підвищення ефективності інноваційної діяльності;

- оцінювання впливу інноваційних рішень на фінансові результати діяльності фірми.

Для комплексного інноваційної діяльності фірми потрібно використовувати різноманітні джерела інформації: дані спеціальних обстежень, статистичні дані Державного комітету статистики України, звітні дані підприємства, регістри бухгалтерського обліку, первинну документацію підприємства.

Одним із найскладніших етапів оцінювання ефективності інновацій $\epsilon$ побудова системи моніторингу зовнішнього оточення фірми, тобто системи постійного спостереження за напрямами й досягненнями науково-технічного прогресу в конкретній та суміжній галузях.

В сучасних наукових дослідженнях змістовно обгрунтовано необхідність використання стратегічного підходу до планування інноваційної діяльності підприємства. Проте деякі важливі аспекти формування та розвитку методичної основи організації інноваційної діяльності в умовах структурно-інноваційних трансформацій економіки не дістали належного висвітлення, тому вимагають уточнення. Світовий ринок транспортних послуг встановлює нові вимоги до якості послуг, які надаються залізничним транспортом. Найбільш актуальними та затребуваними стають послуги, які відповідають критеріям швидкості, комплексності, безпечності та екологічності.

За часів планової економіки залізничний транспорт мав чітку структуру управління і займався тільки дозволеними видами перевезень. Збереження вказаної структури в ринкових умовах зумовило появу монопольного утворення для деяких видів вантажних і пасажирських перевезень. Об'єктивні причини гальмування розвитку економіки України призвели до спаду в кілька разів обсягів залізничних перевезень, що негативно позначилося на діяльності Укрзалізниці. Залізниці стали працювати не в оптимальному режимі й втратили частину прибутку від ефекту збільшення обсягів перевезень. До того ж уряд припинив фінансування розвитку залізничного транспорту, а державні організації не в повному обсязі сплачують компенсацію за перевезення пільгових категорій громадян. На тих частках ринку, де залізничний транспорт конкурує 3 реформованою 
структурою автомобільного транспорту, він практично «програє» в боротьбі за приміські пасажирські й дрібні вантажні перевезення. Предметом дослідження $є$ процеси удосконалення інноваційної діяльності підприємства.

Основні труднощі ведення успішної інноваційної діяльності на підприємстві пов'язані 3 браком власних коштів, що визначає результативність інноваційного циклу. Рішення даної проблеми можливо тільки в поєднанні державного i підприємницького секторів, які дозволять ефективно використовувати стратегії, активізувати інноваційну активність i нарощувати об'єми виробництва конкурентоздатної наукової продукції.

Висновки 3 дослідження
перспективи, подальший розвиток
даному напрямку.
На основі дослідження теоретичних
основ інноваційної діяльності було
отримано наступні результати:

\section{Список використаних джерел}

1 Дикань, В.Л. Забезпечення ефективності інноваційної діяльності підприємств залізничного транспорту : монографія [Текст]/ В.Л. Дикань, В.О. Зубенко. - Х. : УкрДазт, 2008.-194 c.

2 Інноваційно - інвестиційні системи залізничного транспорту: становлення та розвиток [Текст] / За ред. Сича Є.М.- К. : Логос, 2004. - 381с.

3 Сич, С.М. Інноваційно - інвестиційний розвиток залізничного транспорту [Текст] / Є.М. Сич , В.П. Ільчук - К.: Логос, 2002. - 256с.

4 Цвєтов Ю.М., Макаренко М.В., Цвєтов М.В. Проблеми та основні напрями реформування залізничного транспорту України [Текст]/ Ю.М. Цвєтов, М.В. Макаренко М.Ю. Цвєтков та ін. - К. : КУЕТ, 2007. - 222 с.

5 Закон України «Про інноваційну діяльність» [Текст] // Відомості Верховної Ради України. - 2002. - № 36.

6 Інноваційний розвиток промисловості України [Текст]/ O. I. Волков, М. П. Денисенко, А. П. Гречан та ін. / Під ред. О. І. Волкова, М. П. Денисенка. - К. : КНТ, 2006. -648 c.

7 Оцінка економічної доцільності інвестицій в інноваційні проекти на транспорті : навчальний посібник [Текст]/ Є. І. Балака, О. І. Зоріна, Н. М. Колесникова, I. М. Писаревський. - Харків : УкрДАЗТ, 2005. - 210 с.

Дейнека Олександр Георгійович, д.е.н.,професор,завідувач кафедри менеджменту $і$ адміністрування Української державної академії залізничного транспорту. Tел. (057) 730-10-46 E-mail: dejneka@list.ru

Носенко Дмитро Вололдимирович,магістрант Тел. (050)998 7411

Білецька Дар'я Олександрівна, магістрант ,Тел. (063)607-41-97

Dejneka Oleksandr Heorgiyovich, d.e.s., professor, head of department of management and administration Ukrainian State Academy of Railway Transport. Tel. (057) 730-10-46 E-mail: dejneka@list.ru

Biletska Daria Oleksandrivna, Tel. (063)607-41-97

Nosenko Dmitro Volodumurovich, Master's Student Tel.. (050)998 7411 
УДК 331.101.03: 65.01

\section{ОРГАНІЗАЦІЙНІ АСПЕКТИ СТВОРЕННЯ СИСТЕМИ МОТИВАЦІЇ НА ПІДПРИЕМСТВІ}

К-т екон. наук О.В.Громова, магістрант С.О. Носик

\section{ОРГАНИЗАЦИОННЫЕ АСПЕКТЫ СОЗДАНИЯ СИСТЕМЫ МОТИВАЦИИ НА ПРЕДПРИЯТИИ}

К-т.экон.наук Е.В.Громова, магистрант С.А.Носик

ORGANIZATIONAL ASPECTS OF CREATION OF MOTIVATION FOR THE ENTERPRISE

Cand. of econ. sciences E.V.Gromova, master student S.O.Nosik

Стаття присвячена вирішенню проблем пошуку моделі стимулювання мотивачії персоналу та удосконалення процесу праці на підприємстві. Доведена роль важливості вибору мотиваційної моделі поведінки. Були запропоновані деякі заходи, щуодо координації дій керівника, необхідні для найбільи ефективної мотивації прачівників $i$ забезпечення оптимального рівня якості виконання ними роботи, при обліку необхідності задоволення їхніх потреб.

Ключові слова: мотивачуі, персонал, мотиваційні теорії, фактори мотивації, трудова мотивачія, модель поведінки.

The article is devoted to solving problems of finding models to stimulate staff motivation and improvement process in the enterprise. Proved the importance of the role of choice motivational behavior. In Ukraine, the concept of work motivation in economic terms appeared recently in connection with the democratization of production. Previously, it was used mainly in industrial economic sociology, pedagogy, psychology. Were proposed some measures on coordination manager needed to most effectively motivate employees and ensure the optimal level quality of performance of the work, taking into account the need to meet their needs. Motivational aspects of labor management have been widely used in advanced market economies. During the study identified the needs of workers and their desire, satisfaction of which contribute to their successful work. With proper organization of incentives likely to increase labor productivity, and as a result the organization can rise to a higher level of development.

Keywords: motivation, staff motivation theory, motivation factors, work motivation, behavior model.

Статья посвящена решению проблем поиска модели стимулирования мотивации персонала и усовершенствования прочесса труда на предприятии.

Доказана роль важности выбора мотивационной модели поведения. Были предложены некоторые меры, по координации действий руководителя, необходимые для наиболее эффективной мотивачии работников и обеспечение оптимального уровня качества выполнения ими работы, при учете необходимости удовлетворения их потребностей.

Ключевье слова: мотивачия, персонал, мотивачиионные теории, факторь мотивации, трудовая мотивация, модель поведения.

Вступ.

У сучасному менеджменті все більшого значення набувають мотиваційні чинники. Основна мета процесу мотивації - це отримання максимальної віддачі від використання наявних трудових ресурсів, що дозволяє підвищити загальну 
результативність і прибутковість діяльності підприємства.

В світі, де кожен день на шляху компанії або організації зустрічається безліч конкурентів, де, щоб домогтися успіху, потрібно, йти в ногу 3 часом, роль менеджменту воістину значна, адже суть менеджменту в тому, щоб домогтися кінцевого результату діяльності організації 3 максимальною віддачею на кожному етапі процесу управління і мінімальними витратами.

Постановка проблеми у загальному вигляді та іï зв'язок із науковими та практичними завданнями.

Еволюція застосування різних методів мотивації показала як позитивні, так i негативні аспекти їхнього застосування, i це природний процес, тому що в теорії i практиці управління немає ідеальної моделі стимулювання, яка відповідала б різноманітним вимогам. Існуючі моделі мотивації дуже різні за своєю спрямованістю й ефективністю.

Завжди існувало багато проблем пов'язаних 3 політикою мотивації: проблема взаємовідносин з керівництвом, незадоволеність розміром заробітної плати, умовами побуту та праці в цілому на підприємстві. Головною перешкодою на шляху вирішення цих питань - небажання управлінського персоналу замислюватися про умови життя i праці людей, які безпосередньо створюють прибуток. У ринкових умовах слід приділяти особливу увагу нематеріального стимулюванню, створюючи гнучку систему пільг для працівника.

Актуальність проблем мотивації не оскаржується ні наукою, ні практикою, оскільки від чіткої розробки ефективної системи мотивації залежить не тільки підвищення соціальної і творчої активності конкретного працівника (менеджера, робітника), але і кінцеві результати діяльності підприємств.

Аналіз останніх досліджень i публікацій.

Проблеми мотивації персоналу цікавили вчених протягом усієї історії економічної науки. Питаннями мотивації праці займалися як закордонні, так i вітчизняні автори, зокрема: А.Маслоу, Д.Мак-Грегор, П. Армстронг, А.Кібанов, І.Баткаєва, О.Мітрофанова, М.Ловчева, Ф.Херцберг, Б.Моснер, Б.Снідерман та інші.

У процесі історичного розвитку мотивація як економічна категорія пройшла два етапи:

- застосування політики «батога та пряника»;

- використання методів психології і фізіології.

Суттєвий внесок у розвиток теорій мотивації зробили українські вчені. Так, вчений М.Вольський[2] вважав необхідним поліпшувати фізичні, моральні та інтелектуальні умови існування людини, наголошуючи, що політекономія $\epsilon$ наукою про діяльність людини, спрямовану на задоволення матеріальних $\mathrm{i}$ духовних потреб. Економіст М.Туган-Барановський одним із перших у світі розробив чітку класифікацію потреб[1]. Однак, деякі питання щодо визначення основних мотиваторів персоналу сучасних українських підприємств потребують подальшого системного вивчення

\section{Визначення мети та задачі} дослідження.

Метою дослідження $є$ розробка науково-обгрунтованих рекомендацій щодо удосконалення системи мотивації i організації праці на підприємстві. Досягнення цієї мети потребує вирішення низки завдань, а саме:

вивчення теоретичних основ мотивації трудової діяльності та iï вплив на підвищення ефективності діяльності організації;

- аналіз ролі і значення стимулювання праці в підвищенні ефективності діяльності організації;

- аналіз мотивації трудової діяльності на підприємстві;

- виявлення взаємозв'язків мотивації праці та ефективності діяльності організації;

- визначення шляхів вдосконалення організації праці та мотивації трудової діяльності персоналу.

Для досягнення визначеної мети i завдань у роботі було використано 
загальнонаукові і спеціальні методи дослідження: принципи системного динамічного й процесного підходів та методи якісного аналізу i синтезу при уточненні категорії «конкурентна перевага підприємства» та ознак класифікації видів конкурентних переваг.

\section{Основна частина дослідження.}

Мотиваційні аспекти управління працею набули широкого застосування в країнах з розвиненою ринковою економікою. У нашій країні поняття мотивації праці в економічному сенсі з'явилося порівняно недавно у зв'язку 3 демократизацією виробництва. Раніше воно вживалося, в основному, у промисловій економічній соціології, педагогіці, психології.

Це негативно впливало на мотиваційну особистість працівника, не викликало зацікавленості у власному розвитку, самовдосконаленні, але ж саме ця система сьогодні є найважливішим резервом підвищення ефективності виробництва.

Трудова мотивація - це процес стимулювання окремого виконавця або групи людей до діяльності, спрямований на досягнення цілей організації, до продуктивної виконання прийнятих рішень або намічених робіт [3]

Усі теорії мотивації поділяють на змістові та процесуальні. Змістовні теорії мотивації базуються на потребах та пов'язаних з ними чинниках, що визначають поведінку людей. Процесуальні теорії розглядають теорію в іншому плані. У них аналізується те, як людина розподіляє зусилля для досягнення різних цілей, і як вибирає конкретний вид поведінки. Процесуальні теорії не заперечують існування потреб, але вважають, що поведінка людей визначається не тільки ними. Згідно процесуальним теоріям, поведінка особистості є також функцією його сприйняття і очікувань, пов'язаних 3 даною ситуацією, i можливих наслідків обраного ними типу поведінки.

Для управління працею на основі мотивації необхідно виявити схильності та інтереси працівника 3 урахуванням його персональних та професійних здібностей. Необхідно повніше використовувати особисті цілі учасників трудового процесу і цілі організації.

Ніякі встановлені завдання не викликають зацікавленості людини в активізації своїх зусиль до тих пір, поки вони не перетворяться на його «внутрішню» мету і далі в його «внутрішній» план дії. Тому для кінцевого успіху велике значення має збіг цілей працівника і підприємства.

Мотивацію як процес, можна представити у вигляді ряду послідовних етапів розглянутих на рисунку 1.1 [ 4].

Дуже непросто виявити, які мотиви $€$ вирішальними в мотиваційному процесі конкретної людини в конкретних умовах.

Мотивація як функція управління реалізується через систему стимулів, тобто будь-які дії підлеглого повинні мати для нього позитивні або негативні наслідки 3 точки зору задоволення його потреб або досягнення його цілей. Вивчення колективу може дозволити керівнику створити мотиваційну структуру, за допомогою якої він здійснить виховання колективу в потрібному напрямку.

Таким чином, слід зазначити, що шлях до ефективного управління персоналом лежить через розуміння його мотивації. Тільки знаючи, що рухає людиною, що спонукає іiі до дій, які мотиви лежать в основі його поведінки, можна спробувати розробити ефективну систему форм і методів управління людиною. Для цього необхідно знати, як виникають ті чи інші мотиви, як i якими способами, мотиви можуть бути приведені в дію , як здійснюється мотивування людей.

$\begin{array}{crr}\text { Також } & \text { необхідно } & \text { знати, що } \\ \text { основними } & \text { складовими } & \text { ефективного }\end{array}$ стимулювання праці $є$ стимулювання трудящої людини. На підприємствах, де люди тісно взаємодіють один $з$ одним, при використанні стимулів повинні враховуватися потреби та їх задоволення, підприємливість і інтереси особистості, і навіть характер i спосіб життя. Тоді стимулювання буде по-справжньому дієвим i значущим.

До числа найбільш простих і широко поширених (класичних) теорій мотивації праці, в основі яких лежить специфічна 
картина людини, належить концепція свідомості та мотивації працівників. професора Мічиганського університету Менеджери повинні прагнути розвивати Дугласа МакГрегора, яка зветься «ХУ - групу, якщо вона недостатньо мотивована, теорією». Ця концепція включає дві від стану «Х» до стану «У. У цілому в протилежні теорії: теорію «Х» і теорію «У». поглядах сучасних фахівців і менеджерів на Згідно рекомендації МакГрегора, «ХУ - працівника переважають установки теорії теорію» необхідно використовувати, «У». враховуючи конкретний стан рівня

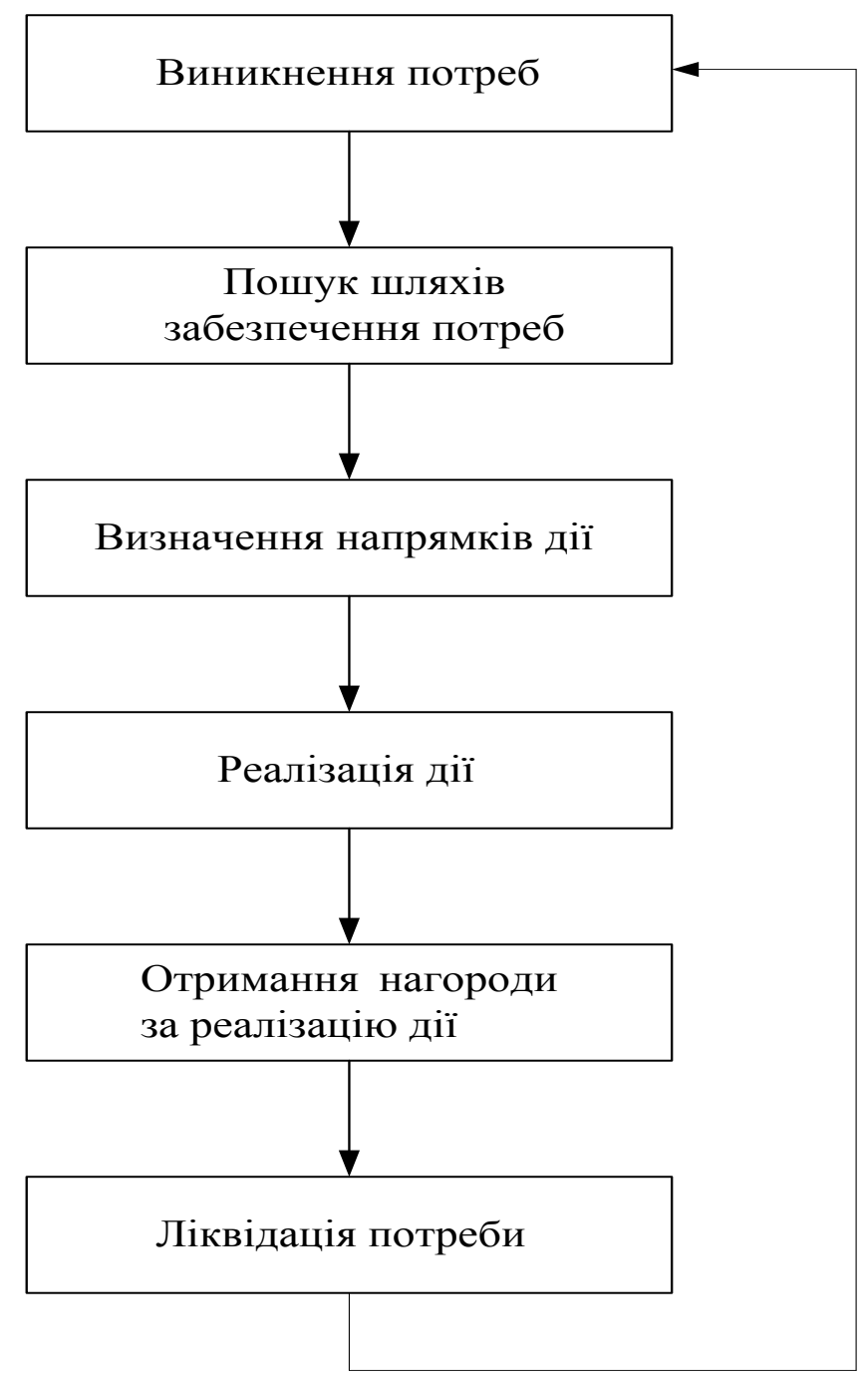

Рисунок 1.1 - Схема мотиваційного процесу

Величезний внесок у розвиток теорії мотивації вніс Абрахам Маслоу (1908-1970), американський психолог, один з лідерів так званої гуманістичної психології.

У кожний конкретний момент часу людина буде прагнути до задоволення тієї потреби, що для неї $\epsilon$ важливішою або сильною.

Фізіологічні потреби (потреби найнижчого рівня) $є$ необхідними для виживання. Вони включають потребу в їжі, воді, захисті, відпочинку, сексуальні потреби.
Потреби в безпеці включають потреби в захисті від фізичних i психологічних небезпек 3 боку навколишнього світу i впевненість у тому, що фізіологічні потреби будуть задовольнятися в майбутньому (покупка страхового полісу або пошук надійної роботи 3 гарними видами на пенсію).

Соціальні потреби (потреби в приналежності, дружбі, любові) включають почуття приналежності до чого-небудь або кого-небудь, підтримки. 
Потреби в повазі включають потреби в особистих досягненнях, компетентності, повазі з боку оточуючих, визнанні.

Потреби в самовираженні, самореалізації - потреби в реалізації своїх потенційних можливостей i зростанні як особистості.

Спочатку споживачі прагнуть задовольнити потреби нижчого рівня, потім можуть думати про задоволення наступної за значимістю потреби. Основний недолік теорії Маслоу зводиться до того, що їй не вдалося врахувати індивідуальні відмінності людей. Виходячи 3 минулого досвіду, одна людина може бути найбільше зацікавлена у самовираженні, у той час як поведінка іншої буде в першу чергу визначатися потребою у визнанні, соціальними потребами.

Теорія Герцберга — це природнє продовження теорії Маслоу: мотиватори сконцентровані на верхніх рівнях ієрархії потреб Маслоу, тоді як гігієнічні фактори являють собою потреби нижніх рівнів.

До мотиваторів Герцберг відніс [5]:

- досягнення;

- визнання успіху;

- інтерес до роботи як такий;

- відповідальність;

- можливість професійного зростання.

До чинників(факторів) контексту

Герцберг відніс:

- спосіб управління;

- політику адміністрації;

- умови праці;

- міжособові стосунки на робочому місці;

- заробітну плату;

- невпевненість в стабільності;

- вплив роботи на особисте життя.

Напевно, найбільш дивним i несподіваним відкриттям, отриманими в результаті проведених Герцбергом досліджень, став той факт, що гроші однозначно були віднесені до розряду гігієнічних чинників, а аж ніяк не мотиваторів. Гроші мають важливе значення для більшості службовців, як через їх купівельної спроможності, так і через статус, який має їх власник. Однак менеджери роблять собі та своїм організаціям погану послугу, коли гроші сприймають як досконалий засіб для задоволення всіх потреб, які можуть виникнути у службовців.

Теорія Герцберга не враховувала впливу багатьох змінних величин на ситуацію. Що може мотивувати однулюдину, не може мотивувати іншу, тобто мотивувати різних людей будуть різні фактори. Згодом вчені дійшли висновку, що для пояснення механізму мотивації необхідно враховувати різноманітні поведінкові аспекти. Це призвело до створення процесуальних теорій мотивації. Основна концепція цих теорій полягає в тому, що поряд 3 урахуванням потреб необхідно брати до уваги те, як людина розподіляє зусилля для досягнення різних цілей і який вид поведінки він вибирає.

Існує безліч різних теорій i моделей мотивації. Серед них можна виділити теорію потреб Абрахама Маслоу, теорію очікувань Віктора Врума, теорію Дугласа МакГрегора, теорію двох факторів Фредеріка Герцберга та інші. Керівникам організацій не варто шукати в цих роботах готових рецептів по мотивування персоналу, але, засвоївши для себе їх основні положення, необхідно виробити для себе свою програму мотивації персоналу. Слід також зрозуміти, що на кожному конкретному підприємстві повинна бути своя специфічна програма, в якій би враховувалися всі особливості діяльності компаніï[6].

У процесі дослідження були виявлені потреби працівників, їх прагнення, задоволення яких сприятиме їх успішній роботі. Слід зазначити, що в ході проведення анкетування було виявлено незадоволеність співробітників одержуваною ними заробітної платою, але багато співробітників показали прагнення до успіху i досягнень. При правильній організації системи заохочень найімовірніше збільшиться рівень продуктивності праці, i як наслідок організація зможе піднятися на вищий рівень розвитку[7].

Висновки 3 дослідження i перспективи, подальший розвиток у даному напрямку.

Економічна ефективність будь-якого виду людської діяльності багато в чому визначається цілями , які переслідуються , 
в їх основі - потреби, інтереси, стимули суб'єктів праці. Методологія їх утворення та функціонування глибоко i всебічно досліджена.

При аналізі проблем організації праці на підприємстві та взаємодії між підрозділами, були запропоновані деякі заходи, щодо координації дій керівника, необхідні для найбільш ефективної мотивації працівників та забезпечення оптимального рівня якості виконання ними роботи, при врахуванні необхідності задоволення їх потреб.

Зроблені висновки не $\epsilon$ остаточними. Вони лише відповідають положенню речей на даний момент часу. Управління організацією i персоналом зокрема - складна і відповідальна робота, i кожен керівник повинен враховувати всі можливі фактори в розробці подібної програми. Саме в цьому запорука успішної роботи співробітників організації, а також ефективної діяльності банку в цілому.

У підсумок слід зазначити, що шлях до ефективного управління персоналом лежить через розуміння його мотивації. Тільки знаючи, що рухає людиною, що спонукає іiі до дій, які мотиви лежать в основі іiі поведінки, можна спробувати розробити ефективну систему форм і методів управління людиною. Для цього необхідно знати, як виникають ті чи інші мотиви, як $\mathrm{i}$ якими способами, мотиви можуть бути приведені в дію, як здійснюється мотивування людей.

\section{Список використаних джерел}

1. Кибанов А.Я., Управление персоналом организации / Под ред. А.Я. Кибанова.-М.: ИНФРА-М, - 2003, с. 483.

2. Кибанов А.Я., Баткаева И.А., Митрофанова Е.А., Ловчева М.В., Мотивация и стимулирование трудовой деятельности. М.: ИНФРА-М, - 2009, с. 524.

3 Макклелланд, Д., Мотивация человека [Текст]: уч. пособие / Д. Макклелланд; пер. с англ. - СПб.: Питер, 2007. - 337 с.

4 Белецкая И.И. Современный механизм формирования конкурентных преимуществ в свете эволюции их теории [Текст]: уч. пособие / И.И. Белецкая. // Прометей. - 2006. - 372с.

5 Офіційний сайт інформаційного порталу «Вікіпедіа» [Електрон. ресурс]. - Режим доступу: - http://uk.wikipedia.org/

6 Кузьмін О.Є. Основи менеджменту: підручник/ О.Є. Кузьмін, О.Г. Мельник. 2-е вид., випр. та допов. - К. : Академвидав,2007. - 464 с.

7 Мазаракі А.А. Менеджмент: теорія і практика : навч. посіб. / А.А. Мазаракі, Г.Є. Мошек, Л.А. Гомба та ін. - К. : Атіка, 2007. - 564 с.

Рецензент д-р економ. наук, професор О.Г.Дейнека

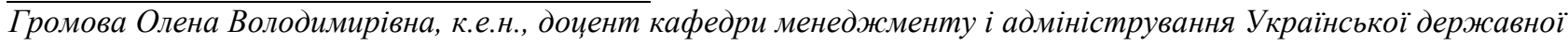
академії залізничного транспорту. Тел. (057) 730-10-46 E-mail: gllo2012@ mail.ru НосикСергій Олександрович, магістрант Tel. (095) 1379990

Gromova Olena Volodumurivna, , d.e.s., lecturer of department of management and administration Ukrainian State Academy of Railway Transport.Tel. (057) 730-10-46 E-mail: gllo2012@mail.ru

Nosik Sergiy, Master's Student Tel. (095) 1379990 
УДК 331.101.262:656.2

\title{
ДОСЛІДЖЕННЯ ТА УДОСКОНАЛЕННЯ СТРАТЕГІЇ ВПРОВАДЖЕННЯ СУЧАСНИХ МЕТОДІВ ОЦІНКИ ТА ВІДБОРУ ПЕРСОНАЛУ
}

Д-р екон. наук В.В. Дикань, магістрант Ю.О. Шаповалов

\section{ИССЛЕДОВАНИЕ И УСОВЕРШЕНСТВОВАНИЕ СТРАТЕГИИ ВНЕДРЕНИЯ СОВРЕМЕННЫХ МЕТОДОВ ОЦЕНКИ И ПОДБОРА ПЕРСОНАЛА}

\author{
Д-р экон. наук В.В. Дикань, магистрант Ю.А. Шаповалов
}

\section{RESEARCH AND IMPROVEMENT OF THE STRATEGY FOR INTRODUCING MODERN METHODS OF ASSESSMENT AND SELECTION OF THE PERSONNEL}

\begin{abstract}
Doct. of ekon. sciences V.V. Dykan, master student Y.O. Shapovalov
Стаття присвячена вирішенню проблем пошуку шляхів удосконалення впровадження сучасних методів очінки та відбору персоналу на підприємствах промислової галузі. Доведено важливу роль промислових підприємств в господарчому комплексі країни та їх значення у здійсненні внутрішньодержавних та зовнішньодержавних економічних зв'язків. Проаналізовано існуючі форми та методи управління персоналом на підприємствах, визначено роль та завдання систем мотивачії персоналу на иляху підвищення продуктивності праці на підприємствах промислової галузі держави.
\end{abstract}

Ключові слова: персонал, мотивачія, ефективність діяльності, трудова діяльність, трудовий потенціал, концеепџія управління.

The article is devoted to the solution of the problems of ways of improving the introduction of modern methods of assessment and selection of personnel at the industrial enterprises. It is proved that the industrial enterprises play an important role in the national economics as well as in the development of the domestic and international economic relations. The focus of the article is on the analysis of the present forms and methods of the management of the personnel at the enterprises with outlining the role and the aim of the system of motivation of the personnel for increasing the productivity of labourat the industrial enterprises.

Keywords: personnel, motivation, productivity of labour, labour activity, the notion of management

Статья посвящена решению проблем путей усовершенствования внедрения современных методов оченки и отбора персонала на предприятиях промышленной отрасли. Доказана важная роль промышленных предприятий в хозяйственном комплексе страны $и$ их значение в осуществлении внутригосударственных $u$ внешнегосударственных экономических связей. Проанализированы существующие формы и методы управления персоналом на предприятиях, определена роль и задачи систем мотивачии персонала на пути повышения продуктивности труда на предприятиях промышленной отрясли государства.

Ключевые слова: персонал,мотивачия, эффективность деятельности, трудовая деятельность, концепция управления.

Вступ.

В умовах становлення сучасної економіки особливе значення мають питання практичного використання ринкових форм управління персоналом на промислових підприємствах, які повинні сприяти підвищенню розвитку трудового потенціалу підприємства.

Як відомо трудовий потенціал - це сукупність здібностей і можливостей кадрів забезпечувати досягнення цілей 
довгострокового (перспективного) розвитку підприємства. Саме тому сучасна концепція управління підприємством передбачає,виділення 3 величезної кількості функціональних сфер управлінської діяльності тієї, яка пов'язана $з$ управлінням кадровою складовою виробництва персоналом підприємства.

Постановка проблеми у загальному вигляді та іiі зв'язок із важливими науковими та практичними завданнями.

У сучасних умовах в країні постає питання реформування промислових підприємств як базової галузі економіки нашої держави. На порядку денному можливі варіанти зміни частково форми власності та коригування адміністративнокомандних методів управління підприємствами. Зазначене потребує не тільки використання в процес і управління підприємством сучасних економічних досліджень, розроблення бізнес планів, використання методології стратегічного планування, а й інших необхідних атрибутів ринкової економіки. Цьому повинно передувати поглиблене вивчення теоретичних та методологічних положень, закономірностей i принципів науки i практики управління,часткове залучення щодо оцінки та відбору персоналу, а також мотиваційних систем які сприятимуть підвищенню ефективності трудового потенціалу підприємств промислової галузі.

Аналіз останніх досліджень і публікацій.

Теоретичні основи ефективного використання трудового потенціалу на базі концепцій якості трудового життя, методів стимулювання та мотивації праці, питання визначення сутності та структури трудового потенціалу представлені в роботах таких вітчизняних i зарубіжних вчених, якВ. Адамчук, П. Друкер, М. Альберт, Х. Ширенбек, Є. Касимовський, Р. Ккаплан, Е. Лоулер, Д. Маркович, А. Маслоу, М. Мескон, Г. Погосян, О. Ромашов, Л. Спенсер, С. Чижова та ін.

Значний внесок у розробку прикладних теоретико-методологічних проблем трудового потенціалу вносять сучасні російські та українські вчені: М.
Бажанова, 3. Бараева, М. Бухалков, Б. Генкін, B. Горбань, Т. Давидюк, В. Довгий, Є. Колесень, Х. Ксенофонтова, А. Кібанов, О. Кузьмін, Є. Маслов, А. Нікітін, Ю. Одєгов, В. Потуданська, С. Радько, Л. Трункіна, Т. Хлопова, Н. Шаталова.

Питання оцінки трудового потенціалу підприємства, мотивації працівників залізничного транспорту досліджені в наукових працях В. Диканя, Д. Ейтутіса, Ю. Слагіна, О. Казаку, В. Козирєва, В. Компанієць, I. Назаренко, О. Пруднікова, Б. Смирнова, Т. Сухорукової, В. Токарєва, Л. Шкуріної та інших вчених.

\section{Визначення мети та задачі дослідження.}

Кардинальні зміни що мають місце в умовах реалізації концепції державної програми реформування промислової галузі, потребують додаткових досліджень саме 3 питань розробки стратгій впровадження сучасних методів оцінки та відбору персоналу на промислових підприємствах, а також розробки методів мотивації для підвищення ефективності трудового потенціалу підприємства. Саме цей аспект $\epsilon$ предметом дослідження, що покладено в основу запропонованої публікації.

Метою передбачуванних дослідженьє розкриття сутності ефективності управлінської діяльності в країні та на промисловому підприємстві ТОВ «МОСПІНСЬКЕ ВПП» а також пошук недоліків в стратегії впровадження сучасних методів оцінки та відбору персоналу з точки зору шляхів їх подолання.

Дослідження зазначених питань формує комплекс задач, які мають включити наступне:

- визначення сутності економічної категорії «трудовий потенціал» на підприємстві ТОВ «МОСПІНСЬКЕ ВПП»;

- аналіз методів підбору, оцінки та відбору персоналу на підприємстві;

- узагальнення досвіду формування i розвитку стратегії впровадження сучасних методів оцінки та відбору персоналу на підприємстві;

- аналіз практики методів відбору та оцінки трудового потенціалу на ТОВ «МОСПІНСЬКЕ ВПП»; 
- розроблення

рекомендацій 3 дослідження мотивів працівників;

- розроблення методичних засад використання KPI для удосконалення системи мотивації персоналу.

\section{Основна частина дослідження.}

На керівництво людьми та прийняття кадрових рішень керівники витрачають більше часу ніж на виконання всіх інших обов'язків [1, с.62].

Звичайно невеликими підприємствами керівники управляють, як правило самостійно. Процес управління великим підприємством відбувається в інших умовах. В управлінській системі таких підприємств зайняті десятки, а іншим разом i сотні людей. Процес управління в такому випадку має бути організований належним чином. Все це потребує від керівників на всіх рівнях адекватної організації процесу управління, яка повинна забезпечити максимально ефективне управління підприємством при мінімальних витратах.

В умовах становлення сучасної економіки особливе значення мають питання практичного використання ринкових форм управління персоналом на промислових підприємствах, які повинні сприяти підвищенню розвитку ефективності трудового потенціалу будь якого підприємства.

Як відомо трудовий потенціал - це сукупність здібностей і можливостей кадрів забезпечувати досягнення цілей довгострокового (перспективного) розвитку підприємства [4 c.112-113]. Саме тому сучасна концепція управління підприємством передбачає,виділення 3 величезної кількості функціональних сфер управлінської діяльності тієї, яка пов'язана 3 управлінням кадровою складовою виробництва - персоналом підприємства [2 c.80-81].

Проте кадрові рішення як правило виявляються самими складними і самими важливими в довгостроковій перспективі, тому існує ряд проблем, які стають на заваді ефективного розвитку та управління кадровим потенціалом у промисловій галузі.
Основною з цих проблем $\epsilon$ якість робочої сили та іiї кваліфікаційний рівень.

Враховуючи демографічну ситуацію в нашій країні, стає можливим зробити висновки, що найбільшим часом наша держава не зможе вирішувати економічні проблеми за рахунок лише простого нарощування чисельності зайнятого населення. В умовах ринкової економіки усе більшого значення набувають саме якісні характеристики трудового потенціалу: кваліфікація, професіоналізм, здатність до отримання знань у продовж життя,рівень культури тощо. Крім того стрімкий розвиток науки i техніки потребує від учасників трудового процесу постійного самовдосконалення. Тому рішення кадрових проблем самі важливі і відповідальні 3 усіх рішень які приймаються керівником. Саме вони визначають потенціал організації і тому їм слід приділяти пріоритетну увагу [1, с.63, 3, с. 36].

ТОВ «Моспінське вуглепереробне підприємство» здійснює збагачення рядового вугілля марки $\mathrm{T}$ i вугілля газових марок $\Gamma$, ДГ 3 метою одержання концентрату для пилоподібного спалювання на теплових електростанціях. Застосовуються такі способи збагачення: важко середовищне збагачення, відсадження. Основні споживачі концентрату: «Східенерго», «Дніпроенерго», «Західенерго».На фабриці використовуються сучасні технології збагачення енергетичного вугілля. Для поліпшення конкурентоспроможності на підприємстві було освоєно збагачення рядового вугілля марок «ДГ», «Г» i антрацитів. Річна виробнича потужність: 2 млн. 500 тис. тонн рядового вугілля. Також до складу підприємства входить дільниця «промислового залізничного транспорту», що виконує комплекс робіт 3 перевезення вантажів, розставляння та пересування вагонів, навантаження та розвантаження вантажів, 3 внутрішніх та технологічних перевезень. В сучасних умовах керівництво розуміє, що одним з ключових елементів економічного успіху на підприємстві $\epsilon$ ефективна оцінка, відбор та управління кадровим потенціалом. Саме тому на підприємстві високо цінується професійний 
досвід, глибокі знання і прагнення людей до самовдосконалення, що відіграє величезну роль у продуктивності праці.

Підтримання необхідного рівня, а також розвиток трудового потенціалу викликає необхідність його регулярної оцінки ТОВ «Моспінське вуглепереробне підприємство» прикладає зусилля для ефективної роботи у сфері оцінки та відбору персоналу. Цей процес передбачає спрямування зусиль для формування кваліфікованого та компетентного штату підприємства[3, с. 40-42].

Підприємство - це не лише колективний інструмент, а й мініатюрне суспільство. Його можна уявити одночасно у вигляді штучної (адже воно створено людиною) та природною системою. Як кожна природна система , підприємство має здатність до еволюції. Однією з вирішальних частин цієї здатності є людські ресурси[3, c.27-28]. Тому при оцінці трудового потенціалу підприємства необхідно виділяти кваліфікаційний, соціальний і мотиваційний потенціал персоналу.

Таким чином, трудовий потенціал $є$ комплексною категорією, найбільш повно характеризує участь людини в процесі праці. Однак на сьогоднішній день склалася безліч точок зору на розуміння сутності трудового потенціалу, що ускладнює його вивчення. Структура трудового потенціалу представлена значним числом компонентів, 3 яких не сформована єдина система, що також ускладнює його вивчення та оцінку. Фактори формування трудового потенціалу підприємства за групами і рівнем впливу $\epsilon$ базою для його оцінки.

Формування дієвої та ефективної методики оцінки трудового потенціалу підприємства утруднено 3 тієї причини, що він характеризується значною кількістю компонентів, для яких, у свою чергу, не існує єдиної методики розрахунку, тому методи оцінки трудового потенціалу носять в основному невизначений характер. Крім того, збір інформації, необхідної для аналізу та оцінки трудового потенціалу, особливо його якісних характеристик, $є$ трудомістким процесом і вимагає спеціальних досліджень.
Проаналізувавши діяльність ТОВ «Моспінське ВПП» щодо застосування методів оцінки та відбору персоналу було визначено, що вона відбувається 3 позиції формування трудового потенціалу підприємства за поширеними оцінками, використовуючи заздалегідь спрощений та частково економічний методи які дають різноманітну характеристику персоналу i представляються різнорідними показниками, які можуть змінюватися різно спрямовано, що ускладнює їх використання в аналітичній роботі.

Стає зрозуміло, що наведені оцінки, які застосовуються на вищевказаному підприємстві, носять дуже спрощений характер та не відповідають навіть традиційному, простому поданню про трудовий потенціал. Сучасний підхід до оцінки трудового потенціалу повинен носити комплексний характер, відбиваючи все різноманіття його природи, при цьому бути досить простим i універсальним у використанні.

Виходячи $з$ представлених міркувань, оцінку стану трудового потенціалу підприємства доцільно виконувати, спираючись на основні положення збалансованої системи показників (ЗСП),яка трансформу $\epsilon$ стратегію, сформульовану керівниками та власниками організації, в завдання і конкретні показники, згруповані за різними напрямками [5, с.92-93]. Загальна стратегія, проміжні цілі та конкретні показники, що характеризують ступінь їх реалізації, формують ланцюг причиннонаслідкових взаємозв'язків.

Але наскільки авторитарною не була б організація, вона повинна задовольняти амбіції і потреби своїх членів і робити це по відношенню до них як до індивідів [1, с.64].

Керівництво організації може розробити чудові плани і стратегії, знайти оптимальні структури і створити ефективні системи передачі та обробки інформації, встановити в організації саме сучасне обладнання і використовувати самі сучасні технології. Але все це буде зведено на нівець, якщо всі члени організації не будуть працювати належним чином, не будуть своїм 
трудом сприяти досягненню організацією своїх цілей і виконанню своєї місії.

Готовність i бажання персоналу виконувати свою роботу являються одним 3 ключових факторів успіху функціонування організації. Таким чином стає зрозуміло, що шлях до ефективного керування персоналом лежить через розуміння його мотивації. дії людини.

Мотив - це те, що викликає визначені

Мотивація - це сукупність внутрішніх i зовнішніх рухомих сил, які спонукають людину до діяльності, завдають кордони і форми діяльності і надають цієї діяльності спрямованість, орієнтовану на досягнення визначених цілей. Тільки знаючи те, що мотивує людину, що спонукає пї до діяльності, які мотиви лежать в основі іiї дій, можливо розробити систему мотивації, яка буде сприяти підвищенню ефективності використання трудового потенціалу підприємства.

У зарубіжній та вітчизняній науковій літературі висвітлені різноманітні концепції та підходи щодо розробки та удосконалення системи мотивації, а саме через виконання ключових показників ефективності КРІ.

KPI (Key Performance Indicators) переклад 3 англійської „ключовий показник ефективності". КРІ дозволяє здійснювати контроль активності через систему ключових показників ефективності. Ключові показники ефективності - це показники, які максимально характеризують результати діяльності підрозділу (ступінь досягнення мети) і впливають на мотивацію персоналу.

Вона складається з трьохпідсистем:

- матеріальна мотивація;

- нематеріальна мотивація;

- персональна відповідальність і контроль.

Підсистема матеріальної мотивації містить стимули, спрямовані на задоволення матеріальних потреб і включає: премії i матеріальне заохочення співробітників; оптимізован ібазові оклади; наявність соціального пакету. Підсистема нематеріальної мотивації складається 3: кар'єрного зростання; професійного зростання i розвитку. Для створення підсистеми відповідальності і контролю розробляється

комплекс

ключових показників діяльності компанії і робиться їх "прив'язка" до керівників підрозділів i кінцевих виконавців. Створення такої системи потрібне, щоб фокусувати роботу кожного співробітника на досягнення поставлених цілей.

Характерною рисою КРІ $є$ система, яка використовується для досягнення головних цілей будь-якого бізнесу, таких як залучення і утримання споживачів (клієнтів), зростання професіоналізму співробітників, збільшення доходів і зниження витрат. Особливістю мотивації персоналу на базі KPI, $\epsilon$ орієнтація на досягнення довгострокових i короткострокових цілей підприємства, мотивація на виконання посадових обов'язків самого працівника. Як слід, поліпшення ефективності роботи працівника відкриває гігантські можливості для збільшення продуктивності праці та отримання більш високих результатів для самого підприємства.

Таким чином, шляхом використання на промислових підприємствах системи мотивації на базі КРI можливо відновити основні функції заробітної плати, підвищити мотиваційний та трудовий потенціал працівників цих підприємств, їх зацікавленість у зростанні ефективності індивідуальної та колективної праці.

\section{Висновки 3 дослідження i перспективи, подальший розвиток у даному напрямку.}

Отже, зважаючи на провідну роль промислових підприємств як базової галузі економіки нашої держави, та зміни частково форми власності, а також коригування адміністративно-командних методів управління підприємствами на порядку денному необхідні розробки варіантів впровадження не тільки використання в процесі управління підприємством сучасних економічних досліджень. Вважаємо за необхідне застосування сучасних методів розробки стратегій оцінки i відбору персоналу, а також впровадження на них мотиваційних систем як засобів підвищення ефективності використання трудового потенціалу підприємства. передувало поглиблене Цьому вивчення 
теоретичних та методологічних положень, закономірностей i принципів науки i практики управління,часткове залучення щодо оцінки та відбору персоналу, а також мотиваційних систем які сприятимуть підвищенню ефективності трудового потенціалу підприємств промислової галузі.

\section{Список використаних джерел}

1. Друкер,Питер, Ф. Энциклопедия менеджмента.: Пер. с англ.-М.: Издательский дом «Вильямс», 2004. - 432с.: ил. - Парал. тит. англ.

2. Базаров,Т.Ю. Управление персоналом [Текст]: Т.Ю.Базарова. -М.:ЮНИТИ, 2006.$560 \mathrm{c}$.

3. Крушельницька, О.В. Управління персоналом [Текст]: навч. Посібник/ О.В. Крушельницька, Д.П. Мельничук, - К.: Кондор, 2003. - 296с.

4. Линенко, А. В. Сутність й аналіз трудового потенціалупідприємства за показникамиефективностійоговикористання [Текст] / А. В. Линенко, О. Л. Шевченко // Держава та регіони. Серія: Економіка та підприємництво. - 2008. - № 4. - С. 111-116.

5. Каплан Роберт С. Сбалансированная система показателей. От стратегии к действию [Текст]: пер. с англ. / Роберт С. Каплан, Дейвид П. Нортон. - М.: ЗАО «ОлимпБизнес», 2007. - 320 c.

6. Колесень, Е. В. Оценка трудового потенциала промышленного предприятия [Текст] / Е. В. Колесень // Вестник Пермского университета. - 2012. - Сер. «Экономика». Вып. 1(12). - С. 112-119.

Дикань Валерія Володимирівна, д.е.н., професор кафедри менеджменту і адміністрування Українська державна академія залізничного транспорту. Тел. (057)730-10-46 E-mail: valeriya@hotbox.ru

Шаповалов Юрій Олександрович, Магістрант

Dykan Valeriia Volodymyrivna, d.e.s., professor department of management and administration Ukrainian State Academy of Railway Transport. Tel.: (057)730-10-46 E-mail: valeriya@ hotbox.ru

Shapovalov Yuriy Oleksandrovuch, Master's Student

УДК 330.123.6:654.1

\section{ШЛЯХИ ЗАБЕЗПЕЧЕННЯ ЯКОСТІ ПОСЛУГ МОБІЛЬНОГО ЗВ'ЯЗКУ НА ПРИКЛАДІ КОМПАНІЇ «МТС УКРАЇНА»}

Магістрант Ліснича I. А.

\section{ПУТИ ОБЕСПЕЧЕНИЯ КАЧЕСТВА УСЛУГ МОБИЛЬНОЙ СВЯЗИ НА ПРИМЕРЕ КОМПАНИИ «МТС УКРАИНА»}

Магистрант Лесничая И. А.

\section{WAYS OF ENSURING THE QUALITY OF MOBILE SERVICES FOR EXAMPLE COMPANY "MTS UKRAINE"}

Master student Lesnichaya I. A.

Стаття присвячена питанням забезпечення якості послуг мобільного зв'язку шляхом вдосконалення системи якості в компанії «МТС Украӥна». Визначено, щуо система управління якістю необхідна для того, щэоб споживачі і керівництво компанії були упевнені 8 ї̈ здатності ефективно надавати якісні послуги на протязі тривалого часу, незважаючи на зміну технологій, постачальників, співробітників і т.д. 
Ключові слова: мобільний зв'язок, послуги, якість, обслуговування, надійність, споживачі, система якості, інформачія, менеджмент, стратегія

Статья посвящена вопросам обеспечения качества услуг мобильной связи путем совершенствования системы качества в компании «МТС Украина». Определено, что система управления качеством необходима для того, чтобы потребители и руководство были уверень в ее способности эффективно предоставлять качественные услуги на протяжении длительного времени, несмотря на смену технологий, поставщиков, сотрудников и т.д.

Ключевые слова: мобильная связь, услуги, качество, обслуживание, надежность, потребители, система качества, информация, менеджмент, стратегия

The speed and scale of the development and dissemination of informational communications, their influence on the cultural, social, economic and political transformation in the society give the basis to assess the nature and open a new era in the history of human civilization. One of the types of information communications mobile communication, because it is a new level of comfort and freedom of communication, it is an opportunity to organize their lives to care about what is important to us. The pace of modern life and the demands that it puts before us, make mobile communication our reliable and indispensable partner, who accompanies us throughout the day. he operator of the mobile communication consists meet the needs of its clients in any communication services. The provision of these services agreed engaged in several major departments of the operator. Their institutional and technological framework is the infrastructure for providing services. Daily activities infrastructure of communications services focused on providing services to as many clients at a fixed manageable level of quality and minimizing internal costs. In order to control the level of quality, the company should support the full life cycle of services that consists of several interacting steps.

Keywords: mobile communications, services, quality, service, reliability, consumers, system quality, information, management, strategy

Постановка проблеми та ї зв'язки з науковими чи практичними завданнями. Кінець 20-го та початок 21-го століть ввійдуть в історію як переломний рубіж у розвитку світової цивілізації. Глибокі зміни охопили всі основні сфери життєдіяльності суспільства, держави, а також не промайнули вони сферу інфраструктури, адже діяльність людей в основних аспектах суспільного життя здійснюється 3 неодмінним залученням засобів відповідної розвиненої інфраструктури.

Швидкість і масштаби розвитку та поширення інфокомунікацій, їх вплив на культурні, соціальні, економічні та політичні трансформації в суспільстві дають підстави оцінювати характер і відкривають нову еру в історії людської цивілізації.

Одним 3 видів інфокомунікацій $\epsilon$ мобільний зв'язок, тому що це новий рівень комфорту і свободи спілкування, це можливість організовувати своє життя, піклуватися про близьких і про те, що є для нас важливим. Темпи сучасного життя i ті вимоги, які воно ставить перед нами, роблять мобільний зв'язок нашим надійним і необхідним партнером, який супроводжує нас протягом усього дня.

Кількість підприємств, що прагнуть закріпитись у галузі мобільного зв'язку зростає, тому що галузь приваблює високим рівнем прибутку, стійким попитом на послуги. Підприємства, які нещодавно прийшли в галузь пропонують послуги по більш низьким цінам та низькою якістю. Така тенденція може привести до непропорційного росту споживчого попиту відносно пропозиції в цілому по галузі.

В умовах жорстокої конкурентної боротьби й швидко мінливої ситуації підприємства повинні не тільки зосереджувати увагу на внутрішньому стані справ, але й розробляти довгострокову стратегію підвищення якості пропонованих товарів чи послуг, що дозволяла б їм 
встигати за змінами зовнішнього середовища.

Аналіз останніх досліджень $i$ публікацій та виділення невирішених частин загальної проблеми. На сьогоднішній день якість відображає діяльність підприємства через створення якісної продукції або надання послуг, спрямовану на завоювання нових споживачів та утримання існуючих. У роботах вчених якість послуг характеризується як один із найважливіших показників розвитку підприємства, пропонуються підходи до ï оцінки та підвищення [1-5]. Адже досягнення якості - це не питання використання особливого методу або технологічних засобів; воно вимагає зміни у філософії менеджменту та культури організації.

Mema cmammi заключається у дослідження якості послуг мобільного зв'язку через удосконалення системи якості в компанії.

Виклад основного матеріалу досліджсення. На сьогодні у світі створена нова стратегія, яка трактує якість як найбільш важливий фактор в забезпеченні конкурентноздатності будь-якої компанії. У зарубіжній практиці виділяють такі два основних елементи стосовно якості: відповідність цілям проекту та відповідність вимогам споживачів. 3 переходом до ринкових відносин в Україні проблема якості постала перед кожним виробником. Саме вирішенням цієї проблеми повинен займатись проект-менеджер.

Більшість великих сервісних компанії в Україні ініціювали в себе одну 3 програм якості. Серед них найбільш типовими є [1]:

- тотальне управління якістю [TQM] 3 акцентом на базові інструменти контролю якості [блок-схеми, діаграми причинно-наслідкових зв'язків та діаграми Парето];

- сертифікація ISO 9000, що покликана стимулювати стандартизацію та розвиток процесно-орієнтованого мислення у галузі;

- використання

критеріїв

Національної відзнаки за якість 3 метою комплексного конкурентноздатності

компаній уданій галузі;

- застосування методології 6 сигма для підвищення ефективності бізнесу.

Компанія «МТС Україна», як одна 3 провідних компаній, що надає послуги мобільного зв'язку на території нашої держави [6], може використовувати більше, ніж одну із зазначених програм. Однак, незалежно від того, які з них були обрані, ці програми необхідно обов'язково узгоджувати із операційною стратегією компанії. А операційна стратегія, у свою чергу, повинна відповідати загальній корпоративній стратегіï.

Операційну стратегію визначають специфіка бізнесу, життєвий цикл сервісної пропозиції та інші фактори бізнессередовища. Зазвичай операційна стратегія розробляється на основі ціни, властивостей, часу реакції системи та рівня індивідуалізації продукту. Відповідно, кожен крок вибраної програми має відповідати операційній стратегії компанії.

Таким чином, діяльність оператора мобільного зв'язку складається із задоволення потреб своїх клієнтів у комунікаційних послугах. Наданням даних послуг узгоджено займаються кілька основних департаментів оператора. Їх організаційна й технологічна структура являє собою інфраструктуру забезпечення послуг. Умовна схема взаємодії елементів цієї інфраструктури із клієнтами компанії представлена на рис. 1. Повсякденна діяльність інфраструктури забезпечення послуг зв'язку спрямована на надання послуг як можна більшому числу клієнтів при фіксованому керованому рівні якості й мінімізації внутрішніх витрат. Для того щоб управляти рівнем якості, компанія повинна підтримувати повний життєвий цикл послуги, що являє собою сукупність декількох взаємодіючих етапів.

3 погляду клієнтів, оператор мобільного зв'язку - це єдиний центр по наданню послуг, тому департаменти (відділи), залучені в діяльність по наданню послуг, повинні працювати узгоджено й домагатися високої якості послуг. Отже, повинні існувати чіткі регламенти такої 
діяльності. Найбільш ефективним підходом до іiі організації $\epsilon$ процесний підхід, зображений на рис. 2.

У першу чергу компанії мобільного зв’язку варто зосередитися на організації й автоматизації тих процесів, які у відносній оцінці мають найбільший вплив на клієнтів оператора мобільного зв'язку й володіють найбільшою ресурсомісткістю.

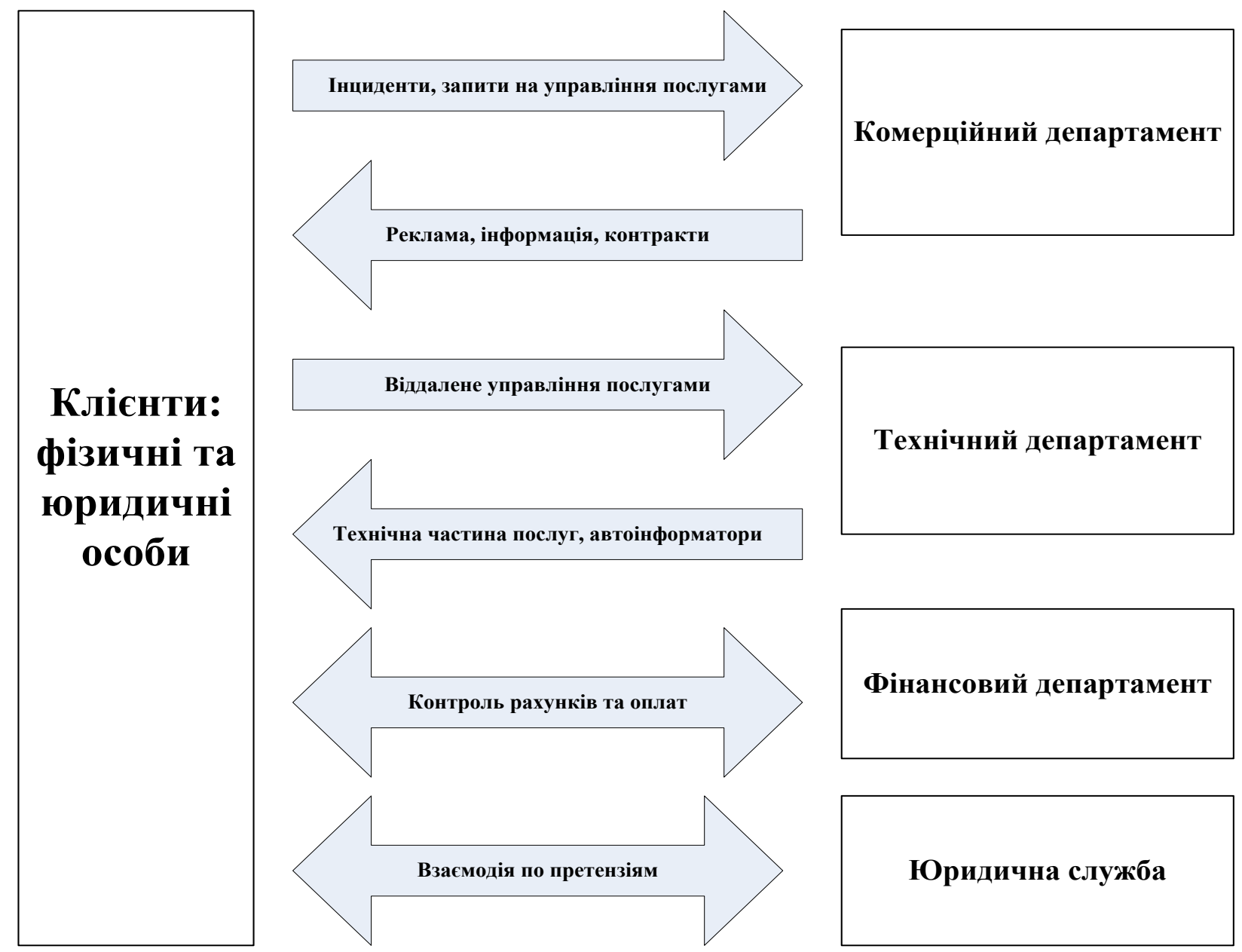

Рисунок 1 - Схема взаємодії елементів організаційної й технологічної структури оператора мобільного зв'язку

На рис. 3 представлена схема інтеграції цих процесів 3 інфраструктурою забезпечення послуг оператора мобільного зв'язку.

Впровадження в діяльність оператора мобільного зв'язку - компанії «МТС Україна» - схеми інтеграції, наведеної на рис. 3 , дозволить їй постійно й систематично здійснювати контроль стану інфраструктури забезпечення послуг i створить базу для повноцінного керування рівнем якості послуг.

Доцільність першочергової роботи саме над цими процесами визначається тим, що на повсякденну діяльність по цих напрямках компанія «МТС Україна» витрачає до $90 \%$ наявних ресурсів. Отже, підвищення ефективності цієї діяльності, отриманої за рахунок іiï автоматизації й формалізації, дасть найбільший економічний ефект.

Висновки. Телекомунікації відіграють значну роль в соціальній та економічній діяльності суспільства, забезпечуючи оперативне або інтерактивне (діалогове) передавання інформації. Розвиток телекомунікацій повинен здійснюватися випереджувальними темпами порівняно із загальними темпами розвитку економіки та буде визначальним на найближчу i більш віддалену перспективу. Основою такого розвитку повинна стати система якості. 
Адже система управління якістю регламентує дії всіх співробітників підприємства, що можуть вплинути на якість послуг, що надаються і на задоволеність споживачів.

Вимоги до системи управління якістю висуваються для того, щоб споживачі i керівництво були упевнені в здатності компанії ефективно надавати якісні послуги протягом тривалого часу. За цей час може мінятися технологія, постачальники, співробітники i т.д., але це не повинно позначатися на якості продукції. Таким чином, система вимагає постійної підтримки, доробки, вдосконалення, тому що підприємство працює в постійно змінюваних внутрішніх і зовнішніх умовах, що потребує також зміни його діяльності.

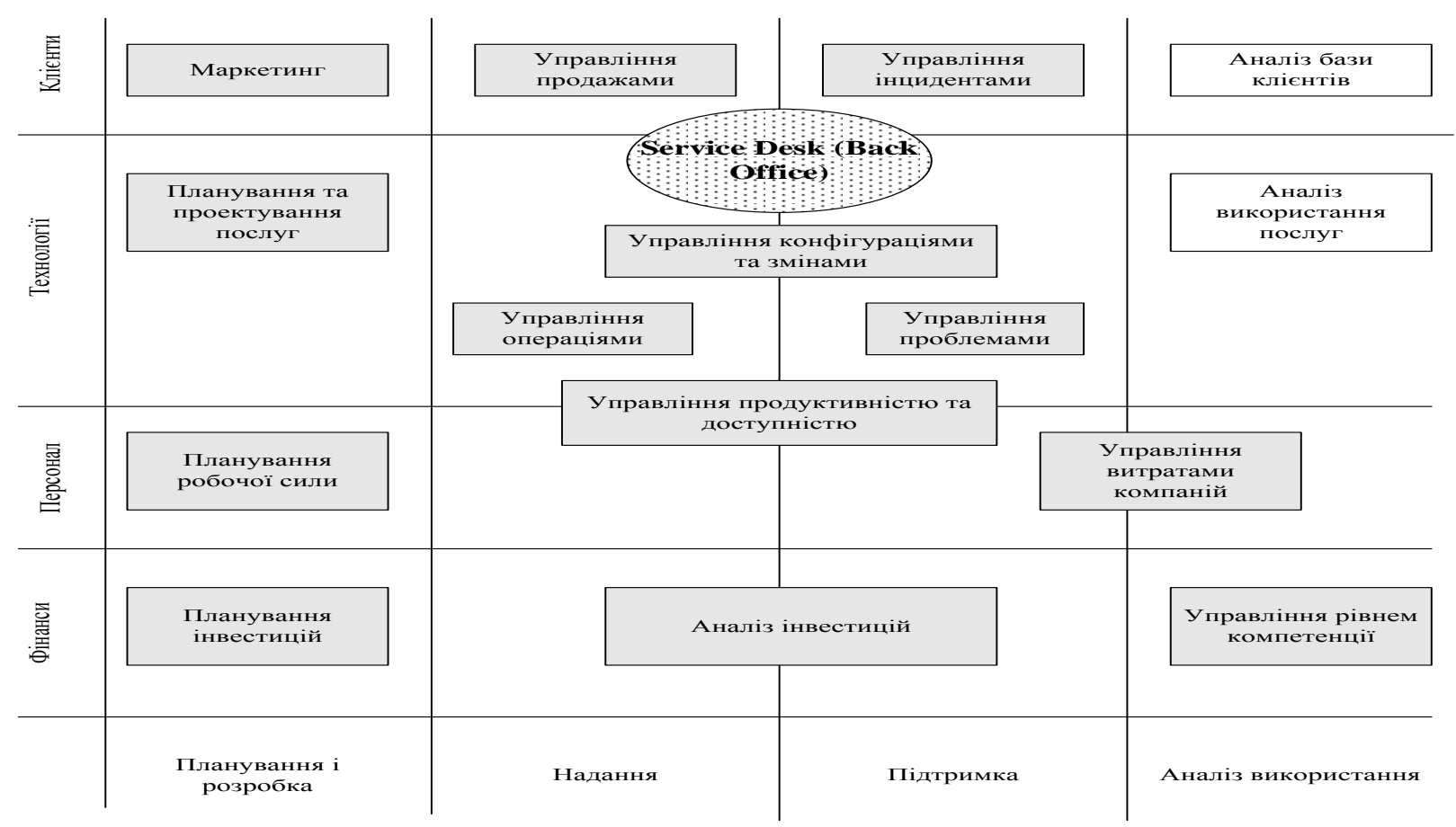

Рисунок 2 - Схема діяльності оператора мобільного зв’язку

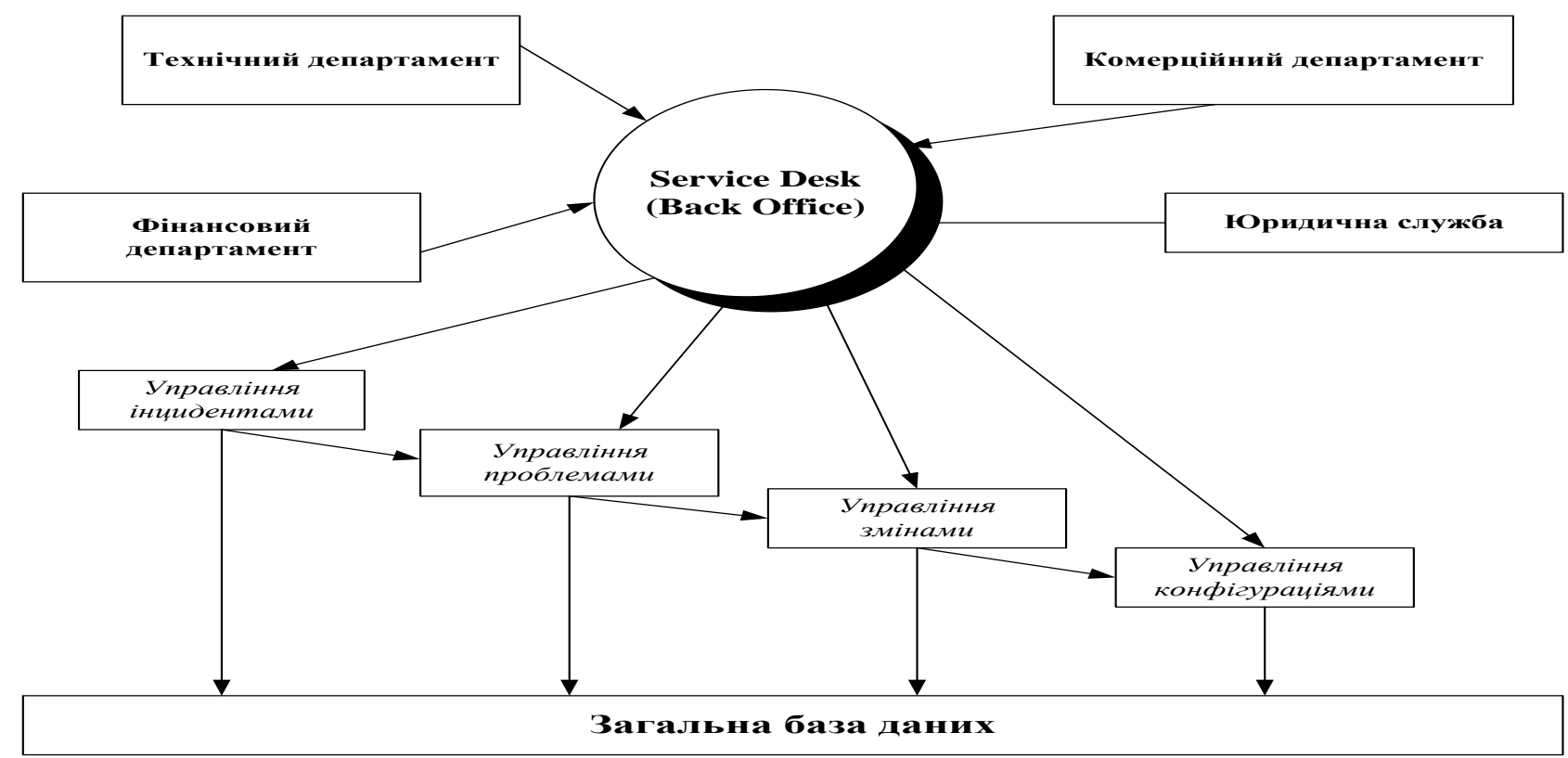

Рисунок 3 - Схема інтеграції бізнес-процесів з інфраструктурою забезпечення послуг оператора мобільного зв'язку 


\section{Список використаних джерел}

1 Шаповал М. І. Менеджмент якості : навч. посібник / М. І. Шаповал. - К. : Знання, 2007. - $471 \mathrm{c}$.

2 Шеер А. В. Бизнес-процессы. Основные понятия. Теория. Методы [Текст] / А. В. Шеер. - М. : Весть-Мета Технология, 2000. - 152 с.

3 Копнов В. А. Стратегічний менеджмент якості. Методичні вказівки по ефективній побудові систем менеджменту якості / В. А. Копнов // Технології якості життя. - 2003. - Т. № 3 - 4. - С. 69 - 89 .

4 Алферов Н.П. Управление качеством: ученик/ Н.П. Алферовв - М.: ИНФРА-М, 2003. $-374 \mathrm{c}$.

5 Огвоздин В.Ю. Управление качеством. Основы теории и практики [Текст]: учебное пособие / В.Ю. Огвоздин. - М. : Изд. Дело и Сервис 1999. - 160 с.

6 Про компанію. Профайл МТС [Електронний ресурс]. - Режим доступу: mts.com.ua

Рецензент д-р екон. наук, професор В.В.Компанієць

Ліснича Ірина Анатоліївна, слухач НН ІППК Украӥнської державної академії залізничного транспорту, експерт по роботі з корпоративних продаж ПрАТ «МТС-Украӥна»,050-321-55-05

Lesnichaya Irina Anatolievna, the listener NN Institute of Ukrainian state Academy of railway transport, expert in corporate sales PrJSC "MTS Ukraine",050-321-55-05

УДК 330.341.1:656.2

\section{СУТНІСТЬ І СТРУКТУРА КАДРОВОГО ПОТЕНЦАЛУ ЗАЛІЗНИЧНОГО ТРАНСПОРТУ}

магістрант Погрібна Я.Д.

\section{СУЩНОСТЬ И СТРУКТУРА КАДРОВОГО ПОТЕНЦИАЛА ЖЕЛЕЗНОДОРОЖНОГО TРАНСПОРТА}

магистр Погребная Я.Д

\section{ESSENCE AND STRUCTURE OF SKILLED POTENTIAL OF RAILWAY TRANSPORT}

master student Pogribna Y. D.

В статті на основі аналізу існуючих визначень з'ясовано, щуо кадровий потенціал залізничного транспорту - ие сукупність спроможностей працівників залізничного транспорту максимально ефективно виконувати свої обов'язки $і$ виробляти високоякісні транспортні та інші послуги, роботи, продукцію для задоволення потреб економіки та населення у вантажних $і$ пасажирських перевезеннях $i$ отримання прибутку. Крім того, визначена структура кадрового потенціалу залізничного транспорту.

Ключові слова: кадровий потенціал, залізничний транспорт, структура кадрового потенціалу.

В статье на основе анализа существуюших определений выяснено, что кадровый потенциал железнодорожного транспорта - это совокупность возможностей работников железнодорожного транспорта максимально эффективно выполнять свои обязанности $и$ производить высококачественные транспортные и другие услуги, работы, продукиию для удовлетворения потребностей экономики и населения в грузовых и пассажирских перевозках и получения прибыли. Кроме того, определена структура кадрового потенциала железнодорожного транспорта. 
Ключевые слова: кадровый потенциал, железнодорожный транспорт, структура кадрового потенцииала.

In the article it is found out on the basis of analysis of existent determinations, that skilled potential of railway transport - it totality of possibilities of workers of railway transport to execute the duties maximally effectively and to produce high-quality transport and other services, works, products for satisfaction of necessities of economy and population in freight and passenger transportations and receipt arrived.

In addition, the structure of skilled potential of railway transport is certain due to addition of new signs. So, on a functional sign potentials of workers of locomotive service, carriage service, service of signaling and connection, technical service, service of transportations, passenger service, service of railtrack, financial-economic service, power supply service and other services are distinguished. On the specific of works (in accordance with Classifier of professions) potentials of workers of the first group (leaders), second group (specialists) and other groups (in all they nine) are distinguished. On the level of education potentials of workers, having a graduate degree or master's degree diploma, workers with higher education, workers, are distinguished with the secondary special education, other workers.

Keywords: skilled potential, railway transport, structure skilled.

Постановка проблеми та ї̈ зв'язки з науковими чи практичними завданнями. У залізничній галузі триває реформування: 25 червня 2014 р. Кабінет міністрів України прийняв постанову №200 «Про утворення публічного акціонерного товариства "Українська залізниця", згідно 3 якою найближчим часом повинно бути створене ПАТ “Українська залізниця", з урахуванням Закону України "Про особливості утворення публічного акціонерного товариства залізничного транспорту загального користування» від 23.02.2014 p. Тому особливої актуальності набуває проблема підвищення ефективності діяльності галузі, при збереженні iii кадрового потенціалу. Вже більше року на залізничному транспорті триває оптимізація кадрового потенціалу для приведення чисельності персоналу і його якісного складу у відповідність з обсягами перевезень і робіт, оновленими технологічними процесами. Але, як наголошено у [1], під час оптимізації чисельності персоналу не можна допустити погіршення його якісних, структурних та інших характеристик.

Тому необхідним $є$ дослідження сутності, структури і методик оцінювання кадрового потенціалу залізничного транспорту, на основі якого 3 урахуванням науково обгрунтованих вимог повинні розроблятися заходи 3 оптимізації та підвищення ефективності використання кадрового потенціалу.
Аналіз останніх досліджень $\boldsymbol{i}$ публікацій та виділення невирішених частин загальної проблеми. Висвітленню питань управління трудовим потенціалом присвятили свої праці провідні вітчизняні вчені: Д. Богиня, С. Вовканич, В. Гавва, А. Гальчинський, О. Грішнова, I. Джаїн, М. Долішній, С. Жулавський, М. Ким, А. Колот, T. Костишина, Н. Краснокутська, О. Крушельницька, Є.Лапін, О. Новікова, О. Олексюк, Г. Осовська, В. Пономаренко, С. Радько, І. Рєпіна, М. Семикіна, І. Точенов, О. Федонін, М. Чумаченко [2 - 10] та інші.

Проблеми формування та використання трудового потенціалу, визначення його структури, оцінки використання в процесі трудової діяльності висвітлено у праціях вчених близького зарубіжжя: С. Агапцова, С. Андрєєва, Б. Генкіна, В. Вєсніна, Д. Дячкова, О. Іванілова, А. Сгоршина, А. Кібанова, Е. Ленского, Ю. Одегова, І. Плєтникової (Назаренко) [1, 10] , Г. Сергєєвої, В. Травіна та інших. Аналіз наукових праць, що висвітлюють питання використання трудового потенціалу, показав, що ця проблема ще не достатньо вивчена та науково обгрунтована. Вченими не визначено єдиного підходу щодо застосування категорійного апарату, методики оцінювання використання трудового потенціалу підприємства та системи чинників, під впливом яких відбуваються процеси його формування. Тому існує об'єктивна 
необхідність у пошуку єдиного визначення сутності поняття «кадровий потенціал».

Метою cmammi $€$ визначення сутності поняття «кадровий потенціал залізничного транспорту» та його структури.

Виклад основного матеріалу дослідження. В теперішній час не існує єдиного підходу до трактовки поняття „трудовий (кадровий) потенціал”. Розглянемо деякі визначення даної економічної категорії, наявні в літературі.

Трудовий потенціал - це найбільш повна характеристика всіх здібностей до праці, якими володіє індивід, колектив i суспільство в цілому. Поняття трудового потенціалу узагальнює всебічну характеристику ресурсів, включаючи кількісні та якісні параметри здатностей до трудової діяльності, в тому числі ті фактори, які не піддаються виміру, наприклад, моральність, менталітет [3, с. 13].

Трудовий потенціал - це існуючі сьогодні та передбачувані трудові можливості, які визначаються чисельністю, віковою структурою, професійними, кваліфікаційними та іншими характеристиками персоналу підприємства [4, c. 197].

Трудовий потенціал виступає як інтегральна характеристика здібностей до праці (в їх кількісному i якісному відношенні), яка визначає можливості як конкретного робітника, так i сукупного робітника по їх участі у суспільно корисній діяльності [5, с. 38].

Трудовий потенціал - це „основана на професійних знаннях, практичних навичках, особистісних i психофізиологічних характеристиках робітників спроможність персоналу реалізовувати цілі підприємства при належному матеріально-технічному, інформаційному і організаційному забезпеченні процесу праці” [6, с. 31] .

Кадровий потенціал - це сукупність здібностей i можливостей кадрів забезпечувати досягнення цілей довгострокового (перспективного) розвитку підприємства [7, с. 239].

Кадровий потенціал підприємства - це спроможність і можливість персоналу фірми (підприємства) до повної реалізації свого особистісного потенціалу для досягнення поставлений цілей при виробництві товарів та послуг. При цьому під потенціалом особистості розуміється комплексна характеристика індивідуума, яка включає кваліфікаційний, освітній i інтелектуальний рівні, a також спроможність їх використовувати і розвивати з часом $[8$, c. 69 71].

По визначенню А.Ю.Жулавського i Є.В. Лапіна, кадровий потенціал підприємства - це ,сукупна спроможність виробничого персоналу забезпечити виробництво споживчих вартостей, які відповідають потребам ринку в конкретних економічних i науково-технічних умовах виробництва" [9, с. 168].

Як бачимо, всі вищенаведені визначення кадрового потенціалу містять його характеристику - здібність до праці, до вироблення суспільно корисної продукції.

Інтегрує вищенаведене, у [10] надано визначення сутності категорії „кадровий потенціал підприємства" як сукупності спроможностей працівників підприємства максимально ефективно виконувати свої обов'язки і виробляти високоякісні послуги, роботи, продукцію для задоволення потреб суспільства і досягнення цілей підприємства. Вважаємо це визначення найбільш адекватним.

Стосовно кадрового потенціалу залізничного транспорту, то існує визначення О. Познякової [11, с. 123]: «це сукупність здібностей усіх працівників, зайнятих в наданні послуг перевезення залізничним транспортом; це їх можливості, що можуть бути реалізовані в процесі трудової діяльності».

На нашу думку, це визначення $\epsilon$ неповним: по-перше, в ньому відображені лише працівники, безпосередньо зайняті в наданні послуг перевезення залізничним транспортом (без урахування тих, хто зайнятий на підсобно-допоміжній діяльності), а це $\epsilon$ некоректним, адже підприємства залізничного транспорту виробляють ще i допоміжні послуги та продукцію, не пов'язані 3 перевезеннями; по-друге, «можливості, що можуть бути реалізовані в процесі трудової діяльності» - це неточне, розпливчасте 
формулювання. Тому сформулюємо кадровий потенціал залізничного транспорту на базі визначення [10] як сукупність спроможностей працівників залізничного транспорту максимально ефективно виконувати свої обов'язки i виробляти високоякісні транспортні та інші послуги, роботи, продукцію для задоволення потреб економіки та населення у вантажних і пасажирських перевезеннях і отримання прибутку.

В літературі виділяють складові кадрового потенціалу підприємства індивідуальний кадровий потенціал (окремого працівника) та кадровий потенціал колективу (який складається 3 потенціалу організації праці та потенціалу системи управління). Крім того, індивідуальний кадровий потенціал поділяють на фізіологічний, освітній (включає загальноосвітній та професійнокваліфікаційний), інтелектуальний та культурно-особистісний.

А. В. Линенко i О. Л. Шевченко розглядають структуру трудового потенціалу підприємства за наступними критеріями:

- за рівнем агрегованості оцінок (трудовий потенціал працівника; груповий трудовий потенціал; трудовий потенціал підприємства);
- за спектром охоплення можливостей (індивідуальний трудовий потенціал; колективний трудовий потенціал);

- за характером участі у виробничогосподарському процесі (потенціал технологічного персоналу; управлінський потенціал);

- за місцем у соціально-економічній системі підприємства (структурноформувальний трудовий потенціал; підприємницький трудовий потенціал; продуктивний трудовий потенціал.

Базуючись на вищевикладеному, а також 3 урахуванням специфіки діяльності залізничного транспорту, нами розроблено структуру кадрового потенціалу залізничного транспорту (рис. 1).

Висновки. Визначено, що кадровий потенціал залізничного транспорту - це сукупність спроможностей працівників залізничного транспорту максимально ефективно виконувати свої обов'язки i виробляти високоякісні транспортні та інші послуги, роботи, продукцію для задоволення потреб економіки та населення у вантажних і пасажирських перевезеннях i отримання прибутку. Визначено також його структуру (до існуючих в літературі додані ознаки: за функціональною ознакою, за специфікою робіт, за рівнем освіти). 
Експлуатація залізниць

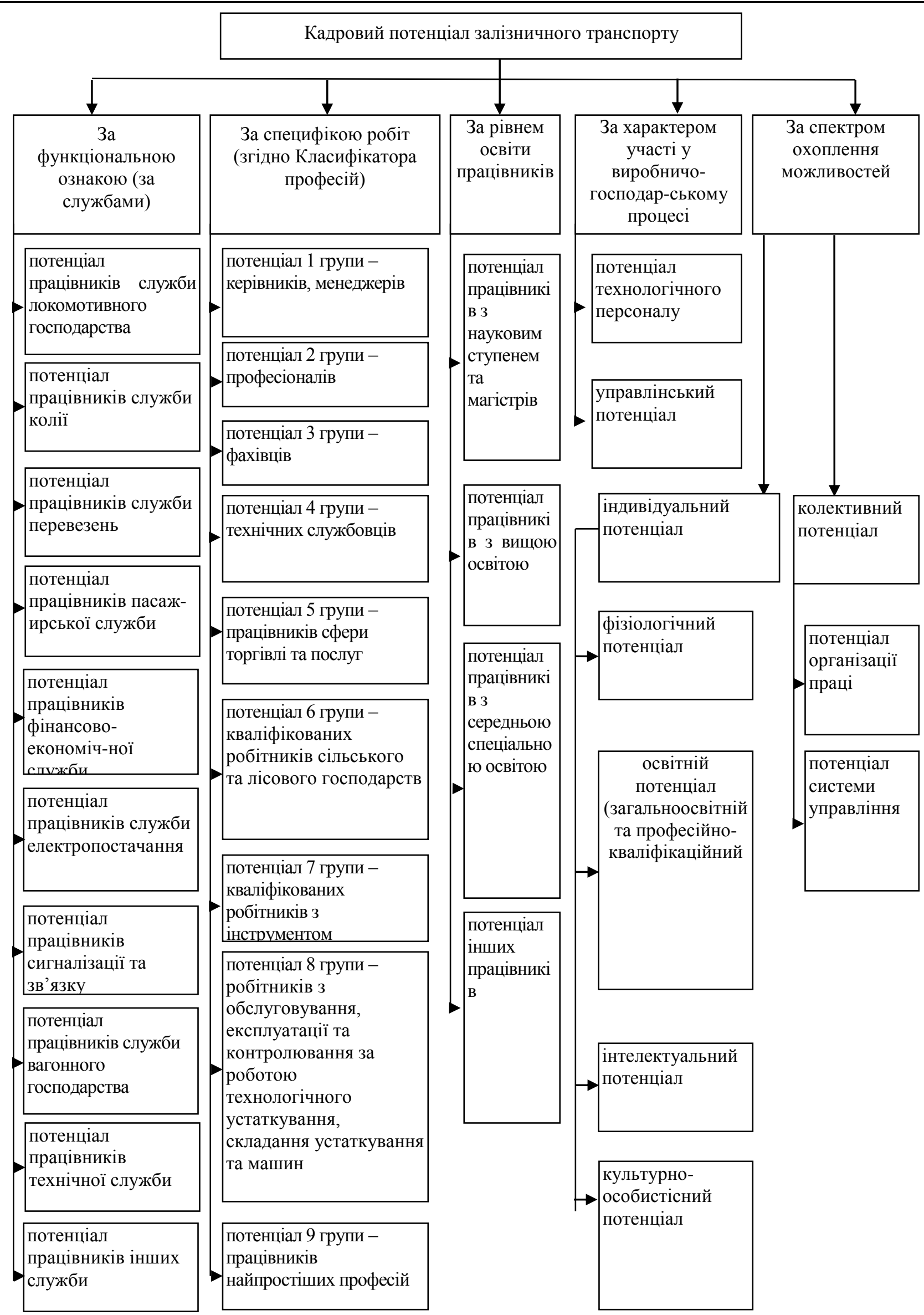

Рисунок 1 - Структура кадрового потенціалу залізничного транспорту 


\section{Список використаних джерел}

1. Назаренко І.Л. Оцінка та оптимізація кадрового потенціалу дирекції залізничного транспорту [Текст] / І.Л. Назаренко // Вісник економіки транспорту і промисловості. - №44. 2013. - C. 70 - 74.

2. Джаин И.О. Оценка трудового потенциала [Текст]: Монография. / И.О. Джаин. Сумы: МТД «Университетская книга», 2002. - 250 с.

3. Ким М.Н. Трудовой потенциал: формирование, использование, управление [Текст] / М.Н. Ким. Харьков: ХНУ, 2003. - 247 с.

4. Федонін О.С. Потенціал підприємства: формування та оцінка [Текст]: навч. посібник. / О.С. Федонін, І.М. Рєпіна, О.І. Олексюк. - К., КНЕУ, 2003. - 316 с.

5. Авдеенко В.Н. Производственный потенциал промышленного предприятия [Текст] / В.Н. Авдеенко, В.А. Котлов. - М.: Экономика, 1989. - 240 с.

6. Радько С.В. Оценка трудового потенциала с учетом рисков его управления [Текст] / С.В. Радько //Управление риском. - 2003. - №2. - С. 30 - 41.

7. Краснокугська Н.С. Потенціал підприємства: формування та оцінка: [Текст]: навчальний посібник. / Н.С. Краснокугська -К:: Центр навчальної літератури, 2005. -352 с.

8. Точенов И.В. К вопросу об оценке кадрового потенциала предприятия [Текст] / И.В. Точенов //Вісник Донбаської державної академії будівництва і архітектури. - 1999. - №5(19). - C. $69-71$.

9. Жулавський А.Ю. Принципи оцінки кадрового потенціалу промислових підприємств [Текст] / А.Ю.Жулавський, Є.В. Лапін. //Механізм регулювання економіки, економіка природокористування, економіка підприємства та організація виробництва. 2002. - №1-2. - С. 161 - 172.

10 Іванілов О.С. Нова експертно-бальна методика оцінки кадрового потенціалу підприємства [Текст] / О.С. Іванілов, І.Л. Плєтникова, Д.М. Дячков // Вісник економіки транспорту і промисловості. - №15-16. - 2006. - С. 67 - 74.

11. Познякова О. В. Сукупний потенціал залізничного транспорту [Електронний pecypc] / О. В. Познякова. - Режим доступу: http://nbuv.gov.ua/jpdf/Znpdetut_eiu_2013_25_17.pdf .

Рецензент д-р екон. наук, професор В.В.Компанієць

Погрібна Яна Дмитрівна, слухач НН ІППК Украӥнської державної академії залізничного транспорту, заст. нач. Договірного відділу служби матеріально-технічного забезпечення Донецької залізнииі,050-663-99-09

Pogribna Yana Dmytrivna, the listener of Educational-Scientific Institute of Ukrainian State Academy of Railway Transport, depchief of contractual department of the Donetsk railway, 050-663-99-09 
УДК 330.322.5

\title{
АНАЛІЗ МЕТОДИЧНИХ ПІДХОДІВ ДО ОЦІНКИ ЛЮДСЬКОГО КАПІТАЛУ ПІДПРИЕМСТВ
}

магістрант Ховрах О. М.

\section{АНАЛИЗ МЕТОДИЧЕСКИХ ПОДХОДОВ К ОЦЕНКЕ ЧЕЛОВЕЧЕСКОГО КАПИТАЛА ПРЕДПРИЯТИЙ}

магистрант Ховрах О. Н.

\section{ANALYSIS OF METHODOLOGICAL APPROACHES TO ASSESSING HUMAN CAPITAL OF ENTERPRISES}

\author{
master student Khovrakh O. N.
}

Стаття присвячена питанням оцінки людського капіталу на підприємствах. В роботі проаналізовано праџі науковичів з питань дослідження оцінки людського капіталу на сучасному етапі сочіально-економічного розвитку. Зроблено огляд актуальних підходів до оцінки людського капіталу, наведено їх недоліки. Визначено, щэо діагностика людського капіталу підприємств повинна носити комплексний характер.

Ключові слова: людський капітал, оцінка капітала, інвестиції, методи оцінки, нематеріальні активи.

Статья посвящена вопросам оценки человеческого капитала на предприятиях. В работе проанализированы труды ученых по исследованию оченки человеческого капитала на современном этапе сочиально-экономического развития. Сделан обзор актуальных подходов к оченке человеческого капитала, привеедень их недостатки. Определено, что диагностика человеческого капитала предприятий должна носить комплексный характер.

Ключевые слова: человеческий капитал, оценка капитала, инвестииии, методы оценки, нематериальные активы.

Article deals with evaluation of human capital in enterprises. Human capital as part of the intellectual capital of the organization and the investment in it, is a major factor in improving the competitiveness of enterprises. The growing role of human capital, in turn, determines the need for its measurement and economic evaluation as an important condition for improving the management of this resource. The article analyzes the works of scientists on research evaluation of human capital at the present stage of economic development. A review of current approaches to assessing human capital priveedeny their faults one universal method for estimating human capital can not be developed because the results of human activity is influenced by many different factors, not quantifiable. In connection with this assessment of human capital should be comprehensive and take into account the sectoral focus. The main objective of the organization's investment in human capital is that investments should increase productivity person or allow him after training to engage in labor, the result of which the company makes a profit. Diagnosis of human capital enterprises can serve as a basis for a general diagnosis of organizational development of the company and the basis for developing a strategy for further development of the enterprise.

Keywords: human capital, capital appreciation, investment, evaluation methods, intangible assets.

Постановка проблеми та ї̈ зв'язки 3 науковими чи практичними завданнями. Одним 3 вагомих факторів ефективного виробництва кожної компанії $є$ досягнення конкурентних переваг, в тому числі за рахунок розвитку нематеріальних активів, підвищення якості професіоналізму працівників, нарощування потенціалу 
працівників апарату управління. Реалізація цього процесу обумовлюється комплексним підходом до управління персоналом, оптимізації системи пошуку, підбору, залучення та утримання кваліфікаційних кадрів, підсилення мотивації персоналу.

Сьогодні дослідження проблем підвищення ефективності використання продуктивних сил людей, що реалізуються в сучасних умовах у формі людського капіталу, відноситься, до рангу першочергових завдань в структурі економічних досліджень і на підприємствах залізничного транспорту.

Зростаюча роль ЛК, в свою чергу, визначає необхідність його вимірювання та економічної оцінки, як важливої умови підвищення ефективності управління цим ресурсом. В умовах недосконалості ринку праці, і зокрема, галузевих особливостей залізничного транспорту інструменти економічної оцінки людського капіталу повинні дозволити підвищити якість прийнятих управлінських рішень щодо інвестицій в людський капітал.

Аналіз останніх досліджень $i$ публікацій та виділення невирішених частин загальної проблеми. Дослідженню різних аспектів оцінки людського капіталу приділяють увагу багато вітчизняних i зарубіжних авторів [1-10]. Серед науковців України доцільно відзначити увагою дослідження В. Диканя, О. Кірдіної, В. Компанієць, Н. Корольової, Н. Якименко, праці яких присвяченні розробці теоретичних основ i практичних рекомендацій з формування та розвитку ЛК підприємств транспорту [1-5].

Незважаючи на те, що проблемі оцінки праці в контексті теорії людського капіталу присвячені роботи багатьох учених, методи економічної оцінки людського капіталу на рівні підприємства залишаються недостатньо розробленими. Актуальність і практична значущість проблеми, iï недостатня наукова розробленість визначили вибір мети дослідження.

Mema cmammi полягає в дослідженні існуючих методичних підходів щодо оцінки людського капіталу підприємства.

\section{Виклад}

основного

матеріалу

дослідження.У науковій літературі є різні підходи до змісту поняття «людський капітал». Ряд вчених трактує людський капітал як те, чим володіє людина. Інші науковці розглядають людський капітал як те, що приносить їй прибуток. Третя група авторів розуміють під людським капіталом ресурс, який використовується організаціями (чи іншими інвесторами) для отримання свого доходу. При цьому таке різне тлумачення даного поняття дослідниками виникло через вирішення різних завдань, зумовлених аналізом економічних інтересів $\mathrm{i}$ потреб різних суб'єктів економічних відносин.

У загальному вигляді під людським капіталом розуміється запас знань, умінь, компетенцій, мотивацій і здоров'я людини, який використовується в тій чи іншій сфері виробництва. Такої концепції 3 різним ступенем доповнень дотримується більшість економістів, прямо або побічно приділівших увагу цій проблемі.

На нашу думку, людський капітал визначальний фактор виробництва, який являє собою накопичений людиною запас компетенцій, знань і особистісних навичок, втілених у здатності до творчої праці.

Людський капітал як складна економічна категорія має якісні та кількісні характеристики. В рамках сучасної теорії людського капіталу оцінюється не тільки обсяг вкладень в людський капітал, а й обсяг акумулюваного особистістю людського капіталу. Основними факторами і в той же час складовими людського капіталу $\epsilon$ не тільки знання, досвід, навички до певного виду діяльності, але i здоров'я, комунікабельність, діяльність, пов'язана із захистом екології, ментальність, ступінь включеності в духовне i соціальне виробництво, інтелектуальна активність [6].

3 поняттям соціального часу пов'язує людський капітал Б.В. Корнійчук [7]. Соціальний час - це час, протягом якого людина зайнята вищої діяльністю, він $\epsilon$ цільовим показником для людини в інформаційному суспільстві. Людина цінна для суспільства своєю реалізованої здатністю до розумової та духовної 
діяльності, до творчості. Чим сильніше розвинена ця здатність, тим більшою мірою він $\epsilon$ власне людиною. Реалізовану здатність до вищої діяльності, мислення, творчості Б.В. Корнійчук i називає людським капіталом. Автор пропонує свою методику розрахунку людського капіталу. Грунтується вона на методі геометричного уявлення капіталу.

Розглянемо ще деякі підходи науковців до оцінювання людського капіталу підприємства.

Пєтухова Т.О. пропонує методичний підхід до вартісної оцінки людського капіталу, характерною рисою якого $\epsilon$ визначення його цінності, яка виміряються за допомогою ідентифікації, систематизації та модифікації витрат у людський капітал підприємств залізничного транспорту [8].

Основою методичного підходу $\mathrm{H}$. Якименко є загальна методологія визначення індексу розвитку людського капіталу, який є складним індексом, що визначає рівень середніх досягнень за трьома основними напрямками в галузі розвитку людського потенціалу - здоров'я та довголіття, знання та гідного життєвого рівня [5, с. 207].

Н. Корольова пропонує методичний підхід до оцінки ефективності розбудови науково-освітнього та творчого сектору підприємств залізничного транспорту, що проводиться за підсумком діяльності Центру навчально-наукового та інноваційного розвитку та показниками, що згруповані за критеріями: інноваційного розвитку, ефективності освіти, виховання та навчально-професійного розвитку [4].

Покусаєвим О.M. запропонована методика економічної оцінки витрат на підготовку спеціалістів в вузі методом скорочення непрямих витрат студента, пов'язаних 3 навчанням, за рахунок впровадження дистанційних технологій; підвищення ефективності використання вільного часу студента за рахунок здобуття ним другої або додаткової освіти; використання гнучкого учбового графіку, що дозволяє студентові поєднувати навчання i роботу за фахом, компенсуючи, таким чином, втрачені заробітки [9].
Серед методів оцінки людського капіталу організації найбільше поширення в економічній літературі мають такі $[3,5,10]$ :

1) методи якісної оцінки (експертний підхід). Вони включають в себе оцінку якісних характеристик конкретних працівників, а також оцінку трудового внеску працівників в прибуток компаніi. К якісним характеристикам працівника можна віднести такі показники як: рівень освіти, трудовий стаж, розряд, здатність до нестандартного мислення та ін.

При експертному підході проводиться оцінка як конкретних працівників, так i всього персоналу. Надалі проводиться визначення ключових показників, що визначають внесок співробітників в успішну діяльність компаній. Після встановлюється коефіцієнт значущості для кожного 3 показників і визначається бальна оцінка кожного показника.

Експертний метод найбільш об'єктивно оцінює якісні складові людського капіталу, проте, за думкою фахівців, обмеження тільки даним методом не дозволяє отримати вартісний вимір людського капіталу через неможливість переходу від якісних показників до кількісних. Крім того, відсутність стовідсоткової впевненості в достовірності отриманих оцінок знижують його ефективність;

2) оцінка людського капіталу, виходячи 3 спрямованих інвестицій (витратний підхід). Згідно даного підходу сума витрат в освіту, перепідготовку працівників компанії розглядається як довгострокові інвестиції в капітал знань даного підприємства. Однак інвестиції в людський капітал $\epsilon$ виправданими, коли простежується тенденція підвищення ефективності діяльності компанії i пролежувати внесок конкретного співробітника в даній тенденції. Результатом інвестицій в людський капітал слід вважати підвищення продуктивності праці.

До основних недоліків методу відноситься складність визначення питомої ваги ефективності конкретного працівника в загальному фінансовому результаті компанії, 
проблема об'єктивного розрахунку усіх інвестицій в людський капітал;

3) оцінка людського капіталу за аналогією 3 фізичним капіталом. Між фізичним та людським капіталом $є$ певні подібності (обидва капітали приймають участь в процесі господарської діяльності компанії, формують кінцеві фінансові результати, знецінюються 3 часом). Це дозволяє провести оцінку людського капіталу за аналогією з фізичним.

Недоліками такого підходу $\epsilon$ складність об'єктивної оцінки первісної вартості, визначення терміну роботи конкретного співробітника в компанії, а також складність ведення обліку;

4) оцінка людського капіталу за допомогою індексів. Цей підхід дозволяє долати обмеження при використанні натуральних i вартісних оцінок. Однак застосування цього методу вимагає вирішення питання про те, які саме витрати на індивідуальному рівні, рівні фірми i макрорівні слід розглядати як інвестиції.

Проведений аналіз підходів до оцінювання людського капіталу дозволив зробити наступні висновки.

По-перше, оцінка людського капіталу в тій чи іншій мірі сконцентрована на оцінці вартості людського капіталу організації та/ або на оцінці віддачі від вкладених спрямованих інвестицій (включаючи витрати на навчання) в людський капітал організації. Вимірявши вплив, який чинять співробітники організації на іiі фінансові показники, керівництво може оцінювати i розвивати можливості співробітників 3 метою досягнення більш вагомих результатів відбиваються у фінансових показниках компанії.
По-друге, оцінка людського капіталу може служити діагностичним інструментом для компанії. Але в цілому підприємства розглядають людського капіталу як ресурс для отримання свого доходу.

Основна мета спрямованих інвестицій організації в людський капітал, включаючи витрати на навчання, полягає в тому, що інвестиції повинні або підвищувати продуктивність праці людини, або дозволяти їй після проходження навчання займатися працею, результат якої приносить прибуток компанії.

Висновки. Людський капітал як складова частина інтелектуального капіталу організації та інвестиції в нього, є одним 3 основних факторів підвищення конкурентоспроможності підприємства. Єдиний універсальний метод оцінки людського капіталу неможливо розробити, оскільки на результати діяльності людини впливає величезна кількість різноманітних факторів, що не піддаються кількісній оцінці. У зв'язку з цим оцінка людського капіталу повинна носити комплексний характер та враховувати галузеву спрямованість.

Діагностика людського капіталу підприємств може бути не тільки аналітичним інструментарієм для оцінювання процесів формування і використання людського капіталу, а й в комплексі з іншими показниками служити основою для загальної діагностики організаційного розвитку підприємства та підгрунтям для розробки стратегії подальшого розвитку суб'єкта господарювання.

\section{Список використаних джерел}

1 Дикань, В.Л. Ефективність роботи транспортної системи України в умовах глобалізації економічних систем [Текст] / В.Л. Дикань // Вісник економіки транспорту і промисловості. - 2011. - №33. -С. 13-19.

2 Кірдіна, О.Г. Завдання системи управління людським капіталом підприємства [Текст] / О.Г. Кірдіна // Вісник економіки транспорту і промисловості. - 2013. - № 42. C.375-378.

3 Компанієць, В.В. Методологічні підходи до управління людським капіталом на залізничному транспорті [Текст] / В.В. Компанієць, С.М. Лисенко // Збірник наукових праць 
Північно - Східного Наукового Центру Транспортної Академії України. - 2008. - Вип. 93. C. 31-34.

4 Корольова, Н.М. Розвиток людського капіталу підприємств залізничного транспорту [Текст]: автореф. дис. ... канд. екон. наук: 08.00.04 / Корольова Наталія Миколаївна. - Х., 2010. - 19 c.

5 Якименко, Н.В. Методичний підхід до оцінки людського капіталу як умови забезпечення економічного зростання залізничного транспорту України [Текст] / Н.В. Якименко //Маркетинг і менеджмент інновацій.- 2012, -№ 3.- С.206-211.

6 Калина, А.В. Підвищення ефективності регіональних інноваційних систем шляхом формування і розвитку людського капіталу [Текст] / А.В. Калина // Соціально-трудові відносини: теорія та практика: зб. наук. праць. - К. : КНЕУ ім.. В. Гетьмана, 2011. -№ 1. - С. 47-50.

7 Корнейчук, Б.В. Человеческий капитал во временном измерении [Текст]/ Б.В. Корнейчук. - СПб.: Изд-во СПбГПУ, 2003. - 91 с.

8 Пєтухова, Т.О. Оцінка людського капіталу підприємств залізничного транспорту [Текст]: автореф. дис. ... канд. екон. наук: 08.00.04 / Пєтухова Тетяна Олександрівна. - Х., 2011. $-21 \mathrm{c}$.

9 Покусаев, О.Н. Экономическая оценка человеческого капитала транспортной компании: [Текст]: автореф. дисс. ... канд. экон. наук: 08.00.05 / Олег Николаевич Покусаев - М., 2013. - 31 c.

10 Шихвердиев, А.П. Управление человеческим капиталом как фактор обеспечения корпоративной безопасности предприятия [Текст]/ А.П. Шихвердиев - Сыктывкар: Изд-во СыктГУ, 2012. - 136 с.

Рецензент д-р екон. наук, професор О.Г.Кірдіна

Ховрах Ольга Миколаївна, слухач НН ІППК Украӥнської державної академії залізничного транспорту, економіст фінансово-економічного відділу Знам'янської дирекції залізничних перевезень Одеської залізниці, 050635-77-98, e-mail: Olga_nik_may@mail.ru.

Khovrakh Olga Nikolaevna, the listener NN Institute of Ukrainian state Academy of railway transport, economist financial and economic department Znamenskaia management of rail transportation Odessa railway, 050 635-77-98, e-mail: Olga_nik_may@mail.ru.

УДК:658.7:656.2

\title{
КЛАСИЧНІ ТА НЕТРАДІЦЙНІ ШЛЯХІ ЗНИЖЕННЯ ВИТРАТ ПІДПРИЕМСТВ ЗАЛІЗНИЧНОГО ТРАНСПОРТУ
}

магістрант В.О. Сорока

\section{КЛАСИЧЕСКИЕ И НЕТРАДИЦИОННЫЕ ПУТИ СНИЖЕНИЯ РАСХОДОВ ПРЕДПРИЯТИЙ ЖЕЛЕЗНОДОРОЖНОГО ТРАНСПОРТА}

\author{
магистрант В.А. Сорока
}

\section{CLASSIC AND INNOVATIVE WAYS TO REDUCE COSTS OF RAILWAY TRANSPORT}

\author{
master student V.A. Soroka
}

У статті проведено аналіз сучасних иляхів зниження витрат на вітчизняних підприємствах. Зазначено вплив обсягу та структури витрат на конкурентоспроможність підприємства. Досліджено основні напрями скорочення витрат на підприємствах транспорту. Зроблено висновок щэодо доцільності скорочення саме паливно-енергетичних витрат підприємств транспорту. 
Ключові слова: витрати підприємства, екстенсивні резерви зниження витрат, інтенсивні резерви зниження витрат, ресурсозберігаючі технології, організаційні заходи, організаційно-технічні заходи.

В статье проведен анализ современных путей снижения расходов на отечественных предприятиях. Указано влияние объема и структуры расходов на конкурентоспособность предприятия. Исследовань основные направления сокращения затрат на предприятиях транспорта. Сделан вывод о иелесообразности сокращения именно энергетических затрат предприятий транспорта.

Ключевые слова: расходы предприятия, экстенсивные резервы снижения расходов, интенсивные резервы сокращения расходов, ресурсосберегающие технологи, организационные мероприятия, организационно-технические мероприятия.

The article analyzes the modern ways to reduce the cost of domestic enterprises. Given the impact of the volume and cost structure on the competitiveness of enterprises. The basic direction of reducing the costs of Transportation. It was concluded that the feasibility of reducing energy costs is transport enterprises.

Keywords: costs of the company, extensive reserves to reduce costs, intensive reserves to reduce the cost, resource-saving technologies, institutional arrangements, organizational and technical measures.

Постановка проблеми та її зв'язки 3 науковими чи практичними завданнями. Сучасне підприємство, якщо воно бажає отримувати постійно зростаючий прибуток, повинне виважено та обгрунтовано відноситися до своїх ресурсів. Успіх у конкурентної боротьбі залежить від здібності управлінського апарату підприємства вміло управляти своїми витратами. Цей процес передбачає постійний аналіз витрат, вивчання чинників, які впливають на їх рівень та динаміку, визначати залежність між витратами, обсягом реалізації, ціною і прибутком підприємства, а також здійснювати пошук можливостей максимізації прибутку шляхом вибору найвигіднішого поєднання змінних та постійних витрат.

Аналіз останніх досліджень і публікацій та виділення невирішених частин загальної проблеми. Розробка заходів щодо зниження витрат підприємства залишається актуальним об'єктом дослідження як науковців так і практиків. Актуальними $є$ питання визначення сутності витрат, їх класифікації та обліку. Цим питанням присвячені роботи Н. А. Каморджанова, И. В. Карташова [1].

Багато вчених приділяють увагу вивченню залежності структури витрат та ефективності діяльності підприємства. Якщо частка заробітної плати зменшується, а частка амортизації збільшується, то це свідчить про підвищення технічного рівня підприємства, про ріст продуктивності праці. Питома вага заробітної плати скорочується i в тому випадку, якщо збільшується частка виконуваних комплектуючих виробів, напівфабрикатів, що свідчить про підвищення рівня кооперації і спеціалізації виробництва. Велика кількість робіт присвячено пошуку резервів скорочення витрат підприємства. Це глобальне питання, яке актуально для усіх галузей економіки [2].

Метою статті $\epsilon$ узагальнення існуючих шляхів зниження витрат підприємства та вибір тих, що у сучасних умовах господарювання більш результативні. Виклад основного матеріалу дослідження. Головним напрямком аналізу резервів зниження собівартості продукції $\epsilon$ дослідження складу кожного елемента витрат, виявлення причин їх росту та шляхів зниження. За своєю суттю резерві зниження витрат можуть бути: організаційнотехнологічні, технічні, соціальні. Кожна із груп може мати екстенсивний напрямок або інтенсивний напрямок.

На залізничному транспорті до екстенсивних шляхів зниження витрат підприємства можливо віднести наступні: відміна нерентабельних перевезень, зміна 
складу вантажних та пасажирських поїздів; зміна асортименту послуг, що надаються клієнтові; скорочення персоналу підприємства [3].

Самим простим шляхом скорочення витрат є зменшення обсягу робіт. Але 3 іншого боку, діє інша погроза - перехід споживачів до конкурентів. Слід пам'ятати, що в деяких випадках обсяг виробництва може виконувати протилежну роль по відношенню до витрат підприємства. Йдеться про так званий ефект масштабу. Нині економія на масштабах виробництва стала, по суті, найважливішим чинником конкурентоспроможності великих фірм, особливо в наукомістких галузях.

Біля 73\% загального об'єму торгівлі країн $\mathrm{EC} \mathrm{легковими} \mathrm{автомобілями,}$ вантажівками, побутовою електронікою мотивується різницею у витратах, обумовленою відмінностями в масштабах виробництва [4].

Передові компанії світу активно використовують практику скорочення первинних природних ресурсів. Так, в довгостроковій стратегіï стабільного розвитку компанії "L'Oreal" головна увага приділена необхідності 50 \%-вого скорочення викидів вуглецю в атмосферу i споживання води. Дотримуючись вказаної стратегіï, компанія в 2005-2011 роки скоротила викиди вуглецю в атмосферу на $30 \%$ і використання води на $23 \%$.

Необхідно пам'ятати: щоб зберегти одну тону умовного палива (7000 ккал) шляхом застосування нової технології, потрібно в 3-4 рази менше витрат у порівнянні 3 витратами на видобуток такого ж обсягу палива.

\begin{tabular}{|c|c|c|}
\hline До & інтенсивних & Зниження \\
\hline витрат & підприємства & відносяться: \\
\hline застосування & сучасних & технологічних \\
\hline
\end{tabular}
поліпшеними якісними характеристиками; використання вторинної сировини, активізація процесів рекуперації енергії; механізація та автоматизація виробничих процесів; підвищення кваліфікації працівників та продуктивності праці; застосування моральної та матеріальної мотивації працівників.
Використання нових технологій відбувається в усіх галузях економіки. Так, будівництво будинків 3 газобетону у Башкортостані (Росія) в 2014 році дозволило понизити собівартість будівництва на 30 \%.

Після з'єднання Західної і Східної

Німеччини там сталася справжня термоізоляційна революція. Уряд створив державну Програму енергозбереження. I ось за рахунок утеплення фасадів будівель, заміни віконних блоків, ремонту дахів котельних i тому подібному країна вже через три роки зменшила імпорт енергоресурсів (80\%) в два рази.

Пробні варіанти "техніки 3 мізками" вже існують i через декілька років, як передбачають експерти, увійде до комплекту сервісу, який стає все популярніше. Це так званий "розумний будинок". На відміну від звичайного в розумному будинку пов'язані воєдино системи опалювання, кондиціонування, відеоспостереження, освітлення i безпеки. За підрахунками фахівців, управління кліматом у такому будинку зменшує витрату енергії в середньому на 10\%, а електропостачанням на 3 - 5\%. Витрати на експлуатацію інженерних систем подають в три 3 половиною рази, і будівля здатна разу в півтора довше протягнути без капітального ремонту. Ризик пожежі, потопу i iнших неприємностей у нього значно нижче, ніж у сусідів, так, що знижуються i виплати страховикам.

Ресурсозберігаючі технології широко застосовуються на залізничному транспорті. Нова техніка дозволяє знижувати експлуатаційні витрати не тільки в тих господарствах, де вона вводиться, але й - у суміжних господарствах. Так, при електричній тязі прискорення обороту й збільшення середньодобового пробігу вантажного вагона в порівнянні 3 тепловозною тягою викликає відносне скорочення вагонного парку й, отже витрат 3 ремонту вагонів. Підвищення маси й збільшення швидкостей руху поїздів сприяє зниженню необхідної пропускної здатності ділянок, зменшенню необхідної кількості роздільних пунктів. 
Наведемо ще один приклад впливу технологій на витрати підприємства транспорту. Одним з ефективних механізмів захисту індивідуального та комерційного транспорту $є$ система супутникового моніторингу легкових, вантажних автомобілів та інших транспортних засобів від компанії Benish GPS Ukraine. Система супутникового моніторингу легкового та вантажного автотранспорту контролює розташування, швидкість руху, витрату палива, пройдену відстань. Інформація передається по каналу GPS/GSM і завдяки цьому $\epsilon$ можливість здійснювати GPSмоніторинг пересування транспорту 24 години на добу через мережу Інтернет.

Зменшенню експлуатаційних витрат сприяють організаційні заходи. У вітчизняній практиці в цілях реалізації організаційних заходів по зниженню витрат доцільно: закривати низькорентабельні або збиткові допоміжні виробництва; згортати морально застарілі і економічно небезпечні виробництва; розробляти державну програму створення технічних нововведень; створювати спільні підприємства, у тому числі із зарубіжними компаніями; залучати кошти державних i недержавних фондів; переробити систему оплати праці наукових кадрів; брати активну участь в міжнародних виставках, семінарах і так далі [5].

Організаційні заходи щодо зниження витрат активно використовуються на залізничному транспорті. Так, деякі дільничні станції перетворюються в проміжні, скорочується кількість пунктів технічного обслуговування вагонів і т.д. У результаті здійснення зазначених заходів, зменшуються експлуатаційні витрати не тільки в локомотивному господарстві, але й у господарствах перевезень, вагонному й інших господарствах.

Велике значення у напрямку зниження витрат мають організаційнотехнічні заходи. Так, в металургії, впровадження конверторного і електродуги способів виплавки сталі знижує витрати енергії на $27 \%$ і підвищує продуктивність виробництва в порівнянні 3 мартенівськими в 2-3 рази. Установки для безперебійного розливу сталі економлять до 15-20 \% металу.
На залізничному транспорті організаційнотехнічні заходи здійснюються в напрямку скорочення витрат на паливо та електроенергію. За статистичними даними за один рік залізничний транспорт споживає біля 6 млрд. кіловат-годин електроенергії (3 них понад 4,5 млрд. кіловат-годи на електротягу). Загалом витрати електроенергії на долю електричного транспорту (включаючи залізничний, міський i промисловий) припадає біля $8 \%$ від загального електроспоживання в Україні.

В системі електропостачання електротранспорту промислових підприємств, як правило використовується централізоване живлення контактної мережі від однієї тягової підстанції з одностороннім живленням. Проте, використання зворотного живлення тягової мережі дозволяє значно зменшити витрати електроенергії. Так, якщо на дільниці знаходиться один поїзд, то витрати зменшуються в 2 рази; якщо на відрізку зростає числу поїздів (до безмежності), то ці витрати будуть постійно зрівнюватися і при збільшенні до 6 і більше стають однаковими. Тому 3 точки зору економії електроенергії при невеликій кількості поїздів на дільниці слід здійснювати двостороннє живлення дільниці тягової мережі.

На тягових підстанціях бажано підтримувати постійну напругу живлення перетворюючих агрегатів. В ряді випадків підвищують напругу живлення в залежності від зростання тягової мережі. Для цього використовують або автотрансформатори, включені на вході трансформаторів перетворюючих агрегатів, або понижуючі трансформатори з РПН.

Крім цього існують додаткові заходи енергозбереження на залізничному транспорті: скорочення кількості затримок поїздів перед світлофорами, впровадження економічних світильників, заміни зношеного контактного проводу, відключення освітлення платформ при відсутності зупинок поїздів в нічні години, зниження витрат на власні потреби тягових підстанцій та ряд інших традиційних шляхів енергозбереження [6]. 


\section{Рекомендується}

впровадження режимних карт та оптимальних графіків руху поїздів в залежності від вантажопасажирських навантажень ліній iз максимальним зменшенням маневрових робіт. Відповідність режиму ведення поїзда оптимальному режимові для окремої дільниці залежить від майстерності та кваліфікації машиністів, але значну роль може відіграти автоматизація. За рахунок впровадження у депо програмних комплексів розрахунку режиму ведення поїздів (приклад депо міста Києва) дозволяє скоротити витрати ПЕР на тягу в середньому на 5 \%.

Зниження на $1,8 \%$ порожнього пробігу вагонів до загального пробігу в вантажному русі зменшує питомі витрати електроенергії на $0,45 \%$, або скорочує на 0,3 $\%$ загальну енергоємність перевезень. Зниження одиночного пробігу лише електропоїздів (одиночне слідування, подвійна тяга, підштовхування) на $1 \%$ знижує питомі витрати електроенергії на $0,24 \%$. Зниження простоїв електровозів в робочому стані на $1 \%$ знижує питомі витрати електроенергії на 0,6 \%.

Для залізничного транспорту одним 3 напрямів скорочення енерговитрат $\epsilon$ зниження маси рухомого складу, головним чином вагонів. В середньому маса тари вантажного вагону інвентарного парку становить 23 тони. Найбільш ефективним шляхом зниження маси $\epsilon$ застосування алюмінієвих сплавок як конструкційних матеріалів для вантажних вагонів, використання вантажних вагонів 3 параболічним дном. Зменшенню маси тари вантажного вагону лише на 500 кг (2 \%) рівнозначне зниженню енергоємності перевезень на 0,3\%.

Збільшення статичного навантаження на вагон зменшує питому вагу тари в перевізної роботі, а тому безпосередньо впливає на іiі енергоємність. Збільшення статичного навантаження на 1 тону рівнозначне зниженню енергоємності перевезень на 0,5\%.

$$
\text { Широко }
$$

використовувати

рекомендується гальмування. При пересуванні поїздів на вибіг (без

навантаження)

тягові електродвигуни електропоїздів працюють генераторами та віддають вироблену ними енергію у контактну мережу. Енергія рекуперації також може бути перетворена на тягових підстанціях в енергію змінного струму і повернена в електромережу. Однак при цьому на підстанціях необхідно встановлювати додаткові інвенторні установки. Дослідження тижневого графіка витрат електроенергї вказали, що в системах приміського сполучення в середньому до 70 \% енергії рекуперації використовується іншими поїздами, а решта 30 \% втрачається. Для того, щоб енергію рекуперації використовувати в мережах постійного струму на підстанціях встановлюють спеціальні стичні перетворювачі для повернення енергії в трьохфазну мережу.

Передбачається, що модернізація системи електропостачання пасажирських вагонів, в залежності від природних умов, також дозволить скоротити споживання електроенергії на залізничному транспорті. Автоматизація систем охолодження електричних машин електровозів ВЛ-80 дозволить зменшити витрати на охолодження машин (такі витрати сягають $15 \%$ електроенергії на загальну тягу) на 5-7 \%. Загальний потенціал економії електроенергї при модернізації всіх електровозів ВЛ-80 становить 162,4 млн. кіловат-годин на рік, або 3,6 \% від загальних витрат електроенергї [6].

На провідних вітчизняних підприємствах у останній час активізується використання нових матеріалів, вторинне використання матеріальних ресурсів, підвищення надійності й зносостійкості технічних засобів та інші заходи. Значною мірою використання вторинної сировини грунтується на позитивному досвіді розвинених країн. Сьогодні в Німеччині 3 металобрухту виплавляється близько 75\% стали, а найближчим часом в усіх країнах $Є C$ планується добувати усю сталь 3 металобрухту, оскільки тонна такої сталі в 712 разів дешевше по отриманню $з$ первинної сировини - залізної руди [7].

Досвід Німеччини слід зазначити і в частині розвитку залізничного транспорту. 
Так, в країні ведеться переробка старого щебеневого баласту 3 його подальшим повторним використанням при ремонті шляху. При цьому дуже строго регламентовані вимоги до якості баласту, його гранулометричного складу, порядок приймання щебеню від підприємств, що виробляють очищення.

Вирішальний вплив на зниження собівартості робіт виявляє підвищення продуктивності праці. Ріст продуктивності праці викликає відносне

зменшення необхідного контингенту працівників i фонду оплати праці.

Таким

чином,

вітчизняні підприємства залізничної галузі мають великий досвід у скороченні витрат, який разом з використанням закордонного досвіду дає великий результат. Скорочення витрат, у в першу чергу, позитивно відображається на фінансовому становище залізниць.

\section{Список використаних джерел}

1 Каморджанова Н.А. Бухгалтерский финансовый учет [Текст] / Н. А. Каморджанова, И. В. Карташова - СПб.: Питер, 2008. - 480 с.

2 Дикань В. Л. Экономика предприятия [Текст]: учеб. пособие / В. Л. Дикань, Е.В. Шраменко, Н. В. Якименко. - Харьков: УкрГАЖТ, 2008. - 274 с.

3 Манів 3.О. Економіка підприємства. [Текст]: навч. посіб. / З. О. Манів. - К.: Знання, 2004. $-580 \mathrm{c}$.

4 Подольский В. И. Аудит [Текст]: Учебник для вузов / В. И. Подольский, А. А. Савин, Л. В. Сотникова и др. / под ред. Проф. В. И. Подольского. - 6-е изд., перераб. и доп. М. : ЮНИТИ-ДАНА, Аудит, 2006. - 589 с.

5 Грушко В. Фінансова безпека бізнесу: податковий аспект / В. Грушко, С. Лаптев, Л. Кошембар. - К.: Університет економіки і права “Крок”, 2010. - 256 с.

6 Підвищення ефективності використання електроенергії [Електронний ресурс]: Электронный журнал энергосервисной компании "Экологические системы” - 2003 - № 11 (23).-Режим доступу: http://esco-ecosys.narod.rv/2003_11art80.htm

7. Вечканов Г. С. Экономическая безопасность [Текст] / Г. С. Вечканов. - СПБ: Питер, 2007. $-384 \mathrm{c}$.

Сорока Валерій Олександрович, магістрант Тел. (063) 871-29-55

Soroka Valeriy Oleksandrovich, Master's student Tel. (063) 871-29-55 